Review

\title{
Space Probes
}

\author{
Relly Victoria Virgil Petrescu
}

ARoTMM-IFToMM, Bucharest Polytechnic University, Bucharest, (CE), Romania

\author{
Article history \\ Received: 29-04-2019 \\ Revised: $10-05-2019$ \\ Accepted: 20-05-2019 \\ E-mail: rvvpetrescu@gmail.com
}

\begin{abstract}
A space probe is an unmanned space vehicle launched into space to study more or less distant different celestial objects: The Sun, the planets, dwarf planets and small bodies, their satellites, the interplanetary medium or the interstellar medium. A space probe is distinguished from other unmanned spacecraft that remain in Earth orbit. Space probes can take a large number of forms to fulfill their mission: Orbiter placed in orbit around the observed celestial body, lander who explores in situ the soil of the target planet, impactor, etc. A probe can carry autonomous devices to increase its field of investigation: Sub-satellite, impactor, rover, balloon. A space probe has to travel great distances and operate far from the Earth and the Sun, which requires specific equipment. It must have enough energy to operate in regions where solar radiation provides only limited power, have a great autonomy of decision because the remoteness of the control center no longer allows human operators to react in real time at events, solving telecommunication problems made difficult by distances that reduce flow and resist radiation and extreme temperatures that malfude embedded electronics and mechanisms. Finally, to reach a destination at a cost and within an acceptable time, the spacecraft is led to use sophisticated methods of navigation and propulsion: Gravitational assistance, airbrake, ion propulsion. The first space probes are the Luna probes launched to the moon by the Soviet Union in 1959. In 1961, the Soviet Union launched Venera, the first probe to study another planet than the Earth, in this case, Venus. Russia, which was a leader at the beginning of the space age, has not had an active role since 1988 and left this place in the United States. The European Space Agency (Mars Express, Venus Express, Rosetta, participation in the Cassini-Huygens spacecraft) and Japan (Hayabusa, SELENE) are also becoming increasingly important. Finally, since the end of the 2000s, China and India have also been producing space probes. To offset a high development cost (an amount that can exceed one billion euros), the realization of space probes is now often the subject of international cooperation.
\end{abstract}

Keywords: Robots, Mechatronic Systems, Machines, Space, Space Probes

\section{Introduction}

A space probe is an unmanned space vehicle launched into space to study more or less distant different celestial objects: The Sun, the planets, dwarf planets and small bodies, their satellites, the interplanetary medium or the interstellar medium. A space probe is distinguished from other unmanned spacecraft that remain in Earth orbit. Space probes can take a large number of forms to fulfill their mission: Orbiter placed in orbit around the observed celestial body, lander who explores in situ the soil of the target planet, impactor, etc. A probe can carry autonomous devices to increase its field of investigation: Subsatellite, impactor, rover, balloon.

A space probe has to travel great distances and operate far from the Earth and the Sun, which requires specific equipment. It must have enough energy to operate in regions where solar radiation provides only limited power, have a great autonomy of decision because the remoteness of the control center no longer allows human operators to react in real time at events, solving telecommunication problems made difficult by distances that reduce flow and resist radiation and 
extreme temperatures that malfude embedded electronics and mechanisms. Finally, to reach a destination at a cost and within an acceptable time, the spacecraft is led to use sophisticated methods of navigation and propulsion: Gravitational assistance, airbrake, ion propulsion.

The first space probes are the Luna probes launched to the moon by the Soviet Union in 1959. In 1961, the Soviet Union launched Venera, the first probe to study another planet than the Earth, in this case, Venus. Russia, which was a leader at the beginning of the space age, has not had an active role since 1988 and left this place in the United States. The European Space Agency (Mars Express, Venus Express, Rosetta, participation in the Cassini-Huygens spacecraft) and Japan (Hayabusa, SELENE) are also becoming increasingly important. Finally, since the end of the 2000s, China and India have also been producing space probes. To offset a high development cost (an amount that can exceed one billion euros), the realization of space probes is now often the subject of international cooperation (Rulkov et al., 2016; Agarwala, 2016; Babayemi, 2016; Gusti and Semin, 2016; Mohamed et al., 2016; Wessels and Raad, 2016; Maraveas et al., 2015; Khalil, 2015; Rhode-Barbarigos et al., 2015; Takeuchi et al., 2015; Li et al., 2015; Vernardos and Gantes, 2015; Bourahla and Blakeborough, 2015; Stavridou et al., 2015; Ong et al., 2015; Dixit and Pal, 2015; Rajput et al., 2016; Rea and Ottaviano, 2016; Zurfi and Zhang, 2016a; 2016b; Zheng and Li, 2016; Buonomano et al., 2016a; 2016b; Faizal et al., 2016; Cataldo, 2006; Ascione et al., 2016; Elmeddahi et al., 2016; Calise et al., 2016; Morse et al., 2016; Abouobaida, 2016; Rohit and Dixit, 2016; Kazakov et al., 2016; Alwetaishi, 2016; Riccio et al., 2016 a-b; Iqbal, 2016; Hasan and El-Naas, 2016; Al-Hasan and AlGhamdi, 2016; Jiang et al., 2016; Sepúlveda, 2016; Martins et al., 2016; Pisello et al., 2016; Jarahi, 2016; Mondal et al., 2016; Mansour, 2016; Al Qadi et al., 2016b; Campo et al., 2016; Samantaray et al., 2016; Malomar et al., 2016; Rich and Badar, 2016; Hirun, 2016; Bucinell, 2016; Nabilou, 2016b; Barone et al., 2016; Chisari and Bedon, 2016; Bedon and Louter, 2016; Santos and Bedon, 2016; Minghini et al., 2016; Bedon, 2016; Jafari et al., 2016; Chiozzi et al., 2016; Orlando and Benvenuti, 2016; Wang and Yagi, 2016; Obaiys et al., 2016; Ahmed et al., 2016; Jauhari et al., 2016; Syahrullah and Sinaga, 2016; Shanmugam, 2016; Jaber and Bicker, 2016; Wang et al., 2016; Moubarek and Gharsallah, 2016; Amani, 2016; Shruti, 2016; Pérezde León et al., 2016; Mohseni and Tsavdaridis, 2016; Abu-Lebdeh et al., 2016; Serebrennikov et al., 2016; Budak et al., 2016; Augustine et al., 2016; Jarahi and Seifilaleh, 2016; Nabilou, 2016a; You et al., 2016; Al Qadi et al., 2016a; Rama et al., 2016; Sallami et al., 2016; Huang et al., 2016; Ali et al., 2016; Kamble and Kumar, 2016; Saikia and Karak, 2016; Zeferino et al.,
2016; Pravettoni et al., 2016; Bedon and Amadio, 2016; Chen and Xu, 2016; Mavukkandy et al., 2016; Gruener, 2006; Yeargin et al., 2016; Madani and Dababneh, 2016; Alhasanat et al., 2016; Elliott et al., 2016; Suarez et al., 2016; Kuli et al., 2016; Waters et al., 2016; Montgomery et al., 2016; Lamarre et al., 2016; Daud et al., 2008; Taher et al., 2008; Zulkifli et al., 2008; Pourmahmoud, 2008; Pannirselvam et al., 2008; $\mathrm{Ng}$ et al., 2008; El-Tous, 2008; Akhesmeh et al., 2008; Nachiengtai et al., 2008; Moezi et al., 2008; Boucetta, 2008; Darabi et al., 2008; Semin and Bakar, 2008; Al-Abbas, 2009; Abdullah et al., 2009; Abu-Ein, 2009; Opafunso et al., 2009; Semin et al., 2009a; 2009b; 2009c; Zulkifli et al., 2009; Marzuki et al., 2015; Bier and Mostafavi, 2015; Momta et al., 2015; Farokhi and Gordini, 2015; Khalifa et al., 2015; Yang and Lin, 2015; Chang et al., 2015; Demetriou et al., 2015; Rajupillai et al., 2015; Sylvester et al., 2015; Ab-Rahman et al., 2009; Abdullah and Halim, 2009; Zotos and Costopoulos, 2009; Feraga et al., 2009; Bakar et al., 2009; Cardu et al., 2009; Bolonkin, 2009a; 2009b; Nandhakumar et al., 2009; Odeh et al., 2009; Lubis et al., 2009; Fathallah and Bakar, 2009; Marghany and Hashim, 2009; Kwon et al., 2010; Aly and Abuelnasr, 2010; Farahani et al., 2010; Ahmed et al., 2010; Kunanoppadon, 2010; Helmy and El-Taweel, 2010; Qutbodin, 2010; Pattanasethanon, 2010; Fen et al., 2011; Thongwan et al., 2011; Theansuwan and Triratanasirichai, 2011; Al Smadi, 2011; Tourab et al., 2011; Raptis et al., 2011; Momani et al., 2011; Ismail et al., 2011; Anizan et al., 2011; Tsolakis and Raptis, 2011; Abdullah et al., 2011; Kechiche et al., 2011; Ho et al., 2011; Rajbhandari et al., 2011; Aleksic and Lovric, 2011; Kaewnai and Wongwises, 2011; Idarwazeh, 2011; Ebrahim et al., 2012; Abdelkrim et al., 2012; Mohan et al., 2012; Abam et al., 2012; Hassan et al., 2012; Jalil and Sampe, 2013; Jaoude and El-Tawil, 2013; Ali and Shumaker, 2013; Zhao, 2013; El-Labban et al., 2013; Djalel et al., 2013; Nahas and Kozaitis, 2013; Petrescu and Petrescu, 2014a; 2014b; 2014c; 2014d; 2014e; 2014f; 2014g; 2014h; 2014i; 2015a; 2015b; 2015c; 2015d; 2015e; 2016a; 2016b; 2016c; 2016d; Fu et al., 2015; Al-Nasra et al., 2015; Amer et al., 2015; Sylvester et al., 2015b; Kumar et al., 2015; Gupta et al., 2015; Stavridou et al., 2015b; Casadei, 2015; Ge and $\mathrm{Xu}, 2015$; Moretti, 2015; Wang et al., 2015; Antonescu and Petrescu, 1985; 1989; Antonescu et al., 1985a; 1985b; 1986; 1987; 1988; 1994; 1997; 2000a; 2000b; 2001; Aversa et al., 2017a; 2017b; 2017c; 2017d; 2017e; 2016a; 2016b; 2016c; 2016d; 2016e; 2016f; 2016g; 2016h; 2016i; 2016j; 2016k; 2016l; 2016m; 2016n; 2016o; Cao et al., 2013; Dong et al., 2013; Comanescu, 2010; Franklin, 1930; He et al., 2013; Lee, 2013; Lin et al., 2013; Liu et al., 2013; Padula and Perdereau, 2013; Perumaal and Jawahar, 2013; Petrescu, 2011; 2015a; 2015b; Petrescu and Petrescu, 1995a; 1995b; 1997a; 1997b; 1997c; 2000a; 2000b; 2002a; 2002b; 2003; 2005a; 
$2005 \mathrm{~b} ; 2005 \mathrm{c} ; 2005 \mathrm{~d} ; 2005 \mathrm{e} ; 2011 \mathrm{a} ; 2011 \mathrm{~b} ; 2012 \mathrm{a}$; 2012b; 2013a; 2013b; 2013c; 2013d; 2013e; 2016a; 2016b; 2016c; Petrescu et al., 2009; 2016; 2017a; 2017b; 2017c; 2017d; 2017e; 2017f; 2017g; 2017h; 2017i; 2017j; $2017 \mathrm{k} ; 2017 \mathrm{l} ; 2017 \mathrm{~m} ; 2017 \mathrm{n} ; 2017 \mathrm{o} ; 2017 \mathrm{p} ; 2017 \mathrm{q}$; $2017 \mathrm{r} ; 2017 \mathrm{~s} ; 2017 \mathrm{t} ; 2017 \mathrm{u} ; 2017 \mathrm{v} ; 2017 \mathrm{w} ; 2017 \mathrm{x}$; 2017y; 2017z; 2017aa; 2017ab; 2017ac; 2017ad; 2017ae; 2018a; 2018b; 2018c; 2018d; 2018e; 2018f; 2018g; 2018h; 2018i; 2018j; 2018k; 20181; 2018m; 2018n).

\section{Materials and Methods}

A space probe is a space vehicle launched without human crew that aims to explore one or more celestial bodies - planet, moon, comet, the asteroid - or the interplanetary or interstellar medium. Its payload consists of scientific instruments of various kinds cameras operating or not in visible light, spectrometers, radiometers, magnetometers - which allow collecting data in situ or at a distance which are then transmitted to the Earth. If in its general architecture a space probe is often close to an artificial satellite orbiting the Earth, several characteristics make it special machines:

- The distance between the operators on the ground and the machine which imposes both a large autonomy and a communication system that is both powerful and precise

- The complexity of the tasks to be linked: Landing on celestial objects provided with an atmosphere or having very low gravity, the precise pointing of the instruments on high-speed moving targets, collection of samples, backup procedures in case of failure

- The accuracy and complexity of the navigation;

- Cosmic ray exposure

- The sophistication of scientific instrumentation related to the need to reduce payload and performance requirements

- The weakness of available solar energy if the probe is intended for the outer planets

- Much more extreme temperatures when the probe is sent to the outer planets or below the orbit of Mercury

- The duration of the mission which can begin after a transit of up to ten years

The missions of exploration of the solar system are expensive and therefore rare (some missions per year all space agencies combined) while the subjects of study are multiplying as and when the scientific advances. The selection process is therefore severe and highly regulated. The main space agencies rely to determine their space exploration strategy on documents produced by the main scientific authorities. For NASA is the Planetary Science Decadal Survey produced every ten years while the European Space Agency has had a similar document produced for its scientific program Cosmic Vision set up in 2004 for projects ending in 2015-2025. The French CNES, although having a research budget that does not allow it to carry out exploration of the solar system autonomously, proceeds in the same way. In this framework, a purely prospective call for ideas can be launched by the space agency followed by a call for proposals (AO). The latter normally leads to the selection and development of a mission. It is launched in a preestablished budget framework. At NASA, this budget line for a mission type is available periodically, as in the case of New Frontiers or Discovery, which allows developing respectively 2 and 4/5 missions per decade. ESA (which has only a fraction of NASA's budget) selects the missions very long before they are launched. The launch date is often postponed to cope with budget constraints. Teams that respond to tenders include engineers and scientists. They submit proposals detailing both scientific objectives, technical characteristics and financial aspects. The choice is made by scientific committees that take into account the long-term scientific strategy set by the documents produced by the academic authorities at the beginning of this process.

The exploration method used for a space probe is essentially determined by the scientific objectives pursued and the cost constraints. For example, if it is the first study of a planet, the idea is to place the space probe in orbit around it to make observations on the entire planet over long periods. But the setting in orbit requires adding a propulsion loaded braking which represents a major cost. For this reason, we can choose to perform a simple overview of the lens by optimizing the trajectory for scientific instruments to collect the maximum amount of data. Finally, the choice of a method of exploration is conditioned by the level of expertise of the nation or group of nations developing the space probe. The lowest level of difficulty is flying over an inner planet of the solar system. The removal of a partially autonomous rover on the planet Mars, characterized by a high gravity and an atmosphere, was only achieved in 2013 by NASA.

\section{Results and Discussion}

Depending on the exploration method used, space probes can be arranged in 9 main categories. Some space probes relate to several categories at once for example when they combine an orbiter and a landing gear (Viking, Fig. 1).

The Viking program consisted of a pair of American space probes sent to Mars, Viking 1 and Viking 2. Each ship was made up of two main parts: An orbiter designed to photograph the surface of Mars in orbit and ground to protect the planet on the surface. Orbits have also served as communication relays for those who have reached the threshold. 


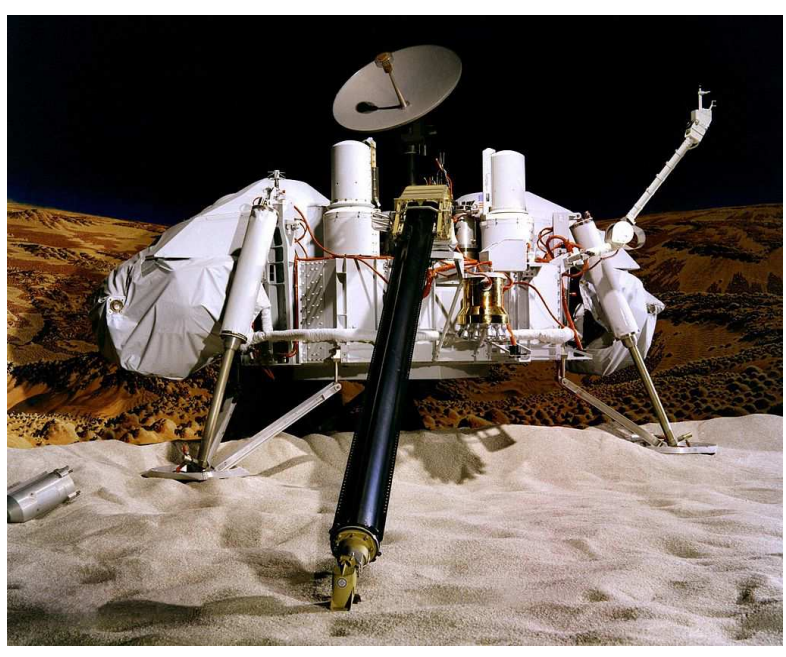

Fig. 1: Viking probe

The Viking program has grown from NASA's older, more ambitious program, Voyager Mars, which was not linked to Voyager's successful space probes in the late 1970s. Viking 1 was released on August 20, 1975 and Viking 1 was launched on September 9, 1975, both Titan IIIE missiles with superior Centaur instruments. Viking 1 entered Mars orbit on June 19, 1976, with Viking 2 following on August 7.

After they marched Mars for more than a month and turned the images used to select the landing places, the shutters and detachments were detached; the descent then entered into the Martian atmosphere and landed gently in the places that had been chosen. Viking 1 arrived on Mars on July 20, 1976 and joined Viking Landing on September 2. 3. Orbit continued to photograph and perform other orbital scientific operations, while the vessels used surface instruments.

The project cost about $\$ 1$ billion in US dollars in 1970 , equivalent to about $\$ 5$ billion in $\$ 2018$. The mission was considered successful and is credited to help build the most knowledge about Mars by the late 1990s and early 2000 s.

The primary objectives of the two Vikings were to transport Mars hooks, to recognize the location and certification of landing sites, to act as landing communications relays and to conduct their own scientific research. Each dazzling, based on Mariner 9, was an octagon of about $2.5 \mathrm{~m}$. The dazzling pocket, with a complete fire, had a mass of $3527 \mathrm{~kg}$. After separation and landing, the soil had a mass of about 600 $\mathrm{kg}$ and an orbit of $900 \mathrm{~kg}$. The total weight of the launch was $2328 \mathrm{~kg}$, of which $1445 \mathrm{~kg}$ was the attitude of fuel and gas control. The eight sides of the ring structure have a height of $0.4572 \mathrm{~m}$ and have alternate widths of 1.397 and $0.508 \mathrm{~m}$. The overall height was $3.29 \mathrm{~m}$ from the ground clamping points to the bottom of the vehicle's grip points launched at the top. There were 16 modular compartments, 3 on each of the four long faces and one on each short face. Four wings of solar panels were extended from the axis of the orbit, the distance from the top to the top of two extended solar panels was $9.75 \mathrm{~m}$.

The main propulsion unit was mounted above the orbital bus. The propulsion was provided by a rocket engine with bipropellant (monomethyl hydrazine and nitrogen tetroxide), which could be trained up to 9 degrees. The engine was capable of a displacement of $1,323 \mathrm{~N}$ (297 lbf), offering a speed change of $1480 \mathrm{~m} / \mathrm{s}$. Attitude control was achieved by 12 small jets of compressed nitrogen.

An acquisition sun sensor, a cruise flight sensor, a Star Canopus tracker and an inertial reference unit, composed of six gyroscopes, allowed three-axis stabilization. There were two accelerometers on board. Communications were conducted via $20 \mathrm{WS}(2.3 \mathrm{GHz})$ transmitters and two 20W TWTA transmitters. An X band $(8.4 \mathrm{GHz})$ was also added specifically to radio communications and experiments. Uplink was through the S-band (2.1 GHz). A two-axis parabolic antenna with a diameter of approximately $1.5 \mathrm{~m}$ was attached to an edge of the orbital base and a fixed low gain antenna was extended from the top of the bus. Two tape recorders were able to store 1280 megabytes. A $381 \mathrm{MHz}$ relay radio was also available.

The power of the two orbital boats was assured by eight solar panels of $1.57 \times 1.23 \mathrm{~m}$, two on each wing. Solar panels have a total of 34,800 solar cells and produced 620 powers on Mars. Power was also stored in two nickel-cadmium batteries $30-\mathrm{A} \cdot \mathrm{h}$.

The combined area of the four panels was 15 square meters (160 square meters) and provided both regular and irregular power; unregulated power was provided to the radio transmitter and take-off device.

Two 30-hour nickel-cadmium rechargeable batteries provided energy when the spacecraft was not facing the sun and Mars's correction and obfuscation maneuvers.

Discovering many geological forms commonly formed of large amounts of water, the images of the blind have revolutionized our ideas about Mars water. Large river dwellings have been found in many areas. They have shown that water floods have broken dams, deeply carved valleys, eroded canals and thousands of kilometers. The large hemisphere in the southern hemisphere contains branched-flow networks, suggesting that the rain fell once. It is believed that the flanks of some volcanoes have been exposed to precipitation because it resembles those produced on Hawaiian volcanoes. Many craters show that the impact element has fallen into the mud. When they were formed, the ice in the soil would melt, turn the earth into the mud and then cross the surface. Normally, the material from an impact increases, then down. It does not flow over the surface, going around the obstacles, as is 
the case with martial craters. The regions, termed chaotic Terrain, seemed to have quickly lost large volumes of water, causing large channels to form. The amount of water involved was estimated at ten thousand times larger than the Mississippi River. Underground volcanism can be melted by ice; the water then leaked and the earth collapsed to leave the chaotic terrain.

Each platform consisted of a six-sided aluminum base with long sides of 1.09 and $0.56 \mathrm{~m}(3 \mathrm{ft} 7 \mathrm{in}$ and $1 \mathrm{ft}$ 10 in) supported on three extended legs attached to the shorter sides. The legs of the legs formed the vertices of an equilateral triangle with the sides of $2.21 \mathrm{~m}$, seen from above, the long sides of the base being formed by a straight line with the two adjacent legs. The instrumentation was attached to the inside and above the base, raised above the surface by the extended legs.

Each landing device was closed in a thermal ventilation screen designed to slow the discharge during the intake phase. To prevent contamination with Mars by the Earth's organisms, each landing was closed in a "bioshield" under pressure and then sterilized at a temperature of $111^{\circ} \mathrm{C}\left(40^{\circ} \mathrm{F}\right)$ for 40 hours. For thermal reasons, the cover of the bio-shield was removed after the Centaur upper phase powered the Viking orbiter/lander combination into the Earth's orbit.

Each landing arrived on Mars attached to the orbit. The ensemble has blinded itself to Mars several times before the soil is released and detached from orbit to descend to the surface. The descent contained four distinct phases, starting with burning. The creditor then experienced top-of-the-air warming, which took place a few seconds after the start of friction heating with the Martian atmosphere. At an altitude of about $6 \mathrm{~km}$ and traveling at a speed of $900 \mathrm{~km} / \mathrm{h}(600 \mathrm{mph})$, the parachute was launched, the aerosol was released and the hips weakened. At an altitude of about 1.5 kilometers, the lander activated his three retro-engines and was released from the parachute. The lender immediately used the buttons to slow down and control the descent, with a soft landing on Mars' surface.

Propulsion was provided by mono propel hydrazine (N2H4) through a 12-ship rocket disposed of in four groups of three, providing a force of 32 newtons (7.2 $\mathrm{lbf}$ ), translating a change of $180 \mathrm{~m}$ (590) and rotation of the landing gear.

Lowering the terminals (after using a parachute) and landing allowed the use of three single-propelled hydraulic motors (one mounted on each side of the base, separated by 120 degrees). The engines had 18 nozzles to disperse the exhaust gases and to minimize the effects on the soil and were sparkling from 276 to 2667 newtons (62 to $600 \mathrm{lbf}$ ). Hydrazine was purified to prevent contamination of Martian surface with microbes in the earth. Lander transported $85 \mathrm{~kg}$ of fuel containing two titanium glass tanks mounted on the opposite sides of the soil under the X-ray windshield, giving a total launch weight of $657 \mathrm{~kg}$ (1448 lb). The control was performed using an inertial reference unit, four gyroscopes, a radar altimeter, one terminal take-off radar and a landing, as well as a commander's propulsion.

Power was provided by two radio-isotopic units of thermoelectric generators (RTGs) containing 239 plutonium fixed to the opposite sides of the ground and covered with windscreens. Each generator had a height of $28 \mathrm{~cm}$ (11 inches), $58 \mathrm{~cm}$ (23 in) in diameter, had a mass of $13.6 \mathrm{~kg}(30 \mathrm{lb})$ and provided a continuous power of $30 \mathrm{~W}$ at $4.4 \mathrm{~V}$ Four layers of 28,800 nickelnickel coulombs, 28 volt rechargeable batteries were loaded to charge peak loads.

The communications were conducted through a $20 \mathrm{~W}$ transmitter S using two displacement wave tubes. A twoaxis parabolic antenna with high maneuverability was mounted on an arm near the landing edge. An omnidirectional low gain antenna extends from the base. Both antennas allow direct communication with the Earth, allowing Viking 1 to continue working long after both failures. The UHF antenna (381 MHz) provided a single relay using a 30 -watt relay radio. Data storage was on a 40 Mbit tape recorder and the creditor's computer had a memory of 6,000 words for command instructions.

The instructor used tools to achieve the primary science objectives of the lander mission: The study of biology, chemical composition (organic and inorganic), meteorology, seismology, magnetic properties, appearance and physical properties of the Martian surface and atmosphere. Two 360-degree cylindrical scanning cameras were mounted near alongside the base. From the center of this section extends the sampling arm, with a collector head, temperature sensor and magnet at the end. A meteorological arm, retention temperature, wind direction and wind speed sensors have expanded and expanded from the top of one of the grip legs. A seismometer lens, magnet and test chamber and magnifying mirror are mounted in front of the cameras, near the high gain antenna. A compartment controlled with the inner environment held the biological experiment and mass spectrometer with a gas chromatograph. The Xray fluorescence spectrometer was also mounted in the structure. A pressure sensor was attached under the body. The scientifically useful volume had a total weight of approximately $91 \mathrm{~kg}(201 \mathrm{lb})$.

Viking Plot has conducted biological experiments designed to detect the life of Martian soil (if any) with experiments designed by three separate teams led by NASA chief scientist Gerald Soffen. One experiment was positive for the detection of metabolism (current life), but based on the results of the two other experiments that failed to reveal any organic molecule in the soil, most scientists were convinced that positive results are probably due to strong soil oxidation. 
Although there is a consensus that Viking results have shown a lack of ground biosignals at the two landing sites, test results and boundaries are still under evaluation. The validity of LR is based entirely on the absence of an oxidizing agent in Martian soil but was subsequently discovered by Phoenix soil as perchlorate salts. It was proposed that organic compounds be present in the soil analyzed by both Viking 1 and Viking 2 but remained unnoticed due to the presence of perchlorate detected by Phoenix in 2008. Researchers found that perchlorate would destroy organic substances when heated and produce chloromethane and dichloromethane, the same chlorine compounds discovered by both Viking flights when performing the same tests on Mars.

The issue of microbial life on Mars remains unresolved. However, on April 12, 2012, an international team of scientists reported studies based on mathematical speculation, analyzing the complexity of experiments launched on Labeled in the 1976 Viking Mission, which may suggest detecting "existing microbial existence on Mars.

The leader of the imaging team was Thomas Mutch, a geologist at Brown University in Providence, Rhode Island. The camera uses a mobile mirror to illuminate 12 photodiodes. Each of the 12 silicon diodes is designed to be sensitive to different frequencies of light. Several diodes are positioned to accurately focus at distances between 6 and $43 \mathrm{~m}$ away from the ground.

Scanned devices have a scan rate per second, each with 512 pixels. The 300-degree panoramic images were composed of 9,150 lines. Scanning the cameras was slow enough that, in a team, more members.

Spatial probes can be designed to perform a simple overview of the celestial object to be studied. In the simplest cases, these probes must only be placed on a precise trajectory from the Earth to carry out their missions at the cost of a few small corrections during transit. The first interplanetary probes like Mariner 4 (Fig. 2) were of this type.

Mariner 4 (along with Mariner 3, known as MarinerMars 1964) was the fourth in a series of spacecraft designed for planetary exploration in a flyby way. It was designed to make close scientific observations of Mars and transmit these observations to Earth. Launched on November 28, 1964, Mariner 4 made Marte's first successful navigation plan, transforming the first background images of the Martian surface. He captured the first images of another planet ever turned from deep space; their description of a dark and seemingly dead world has greatly changed the vision of the scientific community about life on Mars. Other objectives of the mission were space and space measurements and the provision of experience and knowledge about engineering capabilities for long-term interplanetary flights. On December 21, 1967, communications with Mariner 4 ceased.

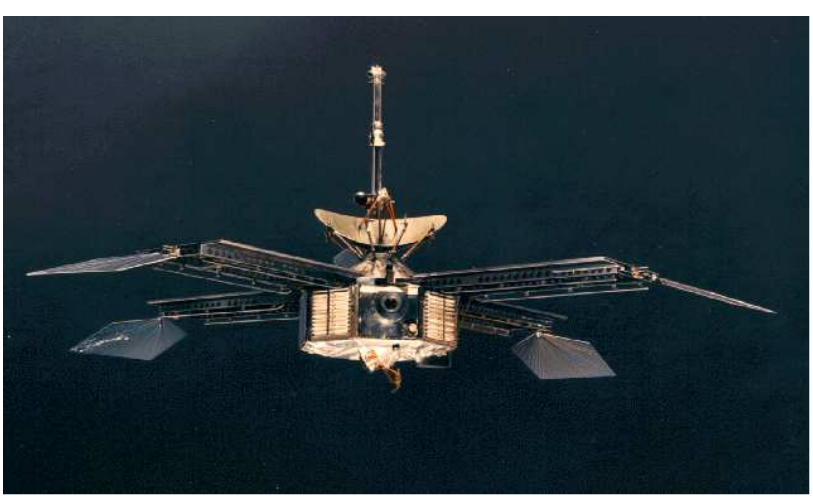

Fig. 2: Spacecraft Mariner 4

Spacecraft Mariner 4 consisted of an octagonal frame with a diagonal of $127 \mathrm{~cm}$ and a height of $45.7 \mathrm{~cm}$. Four solar panels were attached to the top of the frame, having an end of $6.88 \mathrm{~m}$, including solar pressure slides extending from the ends. A parabolic antenna of the high height of $116.8 \mathrm{~cm}$ was mounted at the top of the frame. The omnidirectional low gain antenna was mounted at a height of 7 inches, $223.5 \mathrm{~cm}$ high, near the high gain antenna. The total height of the spacecraft was 2.89 meters. The octagonal frame was equipped with electronic equipment, harnesses, timely propulsion and gas supply and attitude controllers.

\section{Scientific Instruments Included}

A helium magnetometer mounted on the waveguide that drives the omnidirectional antenna to measure the magnitude and other features of the interplanetary and planetary magnetic fields.

A Geiger ion/ion counter mounted on the waveguide that drives the omnidirectional antenna closer to the spacecraft's body to measure the intensity and distribution of charged particles in the interplanetary space and Mars.

A captured radiation detector, mounted on the body with counter-axes oriented at $70^{\circ}$ and $135^{\circ}$ in the direction of the sun, to measure the intensity and direction of the low-energy particles.

A cosmic ray telescope, mounted inside the body, indicating an anti-solar direction to measure the direction and energy spectrum of protons and alpha particles.

A solar plasma probe mounted on the body at 10 degrees to the sun to measure the flow of charged particles of very low solar energy.

A cosmic dust detector, mounted on the body with a microphone plate approximately perpendicular to the plane of the orbit, to measure the impulse, distribution, density and direction of the cosmic dust.

A television camera, mounted on a scanning platform in the center of the ship's center, to get close-up images of Mars. This subsystem comprises 4 parts, a Cassegrain 
telescope with a viewing range of $1.05^{\circ}$ to $1.05^{\circ}$, a shutter and a set of red/green filters with an exposure duration of $0.08 \mathrm{~s}$ and $0.20 \mathrm{~s}$, a vidicon scan tube that translates the video signal and the electronic systems needed to convert the analog signal into a digital bitstream for transmission.

The power tool and the Mariner 4 radio transmitter were delivered by 28,224 solar cells contained in the four $176 \times 90 \mathrm{~cm}$ solar panels that could provide a 310 watt edge. A rechargeable $1200 \mathrm{~W} \cdot \mathrm{h}$ silver-zinc battery was used and for maneuvers and reserve. Hydraulic propulsion was used for propulsion through a four-jet vector control engine with a pressure of 222 newtons (50 lbf) installed on one of the sides of the octagonal structure. The control of the probe space attitude was assured by 12 cold nitrogen gas jets mounted at the ends of the solar panels and three gyroscopes. The solar pressure panels, each with a surface of seven $\mathrm{ft}^{2}$, were attached to the top of the solar panels. Position information was provided by four sun sensors and a Terra, Marte or Canopus Star sensor, depending on the time spent in its space. Mariner 4 was the first spacecraft to need a star for a navigation reference, as Earth, Moon or Venus earlier missions saw either the brilliant face of the planet of origin, the burning target. During this flight, both the Earth and Mars would be too weak to block. Another source of light at a wide angle from the Sun was necessary and Canopus fulfilled this heaven.

Mariner's telecommunication devices consist of Sband transmitters (a seven-watt three-dimensional cavity amplifier or a 10 -watt protective amplifier) and a single radio receiver that together can send and receive 8-bit or 33-bit data per second. The data could also be stored on a 5.24-million-bit tape recorder for subsequent transmission. All electronic operations were controlled by a command subsystem that could process any of the 29 direct command words or three command words for maneuvers midway. The central computer and sequence command the stored timestamps using a $38.4 \mathrm{kHz}$ synchronization frequency as a reference. Temperature control was achieved by using adjustable slots mounted on six electronic assemblies, plus multilayer insulating sheets, polished aluminum shields and surface treatments. Other measurements that can be performed include:

- Radio has appeared

- Heavenly technology based on precision tracking

After Mariner 3 was a total loss due to the failure of the payload, JPL engineers suggested that there was a failure caused by the outer separation of the metal plates from the glass fiber inner liner due to the pressure differences between the inner and outer part of the shroud and that this could have caused the arc separation mechanism to get tangled and not detached properly.
Testing at JPL has confirmed this failure and efforts have been made to develop a new metal edition. The downside was that the new platform would be significantly larger and reduce the capacity of the AtlasAgena lift. Convair and Lockheed-Martin were supposed to do more performance improvements to get more power out of it. Despite fears that the work could not be completed before the window of March 1964 was closed, the new shroud was ready by November.

After launching the Cape Canaveral 12 launch complex, Mariner 4 was removed and the AgenaD/Mariner 4 combination was separated from the AtlasD rocket at 14:27:23 UTC on November 28, 1964. The first firing of the Agena had place in 14: 28: 14 and $14: 30: 38$. The initial launch put the spacecraft in a ground parking orbit and the second burning at 15:02:53 at 15:04:28 injected the craft into a transfer orbit on Mars. Mariner 4 broke away from Agena at 15:07:09 and began to travel. The solar panels installed and the scanning platform was disconnected at 15:15:00. The accumulation of the sun occurred after 16 minutes.

After Sun's acquisition, the Star Canopus tracker searched for Canopus. The Star Tracking System has been set to respond to any object more than one eighth and less than eight times lighter than Canopus. Including Canopus, there were seven such objects visible to the sensor. It took more than a day of "hip-hop" to find Canopus because the sensor was blocked by other stars: in front of Canopus an exterior model, Alderamin, Regulus, Naos and Gamma Velorum.

A consistent problem that affected the spacecraft during the first part of its mission was that the transitions of the roll error signal would occur frequently and would occasionally cause the loss of the Canopus star block. The first half-race attempt was canceled by a loss of lock shortly after the gyroscopes began to spin. Canopus's blocking has been lost six times in less than three weeks of launch and each time a series of radio commands are needed to recover the star. After a study of the problem, the investigators concluded that the behavior was due to the small particles of dust that were released by spacecraft by some means and traveling through the field of vision of the sensor. The light of the sun scattered from the particles appears as an illumination equivalent to that of a bright star. This would result in a transient rolling error because the object passed through the field of view while the sensor was blocked on Canopus. When the object was brilliant enough to exceed the gate limit of eight times the Canopus intensity, the ship will automatically initiate a search for a new star. Finally, a radio command was sent on December 17, 1964, which eliminated the upper limit of the gate. There was no further loss of Canopus lock, although there were 38 passes before meeting with Mars.

Mission return dates were 5.2 million bits (approximately $634 \mathrm{~KB}$ ). All instruments worked 
successfully, with the exception of one part of the ionization chamber, namely the Geiger-Müller tube, which failed in February 1965. In addition, the plasma probe had the degraded performance of a defect of resistance on December 8, 1964, but experimenters have been able to recalibrate the instrument and continue to interpret the data. Returned images showed a land similar to the Moon, which scientists did not expect, although amateur astronomer Donald Cyr predicted craters. Later, missions showed that craters were not typical of Mars, but only for the older region recorded by Mariner 4, a pressure of 4.1-7.0 millibars (410-700 Pascal) and a temperature of -100 degrees Celsius. There are no magnetic fields or Martian radiation belts or, surprisingly, the surface water was again detected at that time.

The objectives that can be achieved by this type of mission are however limited: The observation time is very short because the probe is flying over a speed of several $\mathrm{km} / \mathrm{s}$, often only one side of the celestial body is visible at the time of over-flight and lighting conditions are not optimal. This method of observation may be the only one that can be used for the most distant celestial objects (see Pluto by New Horizons, Fig. 3).

New Horizons is an interplanetary space probe launched as part of NASA's New Frontiers program. Designed by Johns Hopkins University, the Applied Physics Laboratory (APL) and the South West Research Institute (SwRI), with a team led by S. Alan Stern, the ship was launched in 2006 with the primary mission of conducting a study of Pluto 2015 and a secondary mission to fly and study one or more Kuiper belt items in the next, including MU69 2014 in 2019. It is the fifth space probe to achieve the evacuation speed required to leave the system solar.

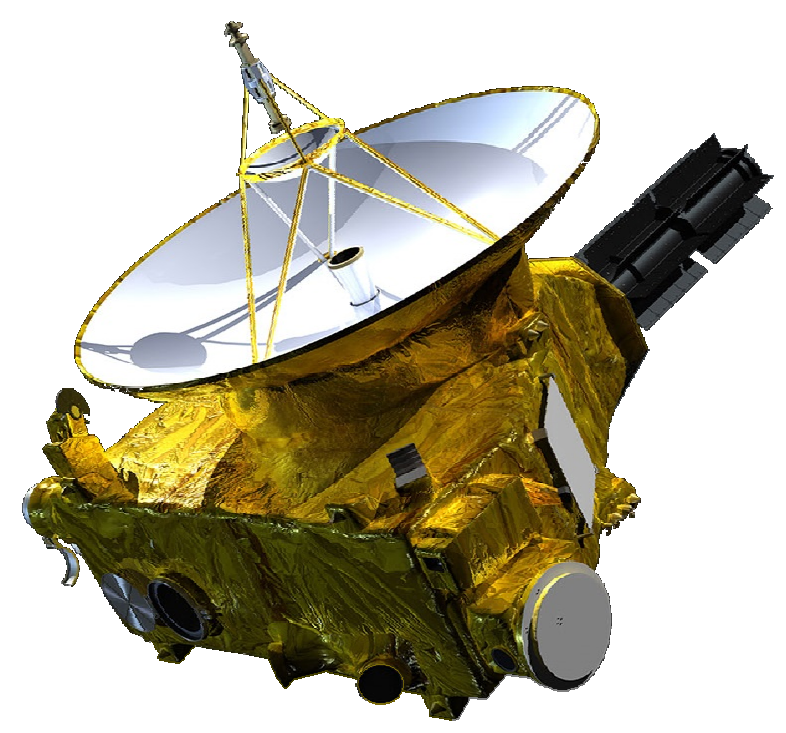

Fig. 3: New horizons
On January 19, 2006, New Horizons was launched from Cape Canaveral Air Station by an Atlas V rocket directly on a trajectory of the earth and the sun at a speed of $10.10 \mathrm{mi} / \mathrm{s}$ and $58,500 \mathrm{~km} / \mathrm{h} ; 36,400 \mathrm{mph}$ ). This was the fastest anthropic object ever produced on Earth. After a brief encounter with the asteroid 132524 APL, New Horizons proceeded to Jupiter, approaching the nearest approach on February 28, 2007, at a distance of 2.3 million kilometers. Jupiter flyby has provided gravity assistance that has increased New Horizons speed; has also allowed a general test of the scientific capabilities of New Horizons, which returns data about the planet's atmosphere, the moon and the magnetosphere.

Most of the post-Jupiter trip was spent in hibernation mode to keep the systems on board, except for short annual leaks. On December 6, 2014, new horizons were brought online for Pluto's meeting and began checking. On 15 January 2015, the spacecraft began its approach with Pluto.

On 14 July 2015, at 11:49 UTC, he flew $12,500 \mathrm{~km}$ $(7,800 \mathrm{mi})$ above Pluto, becoming the first spacecraft to explore the dwarf planet. On October 25, 2016, 21:48 UTC, Pluto's latest data was received from New Horizons. After completing his trip to Pluto, New Horizons maneuvered 201420142014 "The Last Thule" (486958) 2014, which took place on January 1, 2019, when it was 43.4 AU from the Sun. In August 2018, NASA quoted Alice's results on New Horizons to confirm the existence of a "hydrogen wall" at the outer edges of the Solar System. This "wall" was first detected in 1992 by the two spacecraft Voyager.

In August 1992, JPL scientist Robert Staehle named Pluto discoverer Clyde Tombaugh asking for permission to visit the planet. "I told him he was welcome," Tombaugh later remembered, "though he has to go on a long and cold journey." The appeal eventually led to a series of proposed Pluto missions that led to New Horizons.

Stomatios "Tom" Krimigis, head of the Division of Applied Physics Laboratories, one of the most participants in the New Frontiers program, formed the New Horizons team with Alan Stern in December 2000. As the main investigator of the project, Stern was described by Krimigis as "personification of the Pluto mission". New Horizons relies heavily on Stern Pluto 350 's work and involves most of the team at Pluto Kuiper Express. The proposal for the new horizons was one of the five, which was officially presented to NASA. Later, he was selected as one of the two finalists to undergo a three-month conception study in June 2001. The other finalist, Pluto and Outdoor Solar System Explorer (POSSE), was a separate concept in Colorado Boulder, led by lead researcher Larry W. Esposito, supported by JPL, Lockheed Martin and the University of California. However, APL, in addition to being 
supported by Pluto Kuiper Express developers at Goddard Space Flight Center and Stanford University, was a good one; have recently developed NEAR Shoemaker for NASA, which successfully entered orbit around 433 Eros earlier this year and later landed on the asteroid for science and fanfare engineering.

In November 2001, New Horizons was officially selected for funding as part of the New Frontiers program. However, NASA's new administrator, appointed by the Bush Administration, Sean O'Keefe, did not support the New Horizons and in fact, canceled it by not including it in NASA's 2003 budget. NASA, Ed Weiler Sciences, led Stern to lobby for New Horizons, hoping the mission would appear in the Decadal Study of Planetary Sciences; a priority list of wishes, developed by the United States National Research Council, which reflects the views of the scientific community.

New Horizons is the first mission of the New Frontiers mission, larger and more expensive than Discovery missions, but less than the Flagship program. The cost of the mission (including spacecraft and instrument development, vehicle launch, mission operations, data analysis and education/public information) is approximately $\$ 700$ million over 15 years (2001-2016). Spacecraft was built primarily by the Southwest Research Institute (SwRI) and Johns Hopkins Applied Physics Laboratory. The Head of Mission is Alan Stern of the South West Research Institute (former NASA Associate Administrator).

After separation from the launch vehicle, general control was performed by the Mission Operations Center (MOC) at the Applied Physics Laboratory in Howard County, Maryland. The scientific instruments are operated at the Clyde Tombaugh Science Center (TSOC) in Boulder, Colorado. Navigation takes place in different contractor facilities, while navigational position data and Celestian reference frames are provided by the Flagstaff Observatory via NASA and JPL headquarters; KinetX is the leader of the New Horizons navigation team and has the task of planning route trajectories as the speed of the spacecraft extends to the outer solar system. Coincidentally, Flagstaff's ship observation station was the one where photographic plates were taken to find the moon of Pluto Charon and the Naval Observatory is not far from Lowell Observatory, where Pluto was discovered.

New horizons were originally planned as a trip to the only unexplored planet in the Solar System. At the launch of the spacecraft, Pluto was still classified as a planet reclassified by the International Astronomers Union (IAU) as a dwarf planet. Some New Horizons team members, including Alan Stern, disagree with the IAU definition and still describe Pluto as the new planet. The Pluto Nix and Hydra satellites also have a connection with the spacecraft: The first letters of their names ( $\mathrm{N}$ and $\mathrm{H})$ are the initials of New Horizons. Monthly discoverers chose these names for this reason, plus Nix and Hydra's relationship with the mythological platoon.

In addition to scientific equipment, there are several cultural artifacts that travel with the spacecraft. These include a collection of 434,738 names stored on a compact disc, a SpaceShipOne piece from Scaled Composites, a USPS "Not yet explored" and a US flag along with other reminders.

About 30 grams of ash by Clyde Tombaugh is on board the commemoration of Pluto's discovery in 1930. A Florida State Coin whose design commemorates human exploration is officially included as a final weight. One of the scientific packs (a dust counter) is named after Venice Burney, who, as a child, suggested the name "Pluto" after his discovery.

The aim of the mission is to understand the formation of the plutonic system, the Kuiper belt and the transformation of the early solar system. Spacecraft collected data on Pluto's atmosphere, surfaces, interiors and environments, as well as about its moons. He will also study other Kuiper belt objects. "By comparison, New Horizons gathered 5000 times more data about Pluto that Mariner made at Red Planet."

Some of the questions the mission is trying to answer are: What is Pluto's atmosphere and how does it behave? How does his surface look like? Are there large geological structures? How does solar wind particles interact with Pluto's atmosphere?

Specifically, mission science objectives are:

- The composition of Pluto and Charon's maps

- Characterizes the geology and morphology of Pluto and Charon, characterize Pluto's neutral atmosphere and escape rate, look for an atmosphere around Charon, map of surface temperatures on Pluto and Charon, look for rings and additional satellites around Pluto, conducts similar investigations of one or more Kuiper belt objects

The space ship is comparable in size and shape to a large piano and was compared to a piano locked in a cocktail bar antenna. As a starting point, his team was inspired by the space ship Ulysses, which also carried a Radio-isotope Thermoelectric (RTG) and a ship on a box-in-box structure through the external solar system. Many subsystems and components have FLO mosaic in the CONTOUR space vessel, which in turn has the patrimony of the spacecraft APL TIMED.

The New Horizons body forms a triangle with a thickness of nearly $0.76 \mathrm{~m}(2.5 \mathrm{ft})$. (The pioneers have hexagonal bodies, while Voyagers, Galileo and CassiniHuygens have decorative and bare bodies.) An alloy tube 7075 forms the main structural column between the "6" 
11 step radio antenna, the titanium offers resistance and thermal insulation, the rest of the triangle being mainly aluminum sandwich panels (under $1 / 64$ or $0.40 \mathrm{~mm}$ ) glued into an aluminum honeycomb structure larger than the strictly necessary interior space. The structure is designed to act as shielding, reducing electronic errors caused by X-rays. Also, the mass distribution required for a spacecraft requires a wider triangle.

The interior structure is painted in black to equalize the temperature by radiant heat transfer. In general, spacecraft are crowded to keep the heat. Unlike pioneers and travelers, the radio mine is also enclosed in blankets that extend to the body. The heat from the RTG adds heat to the ship as it is in the outer solar system. While in the internal solar system, spacecraft must prevent overheating, electronic activity is limited, power is diverted to travel with attached radiators and shutters are open to radiate excess heat. While spacecraft move inactive in cold outside the solar system, the shutters are closed and the shunt regulator redirects energy to electric heaters.

The new horizons have both stabilization modes (cruise) and three stabilized (scientific) axes, fully controlled by monopropyl hydrazine. Due to an internal $77 \mathrm{~kg}(170 \mathrm{lb})$ tank, an extra plus of $290 \mathrm{~m} / \mathrm{s}(1000 \mathrm{~km} / \mathrm{h}, 650 \mathrm{mph})$ is provided. The helium is used as a gasifier with an elastomeric membrane that helps expel. Spacecraft circulating in orbit, including fuel, are over $470 \mathrm{~kg}(1,040 \mathrm{lb})$ on Jupiter, but it would have been just $445 \mathrm{~kg}(981 \mathrm{lb})$ for the direct reserve option to Pluto. Significantly, if the backup option was taken, this would have meant less fuel for subsequent Kuiper band operations.

There are 16 holes on the new horizons: Four $4.4 \mathrm{~N}$ (1.0 lbf) and twelve $0.9 \mathrm{~N}$ (0.2 lbf) plumbed in redundant branches. The larger ones are mainly used to correct the paths and the smallest ones (previously used for Cassini and Voyager) are mainly used for spin-spindown maneuvers and spindown maneuvers. Two-star rooms are used to measure the attitude of the spacecraft. They are mounted on the ship's side and provide information in 3 or 3 directions. Between starboard reading, the orientation of the spacecraft is provided by redundant inertial measurement units in miniature. Each unit contains three solid gyroscopes and three accelerometers. Two Adcole Sun sensors ensure the determination of attitude. The angle is detected in the Sun, while the other measures measure clock rotation and speed.

A radial radial radial radiator (X-ray radiator) extends into a triangular plane on a triangle tip. RTG delivered 245.7 watts at launch and was estimated to fall by about 3.5 watts each year to 202 watts when it meets the plutonic system in 2015 and will drop too much to power the transmitters in 2030 There are no batteries at board as an X-ray output is predictable and transient loads are treated through a series of capacitors and short circuit breakers. Starting in January 2019, the output power of the RTG is about $190 \mathrm{~W}$.
RTG, the "GPHS-RTG" model, was originally a reserve from the Cassini mission. RTG contains $9.75 \mathrm{~kg}$ $(21.5 \mathrm{lb})$ of plutonium oxide-238 pellets. Each pellet is dressed in iridium, then wrapped in a graphite shell. It was developed by the US Department of Energy. of the Materials and Fuels Complex, part of the Idaho National Laboratory. The original RTG project required 10.9 kilograms of plutonium, but a unit less powerful than the original target was due to delays from the US Department of Energy, including security activities that delayed plutonium production. Mission parameters and observation sequence had to be modified for reduced power; however, not all instruments.

The amount of radioactive plutonium in RTG represents about one-third of the amount of CassiniHuygens on board when it was launched in 1997. This launch was protested by some of them. The US Department of Energy has estimated the chance of a launch accident that would release atmospheric radiation to 1 in 350 and will monitor the launch, as is always the case with the involvement of RTGs. It was estimated that the worst-case scenario of on-board plutonium dispersion would produce radiation equivalent to $80 \%$ of the average annual radiation dose in North America over a $105 \mathrm{~km}(65 \mathrm{~m})$ radius.

The spacecraft transports two computer systems: The data control and manipulation system and the control and control processor. Each of the two systems is doubled for redundancy, for a total of four computers. The processor used for its flight computers is Mongoose- $\mathrm{V}$, a $12 \mathrm{MHz}$ version with MIPS R3000 processorresistant radiation. Multiple redundant clocks and synchronization routines are implemented in hardware and software to prevent malfunctions and downtime. For storage of heat and mass, spacecraft and electronic tools are housed together in integrated electronic modules (IEMs). There are two redundant IEMs. Including other functions, such as instrument electronics and radio, each IEM contains 9 panels. The probe software runs on the Nucleus RTOS operating system.

\section{There Were Two "Safe" Events that Sent the Ship Safely}

On March 19, 2007, the data manipulation and data processing computer encountered a memory error that could not be recovered and resumed, causing the spacecraft to enter secure mode. The boat was completely recovered in two days, with a loss of data about Jupiter's magneto. No impact on the subsequent mission was expected.

On July 4, 2015, a secure CPU event occurred due to over-allocation of scientific operations commissioned on Pluto craft. Fortunately, craft managed to recover in two days without having a major impact on its mission.

Communication with the spacecraft is done via $\mathrm{X}$ band. Boats had a communication rate of $38 \mathrm{kbit} / \mathrm{s}$ for 
Jupiter; at Pluto's distance, a transmission of about 1 $\mathrm{kbit} / \mathrm{s}$ was expected. In addition to the low data rate, Pluto's distance determines a latency of about 4.5 hours (in a certain sense). 70-foot NASA Deep Space (DSN) network levels are used to control the relays once they are outside Jupiter. Spacecraft use modular transmitters and modular receivers and circular polarization to the right or left. The downlink signal is amplified by two small $12 \mathrm{~W}$ (TWTA) gabion amplifiers mounted on the antenna body. Receivers are new models with low power. The system can be controlled to simultaneously power both TWTAs and transmit a downward polarized signal to the DSN that nearly doubles the downlink rate. DSN tests at the beginning of the mission with this dual polarization combining technique have been successful and capability is now considered operational (when the ship's power budget allows the use of both TWTAs).

In addition to the high gain antenna, there are two low gain rescue antennas and a medium gain vessel. High-quality food has a Cassegrain reflective design, a composite structure of $2.1 \mathrm{~m}(7 \mathrm{ft})$, which provides a gain of over $42 \mathrm{dBi}$ and a power beam width of about a certain degree. The average gain antenna with a $0.3-$ meter diaphragm and a 10-degree beam width is mounted on the rear side of the high-beam antenna's secondary reflector. The low gain antenna is stacked above the average gain antenna. The small gain hook antenna is mounted in the launch adapter behind the spacecraft. This antenna was used only for Earth's early missions, immediately after launch and for emergencies, if the spacecraft lost control of the attitude.

The new horizons recorded the data of the scientific instrument to the solid memory buffer at each meeting, then transmitted the data to Terra. The data is stored on two low-power semiconductors (one primary, one available) with a capacity of up to 8 gigabytes each. Due to the extreme distance from Pluto and the Kuiper belt, only a buffer load can be saved in those meetings. This is due to the fact that the new horizons will take about 16 months after they left the Pluto approach to transmitting the buffer load.

Part of the reason for the delay between data collection and transmission is that all New Horizons are mounted on the body. For the cameras to record data, the entire probe must return and the high-velocity beam of the high gain antenna does not go to Earth. Previous antennas, such as the Voyager probes, had a rotating tool platform (a "scanning platform") that could measure almost any angle without losing the radio contact with the Earth. The new horizons have been mechanically simplified to save weight, shorten the schedule and improve reliability during its 15 -year life.

The Voyager 2 scanning platform was blocked at Saturn and the long-term exposure requirements on the outer planets led to a change of plan so that the entire probe was rotated to take Uranus and Neptune, similar to how the horizons rotate.

The new horizons have seven instruments: Three optical instruments, two plasma instruments, a dust sensor and a radio/radiometer receiver. The instruments will be used to investigate global geology, surface composition, surface temperature, atmospheric pressure, atmospheric temperature and discharge rate of Pluto and its moons. The nominal power is 21 watts, although not all instruments work simultaneously. In addition, New Horizons has an Ultrastable Oscillator subsystem that can be used to study and test the Pioneer anomaly towards the end of spacecraft life.

The Remote Recognition Detector (LORRI) is a focal point for wavelengths with high and sensitive resolution. The instrument is equipped with a pixel of $1024 \times 1024$ pixels, with a 12-bit per pixel monochrome CCD that offers a resolution of $5 \mu \mathrm{rad}(\sim 1 \mathrm{arc})$. The CCD is frozen by a passive radiator on the ship's antisolar space. This temperature difference requires isolation and isolation from the rest of the structure. Ritchey-Chretien The $208.3 \mathrm{~mm}$ dosing structure and dosing structure are made of silicon carbide to increase stiffness, reduce weight and prevent deformation at low temperatures. The optical elements are in a composite light shield and are mounted with titanium and fiberglass for thermal insulation. The total weight is $8.6 \mathrm{~kg}$, the OTA tube weighing about $5.6 \mathrm{~kg}$ (12lb) for one of the largest silicon-carbide telescopes flying at that time (now overtaken by Herschel). For viewing on public sites, 12 bit per pixel LORRI images are converted to JPEG images at 8 pixels per pixel. These public images do not contain the full range of brightness information available from raw LORRI image files.

Solar Wind Through Pluto (SWAP) is a toroidal electrostatic analyzer and a potential delay analyzer (RPA), one of the two instruments, including Plasma New Horizons and a Speakometer High Peak, the other being PEPSSI. SWAP measures particles of up to 6.5 $\mathrm{keV}$ and, due to the weak solar wind at Pluto's distance, the instrument is designed with the largest opening of any such instrument ever flown.

Particle Energy Spectrometer (PEPSSI) is a time sensor for flight and electron ions, one of two instruments that include PAM (New Horizons Plasma Spectrometer), the other being SWAP. Unlike SWAP, which measures particles up to $6.5 \mathrm{keV}$, PEPSSI increases to $1 \mathrm{MeV}$.

Alice is an ultrasound imaging spectrometer, one of two photographic tools, including the New Horizons Pluto Exploration Remote Sensing Investigation (PERSI) remote sensing; the other being the Ralph telescope. Solves bands with a wavelength of 1024 in the last and extreme ultraviolet (from 50-180 nm), over 32 viewing fields. Its purpose is to determine the composition of 
Pluto's atmosphere. This Alice instrument is derived from another Alice ship on ESA's Rosetta ship.

The 75-mm diaphragm Ralph telescope is one of the two photographic tools that make up the New Horizons Investigation (PERSI) and the other is the Alice tool. Ralph has two separate channels: MVIC (Multispectral Visible Imaging Camera), a visible CCD with wideband and color channels; Spectral Ralph was named after month Honey Alice designed by Alice.

The new horizons used LORRI to make Jupiter's first photos on September 4, 2006, from a distance of 291 million kilometers. The more detailed exploration of the system began in January 2007, with an infrared image of Callisto, as well as several Jupiter black and white images. New horizons received gravitational help from Jupiter, with the closest approach at 05:43:40 UTC on February 28, 2007, when it was 2.3 million kilometers from Jupiter. Flight increased to New Horizons at $4 \mathrm{~km} / \mathrm{s}$ $(14,000 \mathrm{~km} / \mathrm{h}, 9,000 \mathrm{mph})$, accelerated the probe at a speed of $23 \mathrm{~km} / \mathrm{s}(83,000 \mathrm{~km} / \mathrm{h}, 51,000 \mathrm{mph})$.

The flight was at the center of an intensive fourmonth observation campaign that took place between January and June. As a constantly changing scientific target, Jupiter was intermittently observed at the end of the Galileo mission in September 2003. The knowledge of Jupiter benefited from the fact that New Horizons was built using the latest technology, especially in the field of cameras, representing a significance to the improvement of Galileo's chambers, which were modified versions of the Voyager chambers, which in turn were modified by the Mariner chambers. Jupiter's encounter also served as a rehearsal of shakedown and clothing for the encounter with Pluto. Since Jupiter is much closer to Earth than Pluto, the communication link can transmit more memory storage tasks; therefore the mission returned more data from the Jovian system than it was expected to transmit from Pluto.

One of Jupiter's main objectives was to observe its atmospheric conditions and to analyze the structure and composition of its clouds. Heat losses induced by light in polar regions and "waves" indicating violent storm activity were observed and measured. The small red dot, which covers up to $70 \%$ of the Earth's diameter, was recorded almost for the first time. The various angles and lighting conditions, New Horizons, have made detailed images of Jupiter's free world and system, revealing the remnants of recent clashes or other unexplained phenomena. Looking for months undiscovered in the rings did not work. Traveling through Jupiter's magnetosphere, New Horizons gathers valuable particle readings. Plasma "Bubble", which is believed to be composed of the material ejected by moon Io, was observed in the magnetotail.

Jupiter's four largest months were in weak positions for observation; the necessary path of assistance for gravity meant that the New Horizons passed millions of miles from any of the months of Galilee. However, its tools were designed for small and small targets, so they were scientifically useful for the long and distant months. The emphasis was on the most intimate moon of Jupiter, Io, whose active volcanoes give the Jupiter magnetosphere tonal tones and beyond. Of the eleven eruptions observed, three were seen for the first time. Tvashtar has reached an altitude of up to $330 \mathrm{~km}$. The event gave scientists an unprecedented look at the structure and movement of growing snow and its subsequent fall to the surface. The infrared signals of 36 other volcanoes were observed. The Callisto surface was analyzed using LEISA, illustrating how illumination and visualization conditions affect surface readings. Minor satellites, such as Amalthea, have improved orbital solutions. The rooms have determined their positions, acting as "reverse optical navigation".

After Jupiter passed, New Horizons spent most of their journey to Pluto in hibernation mode: Redundant components, as well as guidance and control systems, were shut down to prolong the life cycle to reduce operations cost and to release the Deep Space network for other missions. During hibernation, the onboard computer monitored the probe systems and sent a signal back to Earth: A "green" code if everything worked as expected or a "red" code if mission control assistance was needed. The probe was activated for approximately two months a year so that the instruments could be calibrated and the systems checked. The first hibernation cycle started on 28 June 2007, the second cycle started on 16 December 2008, the third cycle on 27 August 2009 and the fourth cycle on 29 August 2014, after a 10-week test.

New horizons passed into Saturn's orbit on June 8, 2008 and on Uranus on March 18, 2011. After astronomers announced a new month in Pluto, Kerberos and Styx systems, mission planners began to contemplate the possibility of unexpected old ships and collisions. An 18-month study on computer simulations, telescopic observations and occult observations based on Pluto showed that the possibility of a catastrophic collision with debris or dust was less than $0.3 \%$ during probe planning. If the danger increases, New Horizons could have used one of two possible emergency plans, the so-called Safe Haven by Other Trajectories: The probe could have continued on the current trajectory with the input particle antenna, the systems would be protected or could position the antenna to make a course correction that would take it just 3,000 miles from Pluto, where the atmospheric tract is expected to clean the surrounding surface of any debris.

During hibernation in July 2012, New Horizons began collecting scientific data with SWAP, PEPSSI and VBSDC. Although initially only VBSDC was planned, other tools were propelled by the initiative of principal investigator Alan Stern, who decided to use the 
opportunity to collect valuable data about the heliosphere. Prior to the activation of the other two tools, ground tests were carried out to ensure that extensive data collection at this phase of the mission would not limit the amount of energy, memory and fuel available in the future and that all systems operate during the flight. The first set of data was submitted in January 2013 during a three week hibernation activation. The data control and data processing software has been updated to resolve the issue of restarting your computer.

Other possible targets were Trojans from Neptune. The trajectory of the probe to Pluto passed Lagrange Point ("L5"), which can accommodate hundreds of resonant resemblances of 1: 1 . At the end of 2013, New Horizons were in the 1.2 UA range $(180,000,000 \mathrm{~km}$, $110,000,000 \mathrm{mi})$ L5 Neptune 2011 HM102, identified shortly before the New Horizons KBO Search research team while searching for more distant objects for New Horizons after Pluto's 2015 meeting. This range, HM102 2011, would have been brilliant enough to be detectable by the New Horizons LORRI tool; however, the New Horizons team eventually decided that it would not target HM102 for comments, as preparations for Pluto's approach had priority.

The LORRI images from July 1 to July 3, 2013 were the first probes to solve Pluto and Charon as separate objects. On July 14, 2014, mission controllers launched a sixth trajectory (TCM) to allow the ship to reach Pluto. Between 19 and 24 July 2014, LORRI of New Horizons broke 12 Charon images, circulating around Pluto, covering a total rotation of 429 to 422 million kilometers $(267,000,000$ to 262,000,000). In August 2014, astronomers carried out high precision measurements of Pluto's position and orbit around the Sun using the Atalcama Large Millimeter/Submillimeter Array (ALMA) arc to help NASA New Horizons navigate Pluto accurately. On December 6, 2014, mission controllers sent a signal to the ship to "wake up" from the final hibernation to Pluto's approach and began regular operations. The ship's response to "awake" arrived on Earth on December 7, 2014 at 14:30 UTC.

Pluto's remote operations began on January 4, 2015. At this point, targets on the LORRI plus Ralph telescope are just a few pixels. Investigators have begun to take Pluto's background images to assist mission navigators in designing engine correction maneuvers that would accurately change the New Horizons trajectory to target the approach. On January 15, 2015, NASA presented a brief update of the approach and departure phases.

On February 12, 2015, NASA released new Pluto images (January 25 - January 31 ) from the nearby probe. The new horizons were more than 203 million kilometers away from Pluto when they began taking pictures, which he showed to Pluto and the tallest month, Charon. The exposure time was too short to observe the smaller, much weaker, months of Pluto.
Investigators took a series of photos from the Nix and Hydra months between January 27 and February 8, 2015, starting at a distance of 201 million kilometers (125 million kilometers). Pluto and Charon appear as a single overexposed object in the center. The correct image was processed to remove the background. The smallest two months, Kerberos and Styx, were seen on photos taken on April 25th. Starting May 11, a search for dangers was carried out, searching for unknown objects that could pose a threat to space ships, such as rings or moons, to avoid changing the course.

Also, as far as the January 2015 approach is concerned, the team has announced that it will spend time trying out long-distance observations of the Kuiper belt object, temporarily called VNH0004 (now called KW48 2011). 75 gigameters (0.50 UA). The object would be too distant to solve surface characteristics or to take spectroscopy, but it could make observations that can not be made from Earth, namely a phase curve and a search for small satellites. A second object was planned to be respected in June 2015 and the third in September after the flight; the team hoped to observe a dozen of such objects by 2018. On April 15, 2015, Pluto was recorded with a possible polar head.

The new horizons have passed $12,500 \mathrm{~km}$ from Pluto, this approach being the closest on July 14, 2015, at 11:50 UTC. The new horizons had a relative speed of 13.78 $\mathrm{km} / \mathrm{s}(49,600 \mathrm{~km} / \mathrm{h}, 30,800 \mathrm{mph})$ at the closest approach and reached Charon at 28,800 km (17,900 mi). Starting 3.2 days before the closest approach, long-range imaging included the mapping of Pluto and Charon at a resolution of $40 \mathrm{~km}(25 \mathrm{mi})$. This is half the rotation period of the Pluto-Charon system and allows the image of all sides of both bodies. Approximately twenty days were repeated images of proximity to looking for surface changes caused by the fall of localized snow or surface cryovolcanism. Because of Pluto's inclination, some of the northern hemispheres would always be in the shadows. During the meeting, engineers expected LORRI to get selected images with a resolution of up to $50 \mathrm{~m} /$ pixel if the nearest distance was $12,500 \mathrm{~km}$ and the MVIC would have a resolution of 1.6 kilometers. LORRI and MVIC have tried to overlap these areas to form stereo pairs. LEISA has obtained infrared hyperspectral maps at a distance of $7 \mathrm{~km} / \mathrm{px}(4.3 \mathrm{mi} / \mathrm{px})$ globally and $0.6 \mathrm{~km} / \mathrm{px}$ $(0.37 \mathrm{mi} / \mathrm{px})$ for the selected areas.

Meanwhile, Alice characterized the atmosphere, both by atmospheric emissions and diminishing backgrounds, while behind Pluton (occult). During and after the closest approach, SWAP and PEPSSI analyzed the high atmosphere and its effects on solar wind. VBSDC searched for dust, lowering meteoroid collision rates and any invisible rings. REX has made active and passive radio science. Earth Antenna measured the disappearance and reappearance of the radiant signal as 
the probe flew behind Pluto. The results solved the Pluto diameter (by synchronization) and its density and atmospheric composition (by its slimming and curing model). (Alice can perform similar occlusions using sunlight instead of radio beacons.) Previous missions have transmitted the spacecraft via the Earth ("downlink"). The distribution of masses and masses in Pluto was assessed by the spacecraft gravity tug. As the spacecraft accelerates and slows down, the radio signal has shown a Doppler shift. Doppler modulation was measured by comparison to the ultrastable oscillator in communications electronics.

It is also used for sophisticated reconnaissance missions whose objective is to link the study of several planets or moons (Voyager probes, Fig. 4). Finally, it may be the only way to study minor objects - comets and asteroids - whose relative speed is too great to allow go into orbit (Stardust mission).

The Voyager program is an American science program that uses two robotic probes, Voyager 1 and Voyager 2, to study the outdoor solar system. The probes were launched in 1977 to take advantage of a favorable alignment of Jupiter, Saturn, Uranus and Neptune. Although their initial mission was to study only the planetary systems of the planets Jupiter and Saturn, Voyager 2 continued with Uranus and Neptune. Voyagers are now exploring the outer boundary of the heliosphere in interstellar space; their mission has been extended three times and continues to provide useful scientific data. Neither Uranus nor Neptune was visited by a bell, but by Voyager 2 .

On August 25, 2012, Voyager 1 data indicated that it became the first human object to enter interstellar space, traveling "more than anyone or anything else in history." Starting in 2013, Voyager 1 moved to the Sun at a speed of 17 kilometers per second $(11 \mathrm{mi} / \mathrm{s})$.

On November 5, 2018, data from Voyager 2 indicated that it also entered interstellar space.

Data and photographs made by cameras, magnetometers and other Voyager tools revealed unknown details about each of the four giant planets and their moons. The images of the nearby spacecraft were complex forms of clouds, winds and storms of Jupiter and discovered a volcanic activity per month. Saturn's rings have been discovered to have enigmatic spaces, scratches and peaks and have been accompanied by countless "straps." At Uranus, Voyager 2 discovered a substantial magnetic field around the planet and another ten months. His field in Neptune discovered three rings and six months previously unknown, a complex and widespread magnetic field. Voyager 2 is the only spacecraft to visit the two ice giants. In August 2018, NASA confirmed, based on the results of the spacecraft New Horizons, a "hydrogen wall" at the outer edge of the solar system, first detected in 1992 by the two spacecraft Voyager.

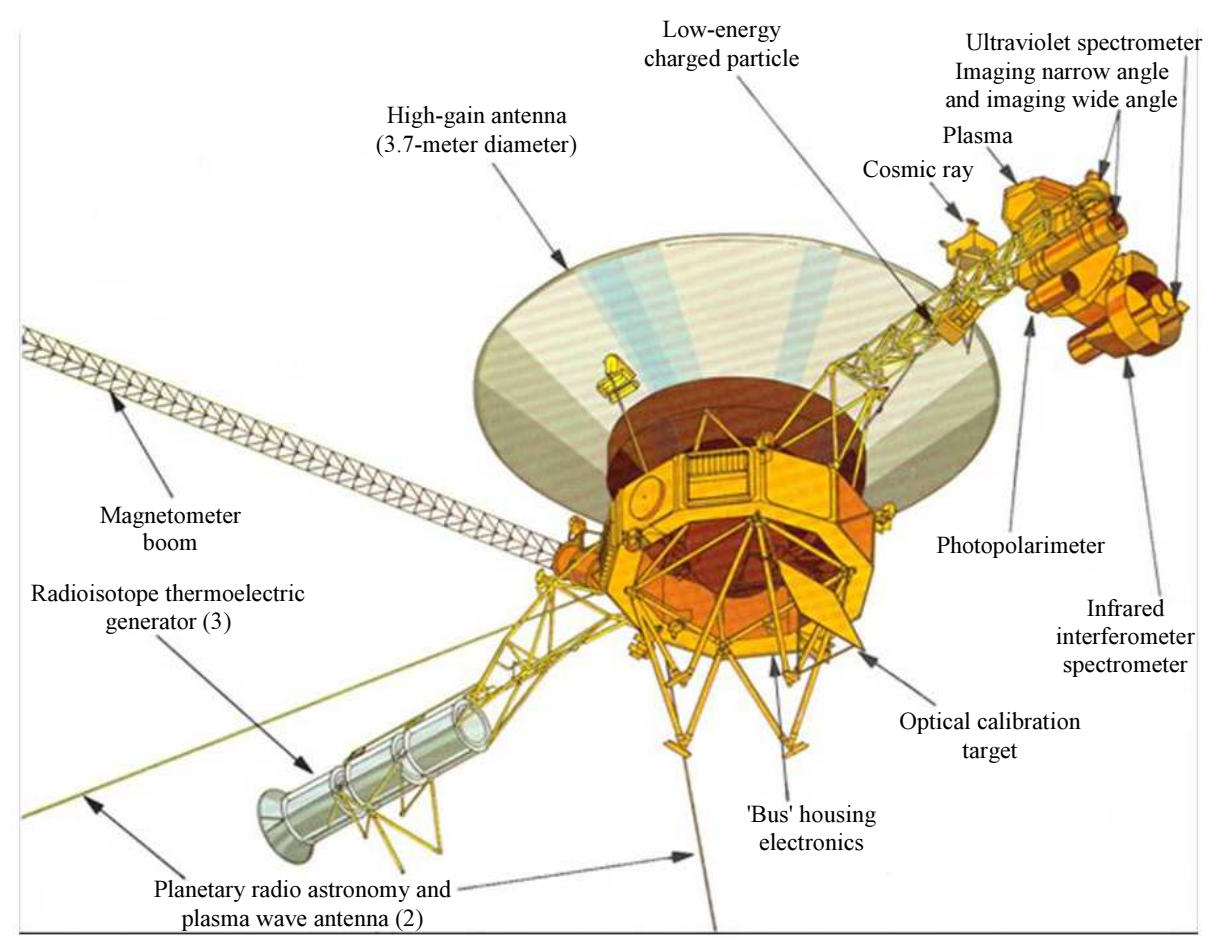

Fig. 4: Voyager probes 
Voyager Spacecraft was built at South California's Jet Propulsion Laboratory and funded by Cape Canaveral, funded by NASA, Florida, following all the other wells.

The initial cost of the program was $\$ 865$ million and the initial cost of the Voyager Interstellar program cost an extra $\$ 30$ million.

The two Voyager probes were originally designed as part of the Mariner program and were originally called Mariner 11 and Mariner 12. They were then moved to a separate program called "Mariner Jupiter-Saturn", renamed the Voyager Program by Design Thinking Two Ship have progressed much more than the Mariner family to deserve a separate name.

The Voyager program was similar to that of the Grand Planet tournament planned in the late 1960s and early 1970s. The Grand Tour will take advantage of the alignment of the exterior plans discovered by Gary Flandro, an aerospace engineer at the Jet Propulsion Laboratory. This 175-year alignment will take place in the late $1970 \mathrm{~s}$ and will make it possible to use gravitational assistance to explore Jupiter, Saturn, Uranus, Neptune and Pluto. The planet's big tournament was to send more pairs of probes to fly on all outer planets (including Pluto, then considered a planet) on different trajectories, including Jupiter-Saturn-Pluto and Jupiter-Uranus-Neptune. Limited funding has completed the Grand Tour program, but they have been included in the Voyager program, which has met many of the Grand Tour's flight objectives, except for a visit to Pluto.

Voyager 2 was the first to release. Its trajectory was designed to allow Jupiter, Saturn, Uranus and Neptune flights. The Voyager 1 was launched after the Voyager 2 but on a shorter and faster trajectory designed to provide the optimal Saturn navigation, Titan, known to be quite large and possess a dense atmosphere. This meeting sent Voyager 1 out of the ecliptic plane, ending his planetary scientific mission. If Voyager 1 could not fly to Titan, the Voyager 2 trajectory could have been modified to explore Titan by giving up any visit to Uranus and Neptune. Voyager 1 was not launched on a trajectory that would allow them to continue on to Uranus and Neptune but could have gone from Saturn to Pluton without exploring Titan.

In the 1990s, Voyager 1 passed the slowest spacecraft Pioneer 10 and Pioneer 11 to become the farthest human object on earth, a record that will keep it in the near future. The New Horizons probe, which had a higher launch speed than Voyager 1, travels slower with the Voyager 1 supplement from Jupiter and Saturn. Voyager 1 and Pioneer 10 are the most often separate human objects from anywhere moving in opposite directions to the solar system.

In December 2004, Voyager 1 experienced the final shock, where the solar wind slowed to subsonic speed and entered the heliosheath where the solar wind is compressed and turbulent due to interactions with the interstellar environment. On Dec. 10, 2007, Voyager 2 also reached the termination shock, about 1 billion miles closer to the Sun than the one in which the first Voyager 1 passed, indicating that the solar system is asymmetric.

In 2010, Voyager 1 reported that the outside speed of the solar wind has fallen to zero and scientists have predicted that it is approaching interstellar space. In 2011, Voyager data found that the heliosheath is not smooth but filled with huge magnetic bubbles, theorized to form when the Sun's magnetic field becomes deformed to the edge of the solar system.

On June 15, 2012, NASA scientists reported that Voyager 1 was very close to entering the interstellar space, indicated by a sharp increase in high energy particles outside the solar system. In September 2013, NASA announced that Voyager 1 crossed the heliopause on August 25, 2012, becoming the first spacecraft to enter the interstellar space.

In December 2018, NASA announced that Voyager 2 crossed the heliopause on November 5, 2018, becoming the second spacecraft to enter interstellar space.

Starting in 2017, Voyager 1 and Voyager 2 continue to monitor the external conditions of the solar system. It is assumed that the spacecraft Voyager will be able to operate scientific instruments by 2020 when a limited power will require disarmament tools one by one. Sometime, around 2025, there will be little power to operate any scientific instrument.

Voyager spacecraft each weigh 773 pounds $(1,704$ pounds). Of this total weight, each spacecraft transported 105 kilograms (231 kilograms) of scientific instruments. The same spacecraft uses three-axis stabilized guidance systems using gyro and accelerometer inputs for their attitude control computers to straighten terrestrial antennas and their scientific instruments to their targets, sometimes with the help of a small mobile platform and digital systems digital.

The diagram shows the High-heeled Antenna (HGA) with a $3.7 \mathrm{~m}(12 \mathrm{ft})$ diameter vessel attached to the empty decanter. There is also a spherical reservoir containing hydrazine propellant monohydrate.

The Gold Voyager record is attached to one of the sides of the bus. Square-square to the right is the optical calibration target and the excessive heat radiator. The three radioisotope thermoelectric generators (RTGs) are mounted at the end of the lower arm.

The scanning platform Includes Infrared Interferometer (IRIS) spectrometer (upper chamber); Ultraviolet (UVS) just above IRIS; the two Vidicon video cameras (ISS); and the Photopolarimeter System (PPS) within the ISS.

Only five investigative teams are still accepted, although data is collected for two additional tools. The Data Flight Subsystem (FDS) and a single digital device (DTR) offer data processing functions. 
FDS configures each instrument and controls the operations of the instrument. It also collects engineering and science data and forms data for transmission. DTR is used to record a High-Speed Waveguide (PWS) subsystem. The data are presented every six months.

The Imaging Science Subsystem made up of a wide angle and a narrow-angle device, is a modified version of the Vidicon slow scanning models that were used in previous Mariner flights. The Imaging Science Subsystem consists of two television cameras, each with eight filters in a commendable filter wheel mounted in front of the vidicon. One has a small lens size of $200 \mathrm{~mm}$ wide ( 7.9 inches) with an $\mathrm{f} / 3$ (wide angle) lens, while the other uses a resolution of more than $1500 \mathrm{~mm}$ with f/narrow-angle camera).

Voyager's primary mission was completed in 1989 with Neptune's close flight by Voyager 2. The Voyager Interstellar (VIM) mission is a prolongation of the mission that began when the two ships disappeared for over 12 years. The Heliophysics Division of the Heliophysics Division made a top magazine for heliophysics in 2008. The group found that VIM "is an absolutely imperative mission to continue" and that VIM funding is approaching the optimal level and increase in the number of DSNs. "

The main objective of the VIM is to extend the exploration of the solar system beyond the outer planets to the outer boundary and, if possible, even beyond it. Voyagers continue to search for the limit of the heliopause, which is the outer limit of the Sun's magnetic field. Passing through the limit of heliopause will allow the spacecraft to measure interstellar fields, particles and waves that are not affected by the solar wind.

The entire Voyager 2 scan platform, including all platforms, was shut down in 1998. All tools on the Voyager 1 platform, except the Ultrasound (UVS) spectrometer, were also closed.

The Voyager 1 scanning platform was scheduled to take off at the end of 2000 but was left to investigate the UV emission from the wind. UVS data is still captured, but scans are no longer possible.

Gyro activities were completed in 2016 for Voyager 2 and 2017 for Voyager 1. Gyro operations are used to rotate the 360-degree probe six times a year to measure the magnetic field of the spacecraft, which is then removed from the science of the magnetometer.

The two spacecraft continue to operate, with some losses in subsystem redundancy, but retain the ability to return scientific data from the completion of the Voyager Mission Mission Interstellar (VIM) mission.

Both ships also have adequate power and propulsion control to continue to operate until around 2025, after which there can be no electricity to support the functioning of scientific instruments; the return of scientific data and the operations of spacecraft will cease.
At the beginning of VIM, Voyager 1 was 40 AA from Earth, while Voyager 2 was at 31 AU. VIM has three phases: Final shock, heliosheath exploration, interstellar exploration phase. Spacecraft launched VIM in a medium controlled by the Sun's magnetic field, the plasma particles being dominated by the supersonic wind. This is the characteristic of the final shock phase. At a certain distance from the Sun, the supersonic solar wind will be prevented by the later expansion of the interstellar wind. The first feature encountered by a spacecraft as a result of this interstellar solar-solar interaction was the final shock if the solar wind slowed to subsonic speed and there were large changes in the direction of plasma flux and magnetic field orientation.

Voyager 1 finished the last shock phase in December 2004 at a distance of $94 \mathrm{AU}$, while Voyager 2 finished in August 2007 at a distance of 84 AU. After entering the heliosheath, the spacecraft is in an area dominated by the Sun's magnetic field and solar wind particles. After crossing the heliosheath, the two voyagers will begin the interstellar exploration phase. The outer limit of heliosheath is called heliopause, where the spacecraft is now. This is the region where the influence of the Sun begins to decrease and the interstellar space can be detected. Voyager 1 escapes from the solar system at a rate of 3.6 AU per year, 35 degrees north of the ecliptic in the general direction of the Hercule peak, while the Voyager 2 is about 3.3 AU per year at 48 degrees south of the ecliptic. The Voyager of the ship will eventually get to the stars. In about 40,000 years, Voyager 1 will be below 1.6 light (LY) of AC +793888 , also known as the Gliese 445, which is approaching the sun. At 40,000 years, the Voyager 2 will be within 1.7 liters of Ross 248 (another star approaching the sun) and in 296,000 years will pass into 4.6 liters of Sirius, the brightest star of the night sky.

An orbiter is a space probe that, having transited to its goal, orbits around the celestial body to be studied. This is the second major category of space probes with those overflights. To be able to go into orbit, the spacecraft must greatly reduce its speed when it arrives close to its objective. The propellants used for this braking operation can represent a significant fraction of the total weight of the vehicle (typically around $50 \%$ for Mars). The orbiter allows regular observations of almost the entire surface of the celestial body for several years. The orbiter is the step that logically follows the sending of a probe performing a simple overflight. The orbit of the space probe is chosen according to the objectives pursued but also to mass constraints. Missions with a constrained budget like Mars Express will choose a less efficient but less expensive elliptical orbit propellant than a low circular orbit retained for the majority of NASA's Martian orbiters. 
An atmospheric probe is a space probe that crosses the atmosphere of a planet to study it. Its mission is relatively brief since it usually lasts the time of its descent (not propelled) to the ground. During this phase, it only needs a limited amount of energy, so it pulls batteries. The atmospheric probe is usually transported to the planet explored by a mother ship. The planet Venus has been studied in particular by this method with the series of Soviet probes of the Venera program. Other notable atmospheric probes are Huygens who studied the atmosphere of Titan, the atmospheric probe of Galileo that plunged into the upper layers of the giant gas planet Jupiter. The very thick atmosphere of Venus allowed the implementation of the balloons of the program Vega Soviet which could transmit data for several tens of hours.

An undercarriage is a type of spacecraft designed to survive the landing on the ground of a planet or moon and then collect with its scientific instruments data on the surface that is transmitted to the Earth directly or indirectly (via another spacecraft in orbit). The Moon and the Mars planet have been particularly explored by spacecraft of this type with for example the probes of the Surveyor program the two probes of the Viking program or the Phoenix lander. The soft landing is the main difficulty faced by designers of this type of gear. The use of a parachute, implemented for example by Huygens on Titan, requires the presence of a sufficiently thick atmosphere and is therefore not suitable for Mars. Reduced mass and cost compared to other methods, the parachute does not allow a completely controlled landing.

To land on celestial bodies devoid of atmosphere, it is necessary to resort to rocket engines which gradually reduce the speed of the spacecraft. These, however, require the carriage of a large amount of fuel. For Mars, NASA has developed special landing techniques: The airbags first implemented by Mars Pathfinder and a highly sophisticated one-stage ground-level landing system, implemented as a "flying crane". 2012 by Mars Science Laboratory probe.

An astro-mobile or rover after landing on the ground of a celestial body moves to carry out studies in situ in different points of scientific interest. It can carry real small laboratories to analyze collected samples like Mars Science Laboratory. Its energy can be produced by solar panels or RTGs. It is remote controlled if the distance is not too important (Moon).

On the other hand, the distance is too important for the Martian rovers and they have a certain autonomy for their displacements which relies on programs of analysis of the ground. The movements on a day do not exceed a hundred meters.

A sample return mission is to bring samples of another celestial body - planet, comet, the asteroid - or interplanetary or interstellar particles back to Earth for analysis.
Compared to an on-site study by robot instruments like the Curiosity Martian rover, returning a soil sample to Earth allows much more accurate analysis, manipulation of the sample and to modify the experimental conditions as the progress of technology and knowledge progresses.

This type of mission involves major difficulties: It is necessary, depending on the target, to capture particles traveling at several $\mathrm{km} / \mathrm{s}$, to make an automatic landing on a body practically devoid of gravity or, on the contrary, to be able to land and take off again from a well of serious gravity and in all cases, return to the Earth's atmosphere at high speed and with great precision. The return to Earth of Martian soil samples, which in 2016 is one of the most important objectives for the study of the solar system, has still not been realized for both financial and technological reasons.

An indenter is a small spacecraft designed to penetrate the ground of a celestial body (planet, moon, asteroid or comet) at high speed undergoing a deceleration of several hundred grams. The information gathered by onboard scientific instruments is traditionally transmitted by a small transmitter to the orbiting parent ship which in turn transmits it to stations on Earth.

The concept of the indenter makes it possible to avoid the carrying of parachutes and rockets necessary for a soft landing and thus to lighten the mass of the undercarriage considerably. But it must be able to withstand the impact which in turn creates many constraints on its mass, its structure and the design of its payload.

Several penetrator projects have not gone beyond the study phase and, in 2013, only two missions have implemented penetrators with no results due to the loss of motherships: Two Deep Space 2 penetrators were onboard Mars Polar Lander and two others on board March 96.

A telecommunications satellite responsible for relaying communications between the surface of a celestial body where there is a lander or a rover and the Earth. These devices have until now always been orbits having their own scientific goals such as the 2001 Mars Odyssey or Mars Reconnaissance Orbiter. Some space probes fall into several categories such as Viking probes that have both landing gear and an orbiter.

A technological demonstrator is a spacecraft whose objective is to validate a new technique. For example, Deep Space 1 whose main objective was to validate the use of ion propulsion for interplanetary missions.

To operate a space probe needs to have energy permanently.

The recently developed machines must have an electrical power between 300 and 2500 watts to power onboard computers, radio transceiver, motors, scientific instruments, radiators and much other equipment. There are only three possible sources of energy for an interplanetary spacecraft: Solar panels, 
RTGs only solutions for external planets too far from the Sun and batteries.

These can be a source of energy charged before launch or be used as a temporary energy storage system produced by solar panels to cope for example periods of an eclipse.

Solar panels consist of a set of photovoltaic cells that each transform solar energy by photoelectric effect into a continuous electric current. Each solar cell consists of a semiconductor material connected with electrical connections. Several types of materials can be used such as silicon or GaAs more efficient but more expensive. The most efficient cells consist of several very thin layers of semiconductor materials, each capable of converting a large part of the spectrum of solar energy, which makes it possible to achieve, in combination with other devices, a $47 \%$ (47\% of the Sun's energy is converted into electrical current). The solar cell yield of the early 1960 s satellites was $6 \%$.

By connecting the solar cells in series (the positive pole of one cell is connected to the negative pole of another cell) the voltage of the product current is increased, while connecting them in parallel (all the positive poles are connected together and all the negative poles are connected together) the intensity of the current is increased. The solar panel serves as physical support for the solar cells, has the electrical circuits connecting the cells together and keeps the cells in an acceptable temperature range. Several solar panels can be connected together to form a "wing".

Generally, solar panels are articulated and their orientation can be changed with one or two degrees of freedom. Generally, by constantly changing the inclination of the solar panels, it is sought to obtain as the case the maximum energy if we make sure that the sun's rays strike perpendicular to the panel. But this facility can also be used to reduce the angle of incidence of the solar rays in order to limit the rise in temperature or to adapt the production of current to a weaker demand (the electrical energy produced decreases like the cosine of the angle incidence of solar rays). On a spinned probe, the solar panels line the body of cylindrical shape and the half is in the shade while the majority of the cells do not receive the Sun under an optimum angle.

At the Earth's orbit, the theoretically available electrical energy is $1,371 \mathrm{~W} / \mathrm{m}^{2}$, of which $50 \%$ can be converted into electrical energy with the most advanced solar cells. Abundant at the level of the inner planets, the quantity of energy available is inversely proportional to the square of the distance to the Sun.

Thus a probe like Juno sent into orbit around Jupiter five times farther from the Sun than Earth receives 25 $(5 \times 5)$ times less solar energy than at Earth. NASA has nevertheless chosen to equip this probe with solar panels that thanks to their surface $\left(45 \mathrm{~m}^{2}\right.$ of solar cells) and their advanced technology manage under these conditions to provide 428 watts (and $15 \mathrm{~kW}$ at the Earth's orbit). But at this distance from the Sun, the use of RTG is more frequent.

The performance of solar panels of a space probe degrades under the action of several phenomena. The energy received by the solar panel that is not converted into electrical energy is partly reflected and partly converted into heat which increases the temperature of the cells. When its temperature increases the solar cell produces a current of higher voltage but the amperage decreases as well as the power produced $(\mathrm{W}=\mathrm{V} \times \mathrm{I})$. This decrease in overall performance is $1 \%$ per degree Celsius for silicon cells and $0.5 \%$ for cells in GaAs. Moreover, a few hundred hours after its deployment, the performance of a solar panel decreases by $1 \%$ due to the chemical changes generated by the light. Finally, the factor that produces the most damage is the action of energy particles produced by the solar wind or solar storms that progressively damage the crystalline structure. Thus the solar panels of the Magellan probe, placed in orbit around Venus, lost two-thirds of their capacity during their operational life.

This progressive degradation is taken into account in the design of the solar panels at the time of the design of the space probe.

When the solar energy becomes too weak because of the distance of the Sun one or more thermoelectric generator with radioisotope replaces the solar panels for the production of electricity. This electric generator produces electricity from the heat released by the radioactive decay of materials rich in one or more radioisotopes, usually plutonium 238 in the form of plutonium dioxide $238 \mathrm{PuO} 2$. The heat is converted into electricity via thermocouples.

The energy efficiency is reduced: Less than $10 \%$ of the heat produced is converted into electricity and the rest must be evacuated by radiators. To improve this performance, current research is moving towards thermo in toroidal converters and Stirling radioisotope generators, which could multiply the overall efficiency by four but would impose moving mechanical parts that can become blocked over time. The thermoelectric radioisotope generator is particularly well suited to producing a stable power supply, over a long time required for the instruments embedded in the interplanetary probes. Thus, the generator on the New Horizons probe is able to provide a stable power supply of $200 \mathrm{~W}$ over more than 50 years.

However, the presence of plutonium 238 in a machine likely to be the victim of a launcher failure, raises strong fears in part of the public opinion despite protective devices (shielding) which have proved in practice effective. 


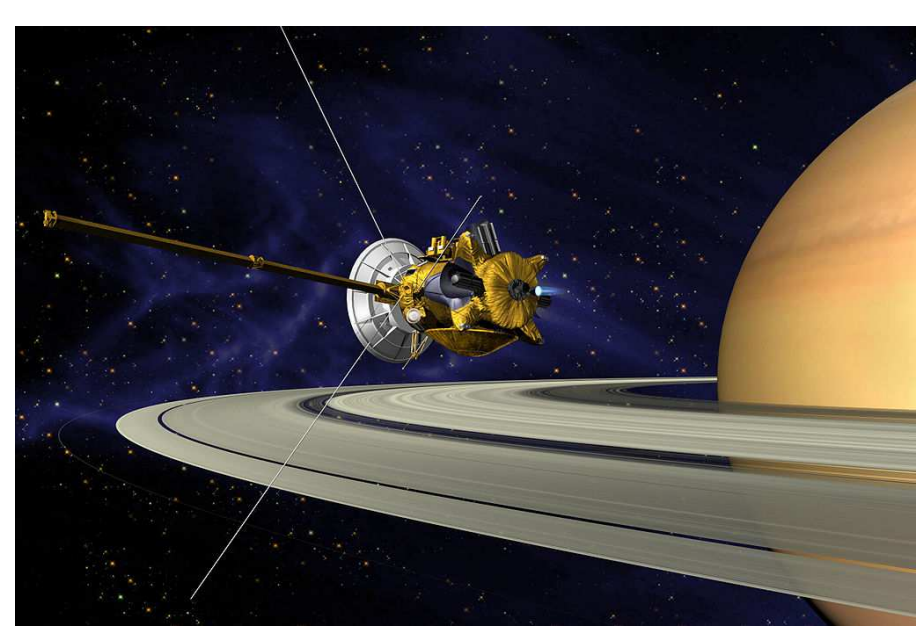

Fig. 5: Cassini

Space probes launched to Jupiter or beyond such as Voyager 1, Cassini (Fig. 5) or New Horizons use thermoelectric radioisotope generators for their power supply.

The Cassini-Huygens mission, commonly referred to as Cassini, was a collaboration between NASA, the European Space Agency (ESA) and the Italian Space Agency (ASI) to send a test to study the planet Saturn and its satellite system. The oldest robotic spacecraft includes both NASA's Cassini probe and ESA's Huygens soil, which landed Titan's biggest month. Cassini was the fourth space probe to visit Saturn and the first to enter his orbit. Botites were named by astronomers Giovanni Cassini and Christiaan Huygens.

Launched on a Titan IVB/Centaur on October 15, 1997, Cassini has been active in space for nearly 20 years, 13 years in orbit on Saturn, studying the planet and its system after it enters orbit on July 1, 2004 (Trip to Saturn Venus flights, April 1998 and July 1999, Earth August 1999, asteroid 2685 Masursky and Jupiter December 2000). His mission ended on September 15, 2017, when Cassini's trajectory led to Saturn's upper atmosphere and burned to prevent any risk of Saturn's contamination, which could have provided living environments to terrestrial microbes on the space ship. The mission is widely perceived as successful beyond expectations. Cassini-Huygens was described by NASA's planetary scientist as a "rewarding mission" that revolutionized Saturn's human understanding, including its moons and rings, as well as our understanding of the place where life is in the solar system.

Cassini's initial mission was scheduled to last for four years, from June 2004 to May 2008. The mission was extended for two more years until September 2010, marking the Cassini Equinox mission. The mission was expanded for the second time and last time for the Cassini Solstice mission, which lasted seven years until
September 15, 2017, when Cassini was willing to burn into Saturn's upper atmosphere.

The Huygens module traveled with Cassini until its probe was disconnected on December 25, 2004; was landed on Titan on January 14, 2005. He returned the data to Terra for about 90 minutes, using the relay as a relay. This was the first landing ever made in the outer solar system and the first landing in a month other than the Earth's Moon.

At the end of his mission, the Cassini crew executed the "Great Finale" of his mission: A series of risky passes through Saturn's gap with Saturn's inner rings. The purpose of this phase was to maximize Cassini's scientific results prior to the destruction of the spacecraft. Cassini's atmospheric inputs ended the mission, but the return of the data returned will continue for many years.

Teams from 28 countries formed the joint team responsible for designing, building, flying and collecting data from Cassini and Huygens.

The mission was managed by the NASA Jet Propulsion Laboratory in the United States where the orbit was assembled. Huygens was developed by the European Center for Space Research and Technology. The main contractor of the Aérospatiale Center in France (now Thales Alenia Space) has assembled the probe with equipment and instruments provided by many European countries (Huygens batteries and two US scientific instruments). The Italian Space Agency (ASI) has provided a Cassini orbiter radio antenna with the incorporation of a low gain antenna (to provide Earth telecoms during the mission), a compact and easy radar, using radar antenna synchronization, radar altimeter, RSS radio subsystem) in the VIMS-V channel of the VIMS spectrometer.

The VIMS infrared counterpart was provided by both NASA and the Main Electronic Assembly, which includes electronic subassemblies provided by CNES in France. 
On April 16, 2008, NASA announced a two-year extension of ground operations for this mission when it renamed the Cassini Equinox mission. The funding round was once again expanded in February 2010 with the Cassini Solstice Mission.

Cassini had several goals, including:

- Determination of the three-dimensional structure and dynamic behavior of the Saturn rings

- Determining the composition of the satellite surfaces and the geological history of each object

- Determining the nature and origin of dark matter in the Iapetus hemisphere

- Measurement of the three-dimensional structure and dynamic behavior of the magnetosphere

- Studying the dynamic behavior of Saturn's atmosphere at cloud level

- Studying the time variability in the clouds and dangers of Titan

- Characterization of the Titan surface on a regional scale

Cassini-Huygens was launched on October 15, 1997, from the Cape Canaveral Space Force spacecraft, using the US Air Force Titan IVB/Centaur aerial force. The complete launch consisted of a Titan IV two-speed rocket, two solid rocket engines on the belt, the Centaur support gear and a useful shield or a useful shield.

The total cost of this exploration mission was about \$ 3.26 billion, including $\$ 1.4$ billion for development before launch, \$ 704 million for mission operations, \$ 54 million for tracking and $\$ 422$ million for vehicles that start. The United States has contributed \$ 2.6 billion (80\%), \$ 500 million (15\%) and \$ 160 million (5\%). However, these figures come from the press kit drafted in October 2000. They do not include inflation during a very long mission and do not include the cost of extensive missions.

Cassini's primary mission was completed on July 30, 2008. The mission was extended until June 2010 (Cassini Equinox Mission). This has studied the Saturn system in detail during the planet's equinox, which happened in August 2009.

On February 3, 2010, NASA announced a new extension for Cassini, which lasted six and a half until 2017, ending Cassini solo solo solo Cassini in summer. The extension allowed another 155 revolutions around the planet, 54 Titan flights and 11 flights from Enceladus. In 2017, a meeting with Titan changed the orbit so close to Saturn that it was just 3,000 miles above the planet's clouds below the inner edge of the ring D. This sequence of "proximal orbits" ended when the last encounter with Titan Saturn sent the atmosphere to the probe to be destroyed.
The origins of Cassini-Huygens date back to 1982 , when the European Foundation for Science and the American Academy of Sciences formed a working group to investigate future co-operation missions. Two European scientists have suggested that a pair of Saturn Orbiter and Titan Probe could be a possible joint mission. In 1983, the NASA Solar System Exploration Committee recommended the same pair of Orbiter and Probe probes as a basic NASA project. NASA and the European Space Agency (ESA) conducted a joint study of the potential mission from 1984 to 1985. ESA continued its own study in 1986, while American astronomer Sally Ride, in his influential report of 1987 , led the future NASA US Cassini mission.

While Ride's report described Saturn's orbit and probe as a NASA solo mission, the Len Fisk associate space administrator reverted to the idea of a joint NASA and ESA mission in 1988. He wrote to ESA counterpart Roger Bonnet, strongly suggesting that ESA chose Cassini's mission from the three candidates at hand and promises that NASA will engage in a mission as soon as ESA has done so.

At that time, NASA became more sensitive to the strain that emerged between US and European space programs as a result of European perceptions that NASA did not treat it as equality during previous collaborations. The NASA authorities and advisers involved in the promotion and planning of Cassini-Huygens attempted to correct this trend, highlighting the desire to equally share the scientific and technological benefits of the mission. In part, this new spirit of co-operation with Europe was driven by a sense of competition with the Soviet Union, which began to cooperate more closely with Europe, while ESA withdrew from NASA. In 1988, ESA chose Cassini-Huygens as the next major mission and in the following year, the program received major funding in the US.

Collaboration not only improved the relationship between the two space programs but also helped CassiniHuygens survive the US Congress budget cuts. CassiniHuygens fired in 1992 and 1994, but NASA convinced the US Congress that it would not be wise to stop the project after ESA had already poured funds into development because frustration with space exploration promised that breaks could become relationship areas external. The project has continued to be politically problematic since 1994, although groups of citizens concerned about the potential environmental impact have tried to derail it through protests and trials until its launch in 1997.

The ship was planned to be the 2nd Marine II, stabilized with three axes, equipped with RTG, a class of spacecraft developed for missions beyond the orbit of Mars. Cassini was developed simultaneously with Comet Rendezvous Asteroid Flyby (CRAF), but budget cuts and reorganization projects forced NASA to stop 
CRAF development to save Cassini. As a result, Cassini became more specialized. The Mariner Mark II series has been canceled.

The Orbiter and the combined probe are the third of the largest unmanned spacecraft, interplanetary, successfully launched behind Phobos 1 and 2 Mars, among the most complex. The Orbiter had a $2150 \mathrm{~kg}$ $(4740 \mathrm{lb})$ mass, a $350 \mathrm{~kg}(770 \mathrm{lb})$ probe. With a launch engine of $3132 \mathrm{~kg}(6905 \mathrm{lb})$ and propulsion engines at launch, the ship had a mass of $5,600 \mathrm{~kg}(12,300 \mathrm{lb})$.

The Cassini ship's way was 6.8 meters $(22 \mathrm{ft})$ high and 4 meters $(13 \mathrm{ft})$ wide. The complexity of space has been increased by its trajectory (the flight path) to Saturn and the ambitious science at the destination. Cassini had 1,630 interconnected electronic components, 22,000 wire connections and 14 kilometers of cables. The CPU of the central control computer was a redundant MIL-STD$1750 \mathrm{~A}$ system. The main propulsion system consisted of an R-4D with a primary bipolar and reserve missile. Engine power was 490 newtons and the delta-v was about 2040 meters per second. Smaller rockets with propulsion have provided control of attitude.

Cassini was fed with $32.7 \mathrm{~kg}$ of plutonium-238 - the heat of radioactive degradation of the material was transformed into electricity. Huygens was supported by Cassini during a cruise but used chemical batteries when he was independent.

The probe contained a DVD of more than 616,400 signatures from citizens in 81 countries, collected in a public campaign.

Until September 2017, the Cassini probe continued on orbit Saturn at a distance of 8.2 and 10.2 astronomical units on Earth. It took 68 to 84 minutes for radio signals to travel from Earth to spacecraft and vice versa. So, ground controllers could not provide "real-time" instructions for day-to-day operations or unexpected events. Even if the answer was correct, it should have been more than two hours before a problem occurred and the satellite engineers received the answer.

Cassini's measuring instruments consisted of: A diaphragm synthetic radar mapping, an imaging system with charge devices, a visible/infrared recording spectrometer, a composite infrared spectrometer, a cosmic dust analyzer, a radio experiment and a spectrometer with plasma, plasma spectrometer, ultraviolet imaging spectrograph, magnetosphere imaging instrument, a magnetometer and an ion/neutral mass spectrometer. Telemetry from the communications antenna and from other special transmitters (an S-band transmitter and a dual frequency band system) has also been used to observe Titan's and Saturn's atmospheres and to measure the gravitational fields of the planet and its satellites.

CAPS was an in-situ instrument that measures the flow of charged particles at the spacecraft's location, depending on direction and energy. The ionic composition was also measured using a time-to-flight mass spectrometer. CAPS measured the particles produced by ionizing the molecules in the Saturn and Titan ionospheres, as well as the Enceladus chickens. CAPS has also investigated plasma in these areas, along with solar wind and interaction with Saturn's magnetosphere. CAPS was closed in June 2011 as a precaution because of a "soft" shortcut that appeared in the tool. He has fired again in March 2012, but after 78 days another deficit forced the instrument to be permanently closed.

The CDA was an in-situ instrument that measured the size, velocity and direction of small particles of dust near Saturn. It could also measure the chemical elements of the berries. Some of these particles have blinded Saturn, while others have come from other star systems. CDA in orbit was designed to learn more about these particles, materials from other heavenly bodies and possibly the origins of the universe.

CIRS was a remote detection tool that measures infrared radiation in objects to learn about temperatures, thermal properties and compositions. Throughout the Cassini-Huygens mission, CIRS measured infrared emissions from the atmosphere, rings and surfaces of the vast Saturn system. He mapped the atmosphere of Saturn in three dimensions to determine the temperature and pressure profiles with altitude, gas composition and aerosol and clouds distribution. He also measured the thermal characteristics and composition of satellite surfaces and rings.

INMS was an in situ instruments that measured the composition of charged particles (protons and heavier ions) and neutral particles (atoms and molecules) near Titan and Saturn to learn more about their atmosphere. The instrument used a quadrupole mass spectrometer. INMS has also been designed to measure the positive and neutral ionic environments of satellites and rings frozen by Saturn.

ISS was a remote detection tool that captured most of the images in visible light, as well as some infrared images and ultraviolet images. SIS took hundreds of thousands of images of Saturn, its rings and satellites. The ISS system has both a Wide-Angle Camera (WAC) and a Narrow-Angle Camera (NAC). Each of these cameras used an electromagnetic wave (CCD) sensor. Each CCD had a pixel matrix of $1024,12 \mu \mathrm{m}$ on one side. Both cameras allow many data collection modes including chip compression and have been equipped with spectral filters that rotate on a wheel to see different bands in the electromagnetic spectrum from 0.2 to $1.1 \mu \mathrm{m}$.

MAG was an in situ instruments that measured the strength and direction of the magnetic field around Saturn. The magnetic fields are partly generated by the melted core in the center of Saturn. Measurement of the magnetic field is one of the ways of exploring the nucleus. MAG aimed to develop a three-dimensional model of Saturn's magnetosphere and to determine 
Titan's magnetic state and atmosphere as well as frozen satellites and their role in Saturn's magnetosphere.

MIMI was both an in-situ and remote detection tool that produces images and other data about particles trapped in the giant magnetic field or Saturn's magnetosphere. The in-situ component measured energy ions and electrons, while the remote detection component (ionic and neutral camera, INCA) was a neutral energy imager. This information was used to study the general configuration and dynamics of the magnetosphere and its interactions with the solar wind, the atmosphere of Saturn, Titan, rings and frozen satellites.

The onboard radar was an active and passive detection tool that produced maps of Titan's surface. The radar waves were strong enough to penetrate into the thick veil of fog surrounding Titan. By measuring the time of sending and returning signals, it is possible to determine the height of large surface features such as mountains and canyon. The passive radar listened to the radio waves that Saturn or its moons can emit.

RPWS was an on-site tool and a remote detection tool that receives and measures radio signals from Saturn, including radio waves given by solar wind interaction with Saturn and Titan. The RPWS measured the fields of electric and magnetic waves in the interplanetary environment and planetary magnetospheres. It also determined the density and temperature of electrons near Titan and some regions of the Saturn magnetosphere using either waveforms in plasma at characteristic frequencies (e.g., the upper hybrid line) or a Langmuir probe. The RPWS studied Saturn's magnetic field configuration and its relationship with Saturn's Kilometer Radiation (SKR), as well as monitoring and mapping Saturn's ionosphere, plasma and lightning in Saturn's atmosphere (and possibly Titan).

The RSS was a remote detection tool that used radio antennas on Earth to see how the spacecraft's radio signals changed while they were sent through objects such as Titan's atmosphere or Saturn rings or even in the Sun's back. The RSS study also studied atmospheric and ionospheric compositions, pressures and temperatures, radial structure and particle size distribution in rings, mass and body systems and gravitational field. The instrument used the X-band communication link as well as the uplink and downlink of the S-band and tape.

UVIS was a remote detection tool that captured images of ultraviolet light reflected by an object such as Saturn's clouds and/or its rings to learn more about their structure and composition. Designed to measure ultraviolet light at wavelengths between 55.8 and 190 $\mathrm{nm}$, this instrument was also a tool to determine the composition, distribution, aerosol particle content and atmospheric temperatures. Unlike other types of a spectrometer, this sensitive instrument can take both spectral and spatial readings. He was particularly adept at determining the composition of the gases. Spatial observations have had a broad and narrow vision, with a single large pixel and 64 pixels. The spectral size was 1,024 pixels per pixel space. It could also take many pictures to create movies about how this material is moved by other forces.

VIMS was a remote detection tool that captured images using visible and infrared light to learn more about Saturn's composition and the surface of Titan's moon, ring and atmosphere. It consisted of two chambers - one used to measure visible light, the other in infrared. VIMS measured radiation reflected and emitted by atmospheres, rings and wavelengths from 350 to 5100 $\mathrm{nm}$ to determine their compositions, temperatures and structures. He also noticed the light of the sun and the light of the stars passing through the rings to learn more about their structure. Scientists have used VIMS for long-term studies on cloud movement and morphology in the Saturn system to determine Saturn's meteorological patterns.

Due to the distance between the Saturn sun, solar networks were not feasible as energy sources for this space probe. To generate enough power, such arteries would have been too big and too heavy. Instead, the Cassini orbit was fed by three Radio-isotopic thermoelectric Generators (RTGs) with natural calorific heat of approximately $33 \mathrm{~kg}$ of plutonium-238 (as plutonium dioxide) to generate direct electrical energy through thermoelectric power. Cassini X-ray has the same design as those used in the New Horizons, Galileo and Ulysses probes and designed to last a long life. At the end of the 11-year nominal allocation, Cassini managed to produce electricity from 600 to 700 watts. One of the Cassini reserve backup radiographs was used to force the New Horizons mission to Pluto and the Kuiper belt, designed and launched later.

To get a boost while flying, the Cassini mission trajectory includes several dust-engraved maneuvers: Two passes of Venus, another part of the Earth, then one of the planet Jupiter. The ground fly was the last case the probe puts any danger imaginable for human beings. The maneuver was successful and Cassini passed $1771 \mathrm{~km}$ above Earth on August 18, 1999. If there had been a failure that would cause the probe to collide with the Earth, the full NASA environmental impact study estimated that the worst case with a significant amount of $23 \mathrm{~kg}$ of plutonium gauze dispersed in the Earth's atmosphere, so up to five billion people in the country), 5,000 cancer deaths in the coming decades, $0.0005 \%$, representing a fraction of 0,000005 billion deaths in cancer; however, the chance of this happening was estimated at less than one million.

The Cassini space route was able to transmit in several different telemetry formats. The telemetry subsystem is probably the most important subsystem because without it there could be no data returns. 
Telemetry has been developed from the bottom because of the use of a more modern set of computers than previous missions. Cassini was, therefore, the first spacecraft to adopt mini-packages to reduce the complexity of the Telemetry Dictionary and the software development process led to the creation of a Telemetry Manager for the mission.

Approximately 1088 channels (in 67 mini-packages) were assembled in the Cassini Telemetry dictionary. Of the 67 mini-packages of reduced complexity, six minipackages containing the elements of the covariance subsystem and the Kalman gain (161 s) that were not used in normal mission missions. In 61 mini-packages, 947 measurements remain.

A total of seven telemetry maps corresponding to 7 AACS telemetry modes were built. These modes are: (1) Recording; (2) Cruise Nominal; (3) Cruise Medium Slow; (4) Slow Cruise; (5) Orbital Ops; (6) Av; (7) ATE Calibration (Attitude Estimator). These 7 maps cover all spacecraft telemetry modes.

The Huygens survey commissioned by the European Space Agency (ESA) and named after the 18th-century Dutch astronomer who first discovered that Titan Christiaan Huygens investigated the clouds, atmosphere and the surface of Titan Saturn on January 15, 2005, to interrupt and to stop the atmosphere Titan leaves a robot lab robot on the surface.

The probe system consisted of the probe itself that descended to Titan and the Probe Support (PSE), which remained attached to the orbital spacecraft. PSE includes probe electronics, recovers data collected during descent and processes and transmits data to Terra Blind. The base computer's CPU was a redundant MIL-STD-1750A control system.

The data was transmitted via a Huygens-Cassini radio link provided by the Relay Data Relay (PDR) subsystem. Since the probe's mission could not be commanded by Earth's telecommunication due to its long distance, it was automatically managed by the Data Command Management (CDMS) subsystem. PDRS and CDMS were provided by the Italian Space Agency (ASI).

After Cassini's launch, it was found that the data transmitted from the polls to the European Space Agency mission control center was largely difficult to read. It was found that Cassini's receiver failed to accurately process the frequency and wavelength changes of the signal he would have received from Huygens during his descent to Titan. The problem was corrected by changing the distance and the Cassini route to Huygens during the landing.

The Cassini field has made two roofs of gravity assistance from Venus on April 26, 1998 and June 24, 1999. The space ship provided sites with sufficient impulse to reach the asteroid belt. At that moment, the gravity of the Sun drew the space probe back into the inner solar system.
On August 18, 1999, at 03:28 UTC, the craft made a gravitational accompaniment of the Earth. With an hour and 20 minutes before approaching, Cassini approached the tone of the month at 377,000 kilometers and made a series of calibration photos.

On January 23, 2000, Cassini performed a flyby of the asteroid Mastersky 2685 at 10:00 UTC. He took pictures five to seven hours before the flight at a distance of 1.6 million kilometers and for the asteroid was estimated diameter of $15-20 \mathrm{~km}$.

Cassini made Jupiter's closest approach on December 30,2000 and made numerous scientific measurements. Approximately 26,000 images of Jupiter, its thin rings and the moon were taken over the six months. It produced the most comprehensive global color portrait in the world (see image on the right), where the smallest visible features are about $60 \mathrm{~km}(37 \mathrm{mi})$ above.

Cassini photographed Io crossing Jupiter on January 1, 2001 .

An important discovery of the plane announced on March 6, 2003, was Jupiter's atmospheric movement. Tents alternate dark areas of "light" in the atmosphere and scientists have long considered palm clouds in the surrounding air, partly because of the many clouds on Earth where the air is growing.

Other atmospheric observations included a dark, dark, high-fog oval, the magnitude of the Big Spot near the northern field of Jupiter. Infrared images have revealed aspects of motion near wind racks around the world, with adjacent bands moving in opposite directions.

The same announcement also discussed the nature of Jupiter's rings. The lack of light in the particles of rings has shown that the particles have an irregular shape (rather than spherical) and probably originate from the micrometeorite impact on the moons of Jupiter, perhaps Metis and Adrastea.

On October 10, 2003, the mission scientist announced the results of Albert Einstein's theory of general relativity, made using the radio waves transmitted by the Cassini space probe. Radio scientists measured a radio frequency shift to and from the space ship as it passes through the Sun. According to the general theory of relativity, a massive object, such as the Sun, produces space-time to curve, causing a beam of radio waves (or light or any form of electromagnetic radiation) passing through the Sun to shift to Shapiro's delay.

Although some deviations measured against the values calculated using the general theory of relativity are predicted by some unusual cosmological models, no deviations have been found in this experiment. Previous tests using the radio waves transmitted by Viking and Voyager probes were consistent with the values calculated from general relativity to a thousand accuracy. Several refined measurements from the Cassini probe have improved this accuracy to around 51,000. The data firmly support the general theory of Einstein's relativity. 
In total, the Cassini mission discovered seven new moons in Saturn's orbit. Using Cassini imagery, researchers discovered Methone, Pallene and Polydeuces in 2004, though later analysis showed that Voyager 2 photographed Pallene in 1981 when he flew the ringtone.

On May 1, 2005, Cassini discovered a new moon in Keeler Bay. It was called S/2005 S 1 before being named Daphnis. The fifth month was discovered by Cassini on May 30, 2007 and was provisionally named S/2007 S 4. It is now known as Anthe. A press release dated February 3, 2009, showed a new Cassini new month. The moon represents about $1 / 3$ of the diameter of the annular ring $G$ of Saturn's annular system and is now called Aegaeon (formerly S/2008 S 1). A press release dated November 2, 2009, mentions the seventh new month found by Cassini on July 26, 2009. It is currently labeled S/2009 S 1 and is about $300 \mathrm{~m}(1000 \mathrm{ft})$ in diameter in the B-ring system.

On April 14, 2014, NASA scientists reported the possibility of starting a new month in Saturn A.

On June 11, 2004, Cassini flew a month, Phoebe. This was the first opportunity for in-depth studies this month (Voyager 2 made a distant journey in 1981 but did not return detailed images). It was also possible for Cassini, for Phoebe, due to the orbital mechanics available around Saturn.

The first photos were received on June 12, 2004 and mission scientists immediately realized that the Phoebe surface was different from the asteroids visited by spacecraft. Parts of the very crafted surface look very bright in these images and it is believed that there is a large amount of water under its immediate surface.

In an announcement of June 28, 2004, Cassini scientists described the measurement of Saturn's rotation period. Since there are no fixed surface characteristics that can be used to achieve this period, the repetition of radio emissions has been used. These new data have agreed to the latest measured values on Earth and have been a puzzle for scientists. It seems that the rotation period of the radio has changed since it was first measured in 1980 by Voyager 1 and it was now 6 minutes longer. This, however, does not indicate a change in the global rotation of the planet. It is believed to be due to variations in the upper atmosphere and the ionosphere at latitudes that are magnetically connected to the radio source region.

On July 1, 2004, the spacecraft flew through the gap between the $F$ and $G$ rings and obtained orbit after a seven-year journey. It was Saturn's first spacecraft ever.

Cassini's Orbital Insertion (SOI) was complex, requiring the ship to route the High-Gain antenna away from Earth and along its flight path to protect the particles of Saturn's ring. Once the boat crossed the ring plane, it had to rotate again to straighten the engine along the flight path and then the engine began to detect the load with 622 meters/s to allow Saturn to capture it.
Cassini was captured by Saturn's gravity at 8:54 am Pacific on June 30, 2004. During the maneuver, Cassini crossed over $20,000 \mathrm{~km}$ of Saturn clouds.

When Cassini was in Saturn's orbit, the appreciation of the Saturn system was assessed in 2008 at the end of mission planning.

Cassini had the first flights of Titan on July 2, 2004, the day after the orbital insertion, when he approached Titan in the 339,000 kilometers. Images made by special filters (able to see through the fog of the moon) showed southern polar clouds considered methane and surface characteristics with a very different glow. On October 27, 2004, the spacecraft executed Titan's first planned flight, over 1,200 miles above the moon. Almost fourgigabit data were collected and transmitted to Earth, including the first radar images of the misty surface. He showed that the surface of the Titanium (at least the area covered by radar) is relatively level, the topography reaching a maximum of 50 meters in altitude. Coverage provided a remarkable increase in image resolution over previous coverage. Up to 100 times more resolutions were made and are typical of Titan flight plan resolutions. Cassini gathered the images of Titan and the methane lakes were similar to the lakes on Earth.

Cassini launched the Huygens probe on December 25,2004 , by means of arched and spiral tracks designed to rotate the probe for greater stability. He entered Titan's atmosphere on January 14, 2005 and after a twoand-a-half-hour descent, he landed on solid ground. Although Cassini managed to successfully pass the 350 images he received from Huygens on his landing and landing site, a software error failed to activate one of the Cassini receivers and caused the loss of another 350 images. During the landing, for caution, NASA loaded Huygens with 3 parachutes.

In the first two intersections of Enceladus in 2005, Cassini discovered a deviation of the local magnetic field that is characteristic of the existence of a thin but significant atmosphere. Other measurements obtained at that time in ionized water vapor as the main constituent. Cassini also noticed the ice geysers that broke out of the southern pole of Enceladus, which gives more credibility to the idea that Enceladus supplies the particles in the Saturn E ring. Scientists in the mission have begun to suspect that water pockets may appear liquids close to the surface of the month that feeds rash.

On March 12, 2008, Cassini moved to Enceladus, 50 $\mathrm{km}$ from the surface of the moon. Spatial vessels crossing the pits that extend from the southern geysers detect water, carbon dioxide and various hydrocarbons with the mass spectrometer, while surface characteristics are characterized by temperature much higher than the infrared spectrometer environment. Cassini failed to collect data with his cosmic dust analyzer due to an unknown software error.

On November 21, 2009, Cassini made the eighth trip from Enceladus, this time with a different geometry 
approaching 1,600 kilometers of surface. The Composite Infrared Spectrum (CIRS) produced the Bagdad Sulcus thermal emission map. The data obtained contributed to the creation of a detailed and high-resolution image of the Southern Moon, Saturn.

On April 3, 2014, nearly ten years after Cassini enters Saturn's orbit, NASA has proven to be a large and rich sea of liquid water in Enceladus. The presence of a salty inner ocean, in contact with the rocky core of the moon, places Enceladus "among the most probable places in the solar system to host a foreign microbial life." On June 30, 2014, NASA celebrated the 10-year exploration of Cassini, Saturn and its moons, highlighting the discovery of Enceladus's water activity among other discoveries.

In September 2015, NASA announced that Cassini gravity and imaging data were used to analyze the Enceladus perennial orbital plants and determined that the surface of the moon was not rigidly associated with its nucleus, concluding that the underground ocean must, therefore.

On October 28, 2015, Cassini approached Enceladus, coming in $49 \mathrm{~km}$ (30 mi) of surface and crossing the ice over the southern pole.

In May 2005, Cassini began a series of radio-occult experiments to measure the particle size distribution in Saturn's rings and measure Saturn's atmosphere. For four months, the boat was designed for this purpose. During these experiments, he flew the plane of Saturn's ring, as seen on Earth and transmitted radio waves through particles. Radio signals received on Terra were analyzed to change the frequency, phases and signal strength to determine the structure of the rings.

In the images captured on September 5, 2005, Cassini detected the Saturn rings (Fig. 6), previously observed only by Stephen James O'Meara's visual observer in 1977 and subsequently confirmed by Voyager spacecraft in the early 1980 s.

The radar images obtained on July 21, 2006, seem to show liquid hydrocarbon lakes (such as methane and ethane) in the northern latitudes of Titan. This is the first discovery of existing lakes anywhere on earth. Lakes vary from one to one hundred kilometers.

On March 13, 2007, the Jet Propulsion Laboratory announced that it found solid evidence of methane and ethane in Titan's northern hemisphere. At least one of these is larger than any of the Great Lakes in North America.

In November 2006, scientists discovered a storm at the southern pole of Saturn, with a distinct eyewall. This is characteristic of a hurricane on Earth and has never been seen on another planet. Unlike a terrestrial hurricane, the storm seems to be stationary at the pole. The storm has a height of 8,000 kilometers and a height of 70 kilometers (43 miles), with the wind blowing at 560 kilometers per hour (350 $\mathrm{mph}$ ).

On September 10, 2007, Cassini wrapped the walnutshaped Iapetus roof in two tones. The images were taken from $1,600 \mathrm{~km}$ above the surface. When he sent the images to Earth, he was hit by a cosmic ray that temporarily forced it. All flight data was recovered.

On April 15, 2008, Cassini received funding for an extended mission of 27 months. It consisted of 60 orbits of Saturn, with 21 planes near Titan, seven of Enceladus, six of Mimas, eight of Tethys and a destination in Dione, Rhea and Helene. The expanded mission began on July 1, 2008 and was renamed the Cassini Equinox mission, while the mission coincided with Saturn's equinox.

A proposal was submitted to NASA for a second extension of the mission (September 2010 - May 2017), provisionally referred to as the extended mission or XXM. This (\$ 60 million a year) was approved in February 2010 and was renamed the Cassini Solstice Mission. He included Cassini in Saturn's orbit several times, making 54 additional flights of Titan and 11 Enceladus.

On October 25, 2012, Cassini witnessed the massive storm from White, which is about 30 years old on Saturn. Data from the Infrared Spectrometer Composite Instrument (CIRS) indicated a strong storm discharge that caused a rise in the temperature of the Saturn $83 \mathrm{~K}$ $\left(83^{\circ} \mathrm{C}, 149^{\circ} \mathrm{F}\right)$ stratosphere compared to normal. At the same time, a huge increase in ethylene gas has been detected by NASA researchers at Goddard Research Center in Greenbelt, Maryland. Ethylene is a colorless gas that is extremely unusual on Saturn and is produced both naturally and by anthropogenic sources on Earth. The storm that caused this unloading was first observed by the spacecraft on December 5, 2010, in the northern hemisphere of Saturn. The storm is the first of its kind observed by a spacecraft in orbit around Saturn, as well as the first observed in infrared wavelengths, allowing scientists to observe the atmosphere of Saturn and observe the phenomena that are invisible to the naked eye. Condensation of ethylene gas produced by the storm has reached levels 100 times higher than those thought possible for Saturn. Scientists have also determined that the storm was the largest and most powerful stratospheric vortex ever detected in the solar system, initially being larger than Jupiter's Greate Red Spot.

On December 21, 2012, Cassini noticed a transit of Venus over the Sun. The VIMS instrument analyzed the sunlight passing through the Venusian atmosphere. VIMS previously noticed the transit of the exoplanet HD $189733 \mathrm{~b}$.

On July 19, 2013, the probe was directed to Earth to capture an image of the Earth and the Moon, as part of the natural light, of the multiple images of the entire Saturn system. The event was unique because it was the first time that NASA informed the public that a long distance photo was made in advance. The imaging team said he wanted people to smile and join the sky and Cassini researcher Carolyn Porco described time as a chance to "celebrate blue life." 


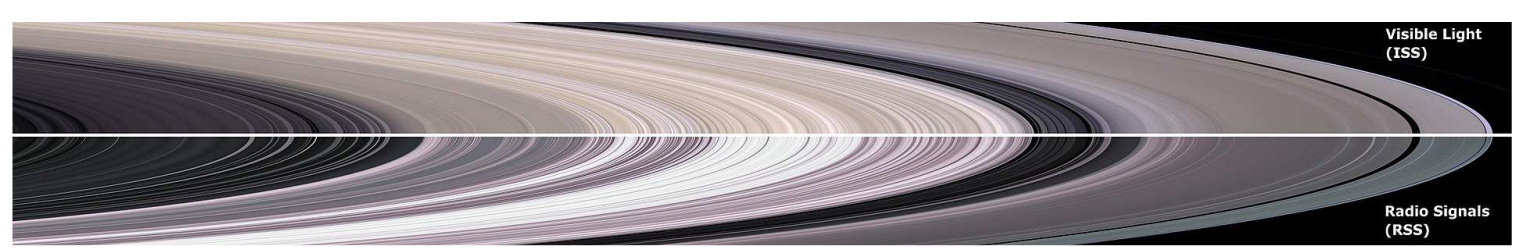

Fig. 6: The Saturn rings

Cassini last launched Hyperion on 31 May 2015, at a distance of about $34,000 \mathrm{~km}(21,000 \mathrm{mi})$.

Between 2012 and 2016, the persistent hexagonal cloud pattern at Saturn's northern pole changed from a blue color, especially in a golden color. A theory for this is a seasonal change: Exposure to sunlight can create opacity when the pole returns to the sun. It was previously noted that during 2004-2008 it was less white on Saturn.

Cassini's end involved a series of steps close to Saturn, approaching the rings, then entering Saturn's atmosphere on September 15, 2017, to destroy the space ship. This method has been chosen because it is imperative to ensure protection and to prevent biological contamination in any of the moons of Saturn considered to provide potential habitats.

In 2008, a number of options were assessed to achieve this objective, each with different funding, scientific and technical challenges. A brief impact on Saturn's impact at the end of the mission was rated "excellent" because "the D-Ring option meets AO targets that are unrealized, cheap and easy to access," while a frozen collision of the month was "time".

On November 29, 2016, the ship made a Titan flight that led to the orbital portion of the F ring: This was the beginning of the Grand Finale phase, culminating in its impact on the planet. An ultimate Titan flyby on April 22 , 2017, changed orbit again to fly through the gap between Saturn and his inner rings later on April 26. Cassini passed over $3100 \mathrm{~km}(1900 \mathrm{mi})$ above the Saturn cloud and $320 \mathrm{~km}$ ) the inner ring; successfully captured the images of Saturn's atmosphere and began to return the data the next day. After another 22 orbits, the mission ended with a dive in Saturn's atmosphere on September 15; the signal was lost at 7:55:46 AM EDT on September 15, 2017, just 30 seconds later than expected. It is estimated that the spacecraft burnt about 45 seconds after the last transmission.

In September 2018, NASA won an Emmy Award for an original interactive program for the Grand Final presentation of the Cassini Saturn mission.

In January 2019, new research was published using data collected during Cassini's Grand Finale phase:

Stopping the last round allows scientists to measure the duration of a day on Saturn: $10 \mathrm{~h}, 33 \mathrm{~min}$ and $38 \mathrm{sec}$.

Saturn's rings are relatively new, 10 to 100 million years old. Perhaps they were formed in the era of dinosaurs on Earth.
However, thanks to the increasing yields of solar cells, the last two spacecraft developed for the exploration of Jupiter - Juno and JUICE use solar panels which are however very large $\left(60 \mathrm{~m}^{2}\right.$ for Juno). These generators were also used on two machines launched to the surface of Mars - Viking 1 and 2 and the Curiosity rover because they make it possible to get away from the day/night cycle and are insensitive to the deposits of dust. The generators provide modest power: $100 \mathrm{~W}$ (45 $\mathrm{kg})$ for Curiosity, $300 \mathrm{~W}(\sim 56 \mathrm{~kg})$ for US space probes in service at the beginning of the 21 st century. To meet their electrical needs some probes ship up to three generators (Cassini, Voyager).

The space probe to fulfill its mission needs a propulsion system. This one can fulfill several roles which depend on the objectives of the mission and certain choices of the architecture of the space probe:

- Placed in orbit around the planet to be studied (orbiter)

- Course corrections

- Desaturation of the reaction wheels if the space probe uses this system to control its orientation

- Orientation control in the absence of reaction wheels

- Control of the velocity vector when the main propulsion is used

These different types of use require thrusters with very different characteristics (thrust, number of firings, duration). Also, the spacecraft usually has several types of thrusters to deal with these needs. In a relatively conventional way, a space probe comprises the main rocket engine with a thrust of several hundred Newtons for launching, clusters of small thrusters whose thrust ranges from a few tenths to a few $\mathrm{N}$. for orientation control and thrusters of a few dozen Newtons for trajectory or orbit corrections.

These are generally mono-ergol liquid propellant engines burning hydrazine or pergolas (usually hydrazine + hydrogen peroxide) which have the advantage of being storable for long periods of time and of being hypergolic (to burn spontaneously without firing device). These propellants are generally pressurized by helium itself stored in tanks under high pressure. Smaller cold gas thrusters (used to avoid pollution of instruments or collected samples, ionic engines (Deep Space 1 demonstrator, Dawn) are also 
more rarely found which require a suitable mission architecture and solid propellant engines (for insertion into orbit) used at the beginning of the space age (lunar landers of the Surveyor program).

The telecommunication system of a space probe is responsible for the exchange of data between it and the stations on Earth. These include in the sense spacecraftEarth periodically provided telemetry data that can monitor the status of the spacecraft and the data collected by the scientific instruments that materialize the results of the mission. In the direction, Earth-spacecraft passes the instructions given to the probe as well as any software updates. The characteristics of the telecommunication system depend on the distance between the space probe and the Earth, the amount of energy available, the mass of the probe. The most visible component of the system is the large gain satellite dish. The higher the diameter of this antenna, the more the radio beam emitted can be concentrated and the flow rate is high, which is vital when the distance to the Earth causes a sharp drop in the flow rate. The antenna can be fixed or steerable to allow it to point to the Earth independently of the orientation selected for the probe often constrained by the direction of the Sun (energy production) or with respect to the object under study (cameras).

For the radio link to work, the radio beam emitted by the large gain antenna must be pointed precisely towards the Earth. The spacecraft also has omnidirectional lowgain antennas that allow only a very low data rate but do not require pointing. These antennas are implemented at a short distance from the Earth but they allow above all to maintain the radio link in the event of failure of the pointing problem of the large gain antenna for example when the space probe can no longer maintain its orientation at following a failure of his computer or his attitude control system. There are also antennas with intermediate characteristics called gain means that emit a wide beam of 20 to $30^{\circ}$ with average flow rates. The radio transmitter transmits in $\mathrm{S}, \mathrm{X}$ or Ka-band.

The majority of scientific instruments aboard a spacecraft, especially aboard an orbiter, rely on the analysis of the electromagnetic radiation emitted by the objects observed. These instruments are, for example, cameras, spectrometers, radars. They exploit the fact that matter in all its states (gas, solid...) emits radiations which constitute a signature allowing to identify and to quantify its components (molecules or at fault type of atom). Indeed, space is permanently crossed by the electromagnetic radiation produced by celestial objects (stars, planets) but also resulting from past events (star explosion, Big Bang...). This radiation is more or less energetic (radio waves less energy to gamma rays through microwave radiation, infrared, visible light, ultraviolet and X-rays) depending on the phenomenon that gave birth. The material interacts with this radiation: Depending on the wavelength of the incident radiation it can absorb this radiation (absorption lines) or it can re-emit it with a stronger intensity in other wavelengths (emission lines). The phenomenon of fluorescence in which a material is struck by nonvisible radiation and re-emitted in the visible radiation is the most popularized case.

The instruments are classified into 4 main categories according to the observation method used:

\section{Remote sensing/Direct observation}

Remote sensing is the observation of an object at a distance. The cameras make it possible to obtain by this method an image of a distant object and a spectrometer measures the wavelengths of the radiation emitted by this object.

Direct, or in situ observation is the measurement of phenomena in contact with the instrument's sensors: A magnetometer measures the magnetic field in the immediate vicinity of the instrument and a dust detector measures the particles that strike its sensor directly.

\section{Passive/Active Instrument}

Instruments that make direct observations, such as those that use remote sensing, are either passive or active.

An active instrument uses energy to probe an object; this is, for example, the case of a radar which emits radio waves which are reflected by the studied object; these are then analyzed. This is also the case for the alpha particle X-ray spectrometer, which emits high-energy particles from a radioactive source. These last come to strike the object put in contact with it (a rock) and the instrument analyzes the X-rays returned by the object.

A passive instrument merely observes what is already there without providing energy to probe the object. This is the case of a camera unless a bright spot comes to illuminate the object (case of the camera onboard Huygens).

Some molecules, such as nitrogen or argon interact little with electromagnetic radiation. Heavy molecules, on the other hand, interact in a complex manner with emissions distributed over the entire spectral band, which makes their interpretation and the identification of the original molecule difficult. The mass spectrometer is an instrument used to identify and quantify molecules of this type. It is an instrument that is also well suited to cases where the density of molecules is low9. The mass spectrometer works in contact with the material used which limits its use to atmospheric probes and devices that land on the surface of the studied celestial objects (lander, rover). Its operation is based on the measurement of the mass of molecules. Different techniques can be used. After being ionized the material to be analyzed passes into a detector which can be a quadrupole analyzer, (analysis of the trajectory in a magnetic field) or a speed measuring system, etc. 


\section{Conclusion}

A space probe is a robotic spacecraft that does not orbit Earth, but instead, explores further into outer space. A space probe may approach the Moon; travel through interplanetary space; flyby, orbit, or land on other planetary bodies; or enter interstellar space.

The space agencies of the USSR (now Russia and Ukraine), the United States, the European Union, Japan, China, India and Israel have collectively launched probes to several planets and moons of the Solar System, as well as to a number of asteroids and comets. Approximately 15 missions are currently operational.

Once a probe has left the vicinity of Earth, its trajectory will likely take it along an orbit around the Sun similar to the Earth's orbit. To reach another planet, the simplest practical method is a Hohmann transfer orbit. More complex techniques, such as gravitational slingshots, can be more fuel-efficient, though they may require the probe to spend more time in transit. Some high Delta-V missions (such as those with high inclination changes) can only be performed, within the limits of modern propulsion, using gravitational slingshots. A technique using very little propulsion, but requiring a considerable amount of time, is to follow a trajectory on the Interplanetary Transport Network.

The Mars Exploration Rovers, Spirit and Opportunity landed on Mars to explore the Martian surface and geology and searched for clues to past water activity on Mars. They were each launched in 2003 and landed in 2004. Communication with Spirit stopped on Sol 2210 (March 22, 2010). JPL continued to attempt to regain contact until May 24, 2011, when NASA announced that efforts to communicate with the unresponsive rover had ended. Opportunity arrived at Endeavour crater on 9 August 2011, at a landmark called Spirit Point named after its rover twin, after traversing 13 miles $(21 \mathrm{~km})$ from Victoria crater, over a three-year period. After a planetwide dust storm in June 2018, the final communication was received on June 10, 2018 and Opportunity was declared dead on February 13, 2019. The rover lasted for almost fifteen years on Mars - although the rover was intended to last only three months.

The first dedicated missions to a comet; in this case, to Halley's Comet during its 1985-86 journey through the inner Solar System. It was also the first massive international coordination of space probes on an interplanetary mission, with probes specifically launched by the Soviet (now Russian) Space Agency, European Space Agency and Japan's ISAS (now integrated with NASDA to JAXA).

Originally a solar observatory in the International Sun-Earth Explorer series, it was sent into solar orbit to make the first close observations of a comet, Comet Giacobini-Zinner, in 1985 as a prelude to studies of Halley's Comet.
Vega, the Russian/French spacecraft. They dropped landers and balloons (first weather balloons deployed on another planet) at Venus before their rendezvous with Halley's Comet.

This Japanese probe, Sakigake, was the first non-US, non-Soviet interplanetary probe.

Giotto, the first space probe to penetrate a comet's coma and take close-up images of its nucleus.

Genesis was the first solar wind sample return probe from sun-earth L1.

Stardust was the first sample return probe from a comet tail.

NEAR Shoemaker was the first probe to land on an asteroid.

The Rosetta space probe flew by two asteroids and made a rendezvous and orbited comet $67 \mathrm{P} /$ ChuryumovGerasimenko in November 2014.

Pioneer 10 first probe to Jupiter. Radio communications were lost with Pioneer 10 on January 23,2003 , because of the loss of electric power for its radio transmitter, with the probe at a distance of 12 billion kilometers (80 AU) from Earth.

Pioneer 11 first probe to fly by Saturn. Communications were later lost due to power constraints and vast distance.

Voyager 1 is a 733-kilogram probe launched September 5, 1977. It visited Jupiter and Saturn and was the first probe to provide detailed images of the moons of these planets.

Voyager 1 is the farthest human-made object from Earth, traveling away from both the Earth and the Sun at a relatively faster speed than any other probe.

As of September 12, 2013, Voyager 1 is about 12 billion miles (19 billion kilometers) from the Sun.

Voyager 2 was launched by NASA on August 20, 1977.

The probe's primary mission was to visit the ice giants, Uranus, Cassini-Huygens was a 5,712 kg (12,593 lb) space probe designed to study gas giant Saturn, along with its ringed system and moons.

The NASA probe was launched with ESA lander Huygens on October 1, 1997, from Cape Canaveral. The Cassini probe entered Saturn orbit on July 1, 2004 and Huygens landed on Titan, Saturn's largest moon, on January 14, 2005.

On September 15, 2017, the probe was de-orbited and burned up in Saturn's atmosphere, after almost 20 years in space.

New Horizons first probe to be launched to Pluto. Launched on January 19, 2006, it flew by the PlutoCharon system on July 14, 2015.

Dawn was the first spacecraft to visit and orbit a protoplanet (4 Vesta), entering orbit on July 16, 2011.

Juno was the first probe to Jupiter without atomic batteries, launched August 8, 2011. 
Change 2 was deployed to orbit the Moon, visit SunEarth L2 Lagrangian point and make a flyby of asteroid 4179 Toutatis.

Along with Pioneer 10, Pioneer 11 and its sister space probe Voyager 2, Voyager 1 is now an interstellar probe.

Voyager 1 and 2 have both achieved solar escape velocity, meaning that their trajectories will not return them to the Solar System.

\section{Acknowledgement}

This text was acknowledged and appreciated by Dr. Veturia CHIROIU Honorific member of Technical Sciences Academy of Romania (ASTR) PhD supervisor in Mechanical Engineering.

\section{Funding Information}

Research contract: 1-Research contract: Contract number 36-5-4D/1986 from 24IV1985, beneficiary CNST RO (Romanian National Center for Science and Technology) Improving dynamic mechanisms.

2-Contract research integration. 19-91-3 from 29.03.1991; Beneficiary: MIS; TOPIC: Research on designing mechanisms with bars, cams and gears, with application in industrial robots.

3-Contract research. GR 69/10.05.2007: NURC in 2762; theme 8: Dynamic analysis of mechanisms and manipulators with bars and gears.

4-Labor contract, no. 35/22.01.2013, the UPB, "Stand for reading performance parameters of kinematics and dynamic mechanisms, using inductive and incremental encoders, to a Mitsubishi Mechatronic System" "PN-IIIN-CI-2012-1-0389".

All these matters are copyrighted! Copyrights: 394qodGnhhtej, from 17-02-2010 13:42:18; 463vpstuCGsiy, from 20-03-2010 12:45:30; 631sqfsgquutm, from 24-05-2010 16:15:22; 933CrDztEfqow, from 07-01-2011 13:37:52.

\section{Ethics}

This article is original and contains unpublished material. Authors declare that are not ethical issues and no conflict of interest that may arise after the publication of this manuscript.

\section{References}

Ab-Rahman, M.S., H. Guna, MH. Harun, SD. Zan and K. Jumari, 2009. Cost-effective fabrication of selfmade $1 \times 12$ polymer optical fiber-based optical splitters for automotive application. Am. J. Eng. Applied Sci., 2: 252-259.

DOI: 10.3844/ajeassp.2009.252.259
Abam, F.I., I.U. Ugot and D.I. Igbong, 2012. Performance analysis and components irreversibilities of a (25 $\mathrm{MW}$ ) gas turbine power plant modeled with a spray cooler. Am. J. Eng. Applied Sci., 5: 35-41.

DOI: 10.3844/ajeassp.2012.35.41

Abdelkrim, H., S.B. Othman, A.K.B. Salem and S.B. Saoud, 2012. Dynamic partial reconfiguration contribution on system on programmable chip architecture for motor drive implementation. Am. J. Eng. Applied Sci., 5: 15-24.

DOI: 10.3844/ajeassp.2012.15.24

Abdullah, M.Z., A. Saat and Z. Hamzah, 2011. Optimization of energy dispersive $\mathrm{X}$-ray fluorescence spectrometer to analyze heavy metals in moss samples. Am. J. Eng. Applied Sci., 4: 355362. DOI: 10.3844 /ajeassp.2011.355.362

Abdullah, M., A. F.M. Zain, Y. H. Ho and S. Abdullah, 2009. TEC and scintillation study of equatorial ionosphere: A month campaign over sipitang and parit raja stations, Malaysia. Am. J. Eng. Applied Sci., 2: 44-49. DOI: 10.3844/ajeassp.2009.44.49

Abdullah, H. and S.A. Halim, 2009. Electrical and magnetoresistive studies $\mathrm{Nd}$ doped on La-Ba-Mn- $\mathrm{O}_{3}$ manganites for low-field sensor application. Am. J. Eng. Applied Sci., 2: 297-303.

DOI: 10.3844/ajeassp.2009.297.303

Abouobaida, H., 2016. Robust and efficient controller to design a standalone source supplied DC and AC load powered by photovoltaic generator. Am. J. Eng. Applied Sci., 9: 894-901.

DOI: 10.3844 /ajeassp.2016.894.901

Abu-Ein, S., 2009. Numerical and analytical study of exhaust gases flow in porous media with applications to diesel particulate filters. Am. J. Eng. Applied Sci., 2: 70-75.

DOI: 10.3844 /ajeassp.2009.70.75

Abu-Lebdeh, M., G. Pérez-de León, S.A. Hamoush, R.D. Seals and V.E. Lamberti, 2016. Gas atomization of molten metal: Part II. Applications. Am. J. Eng. Applied Sci., 9: 334-349. DOI: 10.3844/ajeassp.2016.334.349

Agarwala, S., 2016. A perspective on 3D bioprinting technology: Present and future. Am. J. Eng. Applied Sci., 9: 985-990.

DOI: 10.3844 ajeassp.2016.985.990

Ahmed, M., R. Khan, M. Billah and S. Farhana, 2010. A novel navigation algorithm for hexagonal hexapod robot. Am. J. Eng. Applied Sci., 3: 320-327. DOI: 10.3844 /ajeassp.2010.320.327

Ahmed, M.K., H. Haque and H. Rahman, 2016. An approach to develop a dynamic job shop scheduling by fuzzy rule-based system and comparative study with the traditional priority rules. Am. J. Eng. Applied Sci., 9: 202-212.

DOI: 10.3844/ajeassp.2016.202.212 
Akhesmeh, S., N. Pourmahmoud and H. Sedgi, 2008. Numerical study of the temperature separation in the ranque-hilsch vortex tube. Am. J. Eng. Applied Sci., 1: 181-187. DOI: 10.3844/ajeassp.2008.181.187

Akubue, A., 2011. Appropriate technology for socioeconomic development in third world countries. J. Technol. Stud., 26: 33-43.

DOI: $10.21061 /$ jots.v26il.a.6

Al-Abbas, I.K., 2009. Reduced order models of a current source inverter induction motor drive. Am. J. Eng. Applied Sci., 2: 39-43.

DOI: 10.3844/ajeassp.2009.39.43

Al-Hasan and A.S. Al-Ghamdi, 2016. Energy balance for a diesel engine operates on a pure biodiesel, diesel fuel and biodiesel-diesel blends. Am. J. Eng. Applied Sci., 9: 458-465.

DOI: 10.3844/ajeassp.2016.458.465

Al Smadi, T.A., 2011. Low cost smart sensor design. Am. J. Eng. Applied Sci., 4: 162-168. DOI: 10.3844/ajeassp.2011.162.168

Al Qadi, A.N.S., M.B.A. ALhasanat, A. AL Dahamsheh and S. AL Zaiydneen, 2016a. Using of box-benken method to predict the compressive strength of selfcompacting concrete containing Wadi Musa bentonite, Jordan. Am. J. Eng. Applied Sci., 9: 406411. DOI: 10.3844/ajeassp.2016.406.411

Al Qadi, A.N.S., M.B.A. Alhasanat and M. Haddad, 2016b. Effect of crumb rubber as coarse and fine aggregates on the properties of asphalt concrete. Am. J. Eng. Applied Sci., 9: 558-564.

DOI: 10.3844/ajeassp.2016.558.564

Aleksic, S. and A. Lovric, 2011. Energy consumption and environmental implications of wired access networks. Am. J. Eng. Applied Sci., 4: 531-539. DOI: 10.3844/ajeassp.2011.531.539

Alhasanat, M.B., A.N. Al Qadi, O.A. Al Khashman and A. Dahamsheh, 2016. Scanning electron microscopic evaluation of self-compacting concrete spalling at elevated temperatures. Am. J. Eng. Applied Sci., 9: 119-127.

DOI: 10.3844/ajeassp.2016.119.127

Ali, K.S. and JL. Shumaker, 2013. Hardware in the loop simulator for multi-agent unmanned aerial vehicles environment. Am. J. Eng. Applied Sci., 6: 172-177. DOI: 10.3844/ajeassp.2013.172.177

Ali, G.A.M., O. Fouad and S.A. Makhlouf, 2016. Electrical properties of cobalt oxide/silica nanocomposites obtained by sol-gel technique. Am. J. Eng. Applied Sci., 9: 12-16.

DOI: 10.3844/ajeassp.2016.12.16

Al-Nasra, M. Daoudb and T.M. Abu-Lebdeh, 2015. The use of the super absorbent polymer as water blocker in concrete structures. Am. J. Eng. Applied Sci., 8: 659-665. DOI: 10.3844/ajeassp.2015.659.665
Alwetaishi, M.S., 2016. Impact of building function on thermal comfort: A review paper. Am. J. Eng. Applied Sci., 9: 928-945.

DOI: 10.3844/ajeassp.2016.928.945

Aly, W.M. and M.S. Abuelnasr, 2010. Electronic design automation using object oriented electronics. Am. J. Eng. Applied Sci., 3: 121-127. DOI: 10.3844 /ajeassp.2010.121.127

Amani, N., 2016. Design and implementation of optimum management system using cost evaluation and financial analysis for prevention of building failure. Am. J. Eng. Applied Sci., 9: 281-296. DOI: 10.3844/ajeassp.2016.281.296

Amer, S., S. Hamoush and T.M. Abu-Lebdeh, 2015. Experimental evaluation of the raking energy in damping system of steel stud partition walls. Am. J. Eng. Applied Sci., 8: 666-677.

DOI: 10.3844/ajeassp.2015.666.677

Anizan, S., K. Yusri, C.S. Leong, N. Amin and S. Zaidi et al., 2011. Effects of the contact resistivity variations of the screen-printed silicon solar cell. Am. J. Eng. Applied Sci., 4: 328-331. DOI: 10.3844 /ajeassp.2011.328.331

Angeles, J. and C. Lopez-Cajun, 1988. Optimal synthesis of cam mechanisms with oscillating flat-face followers. Mechanism Mach. Theory, 23: 1-6. DOI: $10.1016 / 0094-114 X(88) 90002-X$

Antonescu, P., 2000. Mechanisms and Handlers. 1st Edn., Printech Publishing House, Bucharest.

Antonescu, P. and F.I.T. Petrescu, 1985. An analytical method of synthesis of cam mechanism and flat stick. Proceedings of the 4th International Symposium on Theory and Practice of Mechanisms, (TPM' 85), Bucharest.

Antonescu, P. and F.I.T. Petrescu, 1989. Contributions to cinetoelastodynamic analysis of distribution mechanisms. Bucharest.

Antonescu, P., M. Oprean and F.I.T. Petrescu, 1985a. Contributions to the synthesis of oscillating cam mechanism and oscillating flat stick. Proceedings of the 4th International Symposium on Theory and Practice of Mechanisms, (TPM' 85), Bucharest.

Antonescu, P., M. Oprean and F.I.T. Petrescu, 1985b. At the projection of the oscillate cams, there are mechanisms and distribution variables. Proceedings of the 5th Conference of Engines, Automobiles, Tractors and Agricultural Machines, (AMA' 58), IMotors and Cars, Brasov.

Antonescu, P., M. Oprean and F.I.T. Petrescu, 1986. Projection of the profile of the rotating camshaft acting on the oscillating plate with disengagement. Proceedings of the 3rd National Computer-aided Design Symposium in the field of Mechanisms and Machine Parts, (MMP' 86), Brasov. 
Antonescu, P., M. Oprean and F.I.T. Petrescu, 1987. Dynamic analysis of the cam distribution mechanisms. Proceedings of the 7 th National Symposium on Industrial Robots and Space Mechanisms, (RSM' 87), Bucharest.

Antonescu, P., M. Oprean and F.I.T. Petrescu, 1988. Analytical synthesis of Kurz profile, rotating the flat cam. Mach, Build. Rev.

Antonescu, P., F.I.T. Petrescu and O. Antonescu, 1994. Contributions to the synthesis of the rotating cam mechanism and the tip of the balancing tip. Brasov.

Antonescu, P., F.I.T. Petrescu and D. Antonescu, 1997. Geometrical synthesis of the rotary cam and balance tappet mechanism. Bucharest, 3: 23-23.

Antonescu, P., F.I.T. Petrescu and O. Antonescu, 2000a. Contributions to the synthesis of the rotary disc-cam profile. Proceedings of the 8th International Conference on the Theory of Machines and Mechanisms, (TMM' 00), Liberec, Czech Republic, pp: 51-56.

Antonescu, P., F.I.T. Petrescu and O. Antonescu, 2000b. Synthesis of the rotary cam profile with balance follower. Proceedings of the 8th Symposium on Mechanisms and Mechanical Transmissions, (MMT'00), Timişoara, pp: 39-44.

Antonescu, P., F. Petrescu and O. Antonescu, 2001. Contributions to the synthesis of mechanisms with rotary disc-cam. Proceedings of the 8th IFToMM International Symposium on Theory of Machines and Mechanisms, (TMM' 01), Bucharest, ROMANIA, pp: 31-36.

Ascione, F., N. Bianco, R.F. De Masi, F. de Rossi and C. De Stasio et al., 2016. Energy audit of health care facilities: dynamic simulation of energy performances and energy-oriented refurbishment of system and equipment for microclimatic control. Am. J. Eng. Applied Sci., 9: 814-834.

DOI: 10.3844/ajeassp.2016.814.834

Augustine, A., R.D. Prakash, R. Xavier and M.C. Parassery, 2016. Review of signal processing techniques for detection of power quality events. Am. J. Eng. Applied Sci., 9: 364-370. DOI: 10.3844/ajeassp.2016.364.370

Aversa, R., R.V.V. Petrescu, A. Apicella and F.I.T. Petrescu, 2017a. Nano-diamond hybrid materials for structural biomedical application. Am. J. Biochem. Biotechnol., 13: 34-41. DOI: 10.3844/ajbbsp.2017.34.41

Aversa, R., R.V. Petrescu, B. Akash, R.B. Bucinell and J.M. Corchado et al., 2017b. Kinematics and forces to a new model forging manipulator. Am. J. Applied Sci., 14: 60-80. DOI: 10.3844/ajassp.2017.60.80

Aversa, R., R.V. Petrescu, A. Apicella, F.I.T. Petrescu and J.K. Calautit et al., 2017c. Something about the $\mathrm{V}$ engines design. Am. J. Applied Sci., 14: 34-52. DOI: 10.3844 /ajassp.2017.34.52
Aversa, R., D. Parcesepe, R.V.V. Petrescu, F. Berto and G. Chen et al., 2017d. Process ability of bulk metallic glasses. Am. J. Applied Sci., 14: 294-301. DOI: 10.3844/ajassp.2017.294.301

Aversa, R., R.V.V. Petrescu, B. Akash, R.B. Bucinell and J.M. Corchado et al., 2017e. Something about the balancing of thermal motors. Am. J. Eng. Applied Sci., 10: 200.217. DOI: 10.3844/ajeassp.2017.200.217

Aversa, R., F.I.T. Petrescu, R.V. Petrescu and A. Apicella, 2016a. Biomimetic FEA bone modeling for customized hybrid biological prostheses development. Am. J. Applied Sci., 13: 1060-1067. DOI: 10.3844/ajassp.2016.1060.1067

Aversa, R., D. Parcesepe, R.V. Petrescu, G. Chen and F.I.T. Petrescu et al., 2016b. Glassy amorphous metal injection molded induced morphological defects. Am. J. Applied Sci., 13: 1476-1482. DOI: 10.3844 /ajassp.2016.1476.1482

Aversa, R., R.V. Petrescu, F.I.T. Petrescu and A. Apicella, 2016c. Smart-factory: Optimization and process control of composite centrifuged pipes. Am. J. Applied Sci., 13: 1330-1341.

DOI: 10.3844/ajassp.2016.1330.1341

Aversa, R., F. Tamburrino, R.V. Petrescu, F.I.T. Petrescu and M. Artur et al., 2016d. Biomechanically inspired shape memory effect machines driven by muscle like acting NiTi alloys. Am. J. Applied Sci., 13: 1264-1271. DOI: 10.3844/ajassp.2016.1264.1271

Aversa, R., E.M. Buzea, R.V. Petrescu, A. Apicella and M. Neacsa et al., 2016e. Present a mechatronic system having able to determine the concentration of carotenoids. Am. J. Eng. Applied Sci., 9: 11061111. DOI: 10.3844/ajeassp.2016.1106.1111

Aversa, R., R.V. Petrescu, R. Sorrentino, F.I.T. Petrescu and A. Apicella, 2016f. Hybrid ceramo-polymeric nanocomposite for biomimetic scaffolds design and preparation. Am. J. Eng. Applied Sci., 9: 1096-1105. DOI: 10.3844/ajeassp.2016.1096.1105

Aversa, R., V. Perrotta, R.V. Petrescu, C. Misiano and F.I.T. Petrescu et al., 2016g. From structural colors to super-hydrophobicity and achromatic transparent protective coatings: Ion plating plasma assisted $\mathrm{TiO}_{2}$ and $\mathrm{SiO}_{2}$ nano-film deposition. Am. J. Eng. Applied Sci., 9: 1037-1045.

DOI: 10.3844/ajeassp.2016.1037.1045

Aversa, R., R.V. Petrescu, F.I.T. Petrescu and A. Apicella, 2016h. Biomimetic and evolutionary design driven innovation in sustainable products development. Am. J. Eng. Applied Sci., 9: $1027-$ 1036. DOI: 10.3844 /ajeassp.2016.1027.1036

Aversa, R., R.V. Petrescu, A. Apicella and F.I.T. Petrescu, 2016i. Mitochondria are naturally micro robots - a review. Am. J. Eng. Applied Sci., 9: 9911002. DOI: 10.3844/ajeassp.2016.991.1002 
Aversa, R., R.V. Petrescu, A. Apicella and F.I.T. Petrescu, 2016j. We are addicted to vitamins $\mathrm{C}$ and E-A review. Am. J. Eng. Applied Sci., 9: 10031018. DOI: 10.3844 /ajeassp.2016.1003.1018

Aversa, R., R.V. Petrescu, A. Apicella and F.I.T. Petrescu, 2016k. Physiologic human fluids and swelling behavior of hydrophilic biocompatible hybrid ceramo-polymeric materials. Am. J. Eng. Applied Sci., 9: 962-972.

DOI: 10.3844 /ajeassp.2016.962.972

Aversa, R., R.V. Petrescu, A. Apicella and F.I.T. Petrescu, 2016l. One can slow down the aging through antioxidants. Am. J. Eng. Applied Sci., 9: 1112-1126. DOI: 10.3844/ajeassp.2016.1112.1126

Aversa, R., R.V. Petrescu, A. Apicella and F.I.T. Petrescu, 2016m. About homeopathy or «Similia Similibus Curentur 》. Am. J. Eng. Applied Sci., 9: 1164-1172. DOI: 10.3844/ajeassp.2016.1164.1172

Aversa, R., R.V. Petrescu, A. Apicella and F.I.T. Petrescu, 2016n. The basic elements of life's. Am. J. Eng. Applied Sci., 9: 1189-1197. DOI: 10.3844/ajeassp.2016.1189.1197

Aversa, R., F.I.T. Petrescu, R.V. Petrescu and A. Apicella, 2016o. Flexible stem trabecular prostheses. Am. J. Eng. Applied Sci., 9: 1213-1221. DOI: 10.3844/ajeassp.2016.1213.122

Babayemi, A.K., 2016. Thermodynamics, non-linear isotherms, statistical modeling and optimization of phosphorus adsorption from wastewater. Am. J. Eng. Applied Sci., 9: 1019-1026. DOI: 10.3844/ajeassp.2016.1019.1026

Bakar, R.A., M.K. Mohammed and M.M. Rahman, 2009. Numerical study on the performance characteristics of hydrogen fueled port injection internal combustion engine. Am. J. Eng. Applied Sci., 2: 407-415.

DOI: $10.3844 /$ ajeassp.2009.407.415

Barone, G., A. Buonomano, C. Forzano and A. Palombo, 2016. WLHP systems in commercial buildings: A case study analysis based on a dynamic simulation approach. Am. J. Eng. Applied Sci., 9: 659-668. DOI: 10.3844/ajeassp.2016.659.668

Bedon, C., 2016. Review on the use of FRP composites for facades and building skins. Am. J. Eng. Applied Sci., 9: 713-723.

DOI: 10.3844 /ajeassp.2016.713.723

Bedon, C. and C. Amadio, 2016. A unified approach for the shear buckling design of structural glass walls with non-ideal restraints. Am. J. Eng. Applied Sci., 9: 64-78. DOI: 10.3844/ajeassp.2016.64.78

Bedon, C. and C. Louter, 2016. Finite-element numerical simulation of the bending performance of posttensioned structural glass beams with adhesively bonded CFRP tendons. Am. J. Eng. Applied Sci., 9: 680-691. DOI: 10.3844/ajeassp.2016.680.691
Bier, H. and S. Mostafavi, 2015. Structural optimization for materially informed design to robotic production processes. Am. J. Eng. Applied Sci., 8: 549-555. DOI: 10.3844/ajeassp.2015.549.555

Bolonkin, A., 2009a. Femtotechnology: Nuclear matter with fantastic properties. Am. J. Eng. Applied Sci., 2: 501-514. DOI: 10.3844/ajeassp.2009.501.514

Bolonkin, A., 2009b. Converting of matter to nuclear energy by ab-generator. Am. J. Eng. Applied Sci., 2: 683-693. DOI: 10.3844/ajeassp.2009.683.693

Boucetta, A., 2008. Vector control of a variable reluctance machine stator and rotor discs imbricates. Am. J. Eng. Applied Sci., 1: 260-265. DOI: 10.3844 /ajeassp.2008.260.265

Bourahla, N. and A. Blakeborough, 2015. Similitude distortion compensation for a small scale model of a knee braced steel frame. Am. J. Eng. Applied Sci., 8: 481-488. DOI: 10.3844/ajeassp.2015.481.488

Bucinell, R.B., 2016. Stochastic model for variable amplitude fatigue induced delamination growth in graphite/epoxy laminates. Am. J. Eng. Applied Sci., 9: 635-646. DOI: 10.3844/ajeassp.2016.635.646

Budak, S., Z. Xiao, B. Johnson, J. Cole and M. Drabo et al., 2016. Highly-efficient advanced thermoelectric devices from different multilayer thin films. Am. J. Eng. Applied Sci., 9: 356-363.

DOI: 10.3844/ajeassp.2016.356.363

Buonomano, A., F. Calise and M. Vicidomini, 2016a. A novel prototype of a small-scale solar power plant: Dynamic simulation and thermoeconomic analysis. Am. J. Eng. Applied Sci., 9: 770-788. DOI: 10.3844 /ajeassp.2016.770.788

Buonomano, A., F. Calise, M.D. d'Accadia, R. Vanoli and M. Vicidomini, 2016b. Simulation and experimental analysis of a demonstrative solar heating and cooling plant installed in Naples (Italy). Am. J. Eng. Applied Sci., 9: 798-813. DOI: 10.3844 /ajeassp.2016.798.813

Cao, W., H. Ding, Z. Bin and C. Ziming, 2013. New structural representation and digital-analysis platform for symmetrical parallel mechanisms. Int. J. Adv. Robotic Sys. DOI: 10.5772/56380

Calise, F., M.D. dâ' Accadia, L. Libertini, E. Quiriti and M. Vicidomini, 2016b. Dynamic simulation and optimum operation strategy of a trigeneration system serving a hospital. Am. J. Eng. Applied Sci., 9: 854-867. DOI: 10.3844/ajeassp.2016.854.867

Campo, T., M. Cotto, F. Marquez, E. Elizalde and C. Morant, 2016. Graphene synthesis by plasmaenhanced CVD growth with ethanol. Am. J. Eng. Applied Sci., 9: 574-583. DOI: 10.3844 /ajeassp.2016.574.583

Cardu, M., P. Oreste and T. Cicala, 2009. Analysis of the tunnel boring machine advancement on the BolognaFlorence railway link. Am. J. Eng. Applied Sci., 2: 416-420. DOI: 10.3844/ajeassp.2009.416.420 
Casadei, D., 2015. Bayesian statistical inference for number counting experiments. Am. J. Eng. Applied Sci., 8: 730-735.

DOI: 10.3844 ajeassp.2015.730.735

Cataldo, R., 2006. Overview of planetary power system options for education. ITEA Human Exploration Project Authors, Glenn Research Center. Brooke Park, $\mathrm{OH}$.

Chang, S.P., M.C. Chen and J.D. Lin, 2015. Study of heat-treated steel and related applications. Am. J. Eng. Applied Sci., 8: 611-619.

DOI: 10.3844/ajeassp.2015.611.619

Chen, G. and L. Xu, 2016. A general strategy to enhance up conversion luminescence in rare-earth-ion-doped oxide nanocrystals. Am. J. Eng. Applied Sci., 9: 7983. DOI: 10.3844 /ajeassp.2016.79.83

Chiozzi, A., G. Milani, N. Grillanda and A. Tralli, 2016. An adaptive procedure for the limit analysis of FRP reinforced masonry vaults and applications. Am. J. Eng. Applied Sci., 9: 735-745.

DOI: 10.3844/ajeassp.2016.735.745

Chisari, C. and C. Bedon, 2016. Multi-objective optimization of FRP jackets for improving the seismic response of reinforced concrete frames. Am. J. Eng. Applied Sci., 9: 669-679. DOI: 10.3844/ajeassp.2016.669.679

Comanescu, A., 2010. Bazele Modelarii Mecanismelor. 1st Edn., E. Politeh, Press, Bucureşti, pp: 274.

Darabi, A., S.A. Soleamani and A. Hassannia, 2008. Fuzzy based digital automatic voltage regulator of a synchronous generator with unbalanced loads. Am. J. Eng. Applied Sci., 1: 280-286. DOI: 10.3844/ajeassp.2008.280.286

Daud, H., N. Yahya, A.A. Aziz and M.F. Jusoh, 2008. Development of wireless electric concept powering electrical appliances. Am. J. Eng. Applied Sci., 1: 12-15. DOI: 10.3844/ajeassp.2008.12.15

Demetriou, D., N. Nikitas and K.D. Tsavdaridis, 2015. Semi active tuned mass dampers of buildings: A simple control option. Am. J. Eng. Applied Sci., 8: 620-632. DOI: 10.3844/ajeassp.2015.620.632

Dixit, S. and S. Pal, 2015. Synthesis and characterization of ink (Carbon)-perovskite/polyaniline ternary composite electrode for sodium chloride separation.

Am. J. Eng. Applied Sci., 8: 527-537. DOI: 10.3844/ajeassp.2015.527.537

Djalel, D., M. Mourad and H. Labar, 2013. New approach of electromagnetic fields of the lightning discharge. Am. J. Eng. Applied Sci., 6: 369-383. DOI: 10.3844/ajeassp.2013.369.383

Dong, H., N. Giakoumidis, N. Figueroa and N. Mavridis, 2013. Approaching behaviour monitor and vibration indication in developing a General Moving Object Alarm System (GMOAS). Int. J. Adv. Robotic Sys. DOI: $10.5772 / 56586$
Ebrahim, N.A., S. Ahmed, S.H.A. Rashid and Z. Taha, 2012. Technology use in the virtual R\&D teams. Am. J. Eng. Applied Sci., 5: 9-14. DOI: 10.3844/ajeassp.2012.9.14

El-Labban, H.F., M. Abdelaziz and E.R.I. Mahmoud, 2013. Modification of carbon steel by laser surface melting: Part I: Effect of laser beam travelling speed on microstructural features and surface hardness. Am. J. Eng. Applied Sci., 6: 352-359. DOI: 10.3844 /ajeassp.2013.352.359

Elliott, A., S. AlSalihi, A.L. Merriman and M.M. Basti, 2016. Infiltration of nanoparticles into porous binder jet printed parts. Am. J. Eng. Applied Sci., 9: 128133. DOI: 10.3844/ajeassp.2016.128.133

Elmeddahi, Y., H. Mahmoudi, A. Issaadi, M.F.A. Goosen and R. Ragab, 2016b. Evaluating the effects of climate change and variability on water resources: A case study of the cheliff Basin in Algeria. Am. J. Eng. Applied Sci., 9: 835-845. DOI: 10.3844 /ajeassp.2016.835.845

El-Tous, Y., 2008. Pitch angle control of variable speed wind turbine. Am. J. Eng. Applied Sci., 1: 118-120. DOI: 10.3844 /ajeassp.2008.118.120

Faizal, A., S. Mulyono, R. Yendra and A. Fudholi, 2016. Design Maximum Power Point Tracking (MPPT) on photovoltaic panels using fuzzy logic method. Am. J. Eng. Applied Sci., 9: 789-797. DOI: 10.3844/ajeassp.2016.789.797

Farahani, A.S., N.M. Adam and M.K.A. Ariffin, 2010. Simulation of airflow and aerodynamic forces acting on a rotating turbine ventilator. Am. J. Eng. Applied Sci., 3: 159-170. DOI: 10.3844/ajeassp.2010.159.170

Farokhi, E. and M. Gordini, 2015. Investigating the parameters influencing the behavior of knee braced steel structures. Am. J. Eng. Applied Sci., 8: 567574. DOI: 10.3844/ajeassp.2015.567.574

Fathallah, A.Z.M. and R.A. Bakar, 2009. Prediction studies for the performance of a single cylinder high speed spark ignition linier engine with spring mechanism as return cycle. Am. J. Eng. Applied Sci., 2: 713-720. DOI: 10.3844/ajeassp.2009.713.720

Fawcett, G.F. and J.N. Fawcett, 1974. Comparison of Polydyne and Non Polydyne Cams. In: Cams and Cam Mechanisms, Rees Jones, J. (Ed.), MEP, London and Birmingham, Alabama.

Fen, Y.W., W.M.M. Yunus, M.M. Moksin, Z.A. Talib and N.A. Yusof, 2011. Optical properties of crosslinked chitosan thin film with glutaraldehyde using surface Plasmon resonance technique. Am. J. Eng. Applied Sci., 4: 61-65. DOI: 10.3844/ajeassp.2011.61.65

Feraga, C.E., A. Moussaoui, A. Bouldjedri and A. Yousfi, 2009. Robust position controller for a permanent magnet synchronous actuator. Am. J. Eng. Applied Sci., 2: 388-392.

DOI: $10.3844 /$ ajeassp.2009.388.392 
Franklin, D.J., 1930. Ingenious Mechanisms for Designers and Inventors. 1st Edn., Industrial Press Publisher.

Fu, Y.F., J. Gong, H. Huang, Y.J. Liu and D. Zhu et al., 2015. Parameters optimization of adaptive cashew shelling cutter based on BP neural network and genetic algorithm. Am. J. Eng. Applied Sci., 8: 648658. DOI: 10.3844/ajeassp.2015.648.658

Gao, F., W.Z. Guo, Q.Y. Song and F.S. Du, 2010. Current development of heavy-duty manufacturing equipment. J. Mech. Eng., 46: 92-107.

Ge, H. and F. Gao, 2012. Type design for heavy-payload forging manipulators. Chinese J. Mech. Eng., 25: 197-205.

Ge, L. and X. Xu, 2015. A scheme design of cloud + end technology in demand side management. Am. J. Eng. Applied Sci., 8: 736-747. DOI: 10.3844/ajeassp.2015.736.747

Giordana, F., V. Rognoni and G. Ruggieri, 1979. On the influence of measurement errors in the Kinematic analysis of cam. Mechanism Mach. Theory, 14: 327340. DOI: 10.1016/0094-114X(79)90019-3

Gruener, J.E., 2006. Lunar exploration (Presentation to ITEA Human Exploration Project Authors, November 2006, at Johnson Space Center). Houston, TX.

Gupta, P., A. Gupta and A. Asati, 2015. Ultra low power MUX based compressors for Wallace and Dadda multipliers in sub-threshold regime. Am. J. Eng. Applied Sci., 8: 702-716. DOI: 10.3844 /ajeassp.2015.702.716

Gusti, A.P. and Semin, 2016. The effect of vessel speed on fuel consumption and exhaust gas emissions. Am. J. Eng. Applied Sci., 9: 1046-1053. DOI: 10.3844/ajeassp.2016.1046.1053

Hain, K., 1971. Optimization of a cam mechanism to give good transmissibility maximal output angle of swing and minimal acceleration. J. Mechanisms, 6: 419-434. DOI: 10.1016/0022-2569(71)90044-9

Hassan, M., H. Mahjoub and M. Obed, 2012. Voicebased control of a DC servo motor. Am. J. Eng. Applied Sci., 5: 89-92.

DOI: 10.3844/ajeassp.2012.89.92

Hasan, S. and M.H. El-Naas, 2016. Optimization of a combined approach for the treatment of carbide slurry and capture of $\mathrm{CO}_{2}$. Am. J. Eng. Applied Sci., 9: 449-457. DOI: 10.3844/ajeassp.2016.449.457

Helmy, A.K. and G.S. El-Taweel, 2010. Neural network change detection model for satellite images using textural and spectral characteristics. Am. J. Eng. Applied Sci., 3: 604-610. DOI: 10.3844 /ajeassp.2010.604.610

Hirun, W., 2016. Evaluation of interregional freight generation modelling methods by using nationwide commodity flow survey data. Am. J. Eng. Applied Sci., 9: 625-634.

DOI: 10.3844/ajeassp.2016.625.634
Ho, C.Y.F., B.W.K. Ling, S.G. Blasi, Z.W. Chi and W.C. Siu, 2011. Single step optimal block matched motion estimation with motion vectors having arbitrary pixel precisions. Am. J. Eng. Applied Sci., 4: 448-460. DOI: 10.3844/ajeassp.2011.448.460

Huang, B., S.H. Masood, M. Nikzad, P.R. Venugopal and A. Arivazhagan, 2016. Dynamic mechanical properties of fused deposition modelling processed polyphenylsulfone material. Am. J. Eng. Applied Sci., 9: 1-11. DOI: 10.3844/ajeassp.2016.1.11

He, B., Z. Wang, Q. Li, H. Xie and R. Shen, 2013. An analytic method for the kinematics and dynamics of a multiple-backbone continuum robot. IJARS. DOI: $10.5772 / 54051$

Idarwazeh, S., 2011. Inverse discrete Fourier transformdiscrete Fourier transform techniques for generating and receiving spectrally efficient frequency division multiplexing signals. Am. J. Eng. Applied Sci., 4: 598-606. DOI: 10.3844/ajeassp.2011.598.606

Iqbal, 2016. An overview of Energy Loss Reduction (ELR) software used in Pakistan by WAPDA for calculating transformer overloading, line losses and energy losses. Am. J. Eng. Applied Sci., 9: 442-448. DOI: 10.3844/ajeassp.2016.442.448

Ismail, M.I.S., Y. Okamoto, A. Okada and Y. Uno, 2011. Experimental investigation on micro-welding of thin stainless steel sheet by fiber laser. Am. J. Eng. Applied Sci., 4: 314-320. DOI: 10.3844 /ajeassp.2011.314.320

Jaber, A.A. and R. Bicker, 2016. Industrial robot fault detection based on statistical control chart. Am. J. Eng. Applied Sci., 9: 251-263.

DOI: 10.3844/ajeassp.2016.251.263

Jafari, N., A. Alsadoon, C.P. Withana, A. Beg and A. Elchouemi, 2016. Designing a comprehensive security framework for smartphones and mobile devices. Am. J. Eng. Applied Sci., 9: 724-734. DOI: 10.3844/ajeassp.2016.724.734

Jalil, M.I.A. and J. Sampe, 2013. Experimental investigation of thermoelectric generator modules with different technique of cooling system. Am. J. Eng. Applied Sci., 6: 1-7. DOI: 10.3844/ajeassp.2013.1.7

Jaoude, A.A. and K. El-Tawil, 2013. Analytic and nonlinear prognostic for vehicle suspension systems. Am. J. Eng. Applied Sci., 6: 42-56. DOI: 10.3844 /ajeassp.2013.42.56

Jarahi, H., 2016. Probabilistic seismic hazard deaggregation for Karaj City (Iran). Am. J. Eng. Applied Sci., 9: 520-529. DOI: 10.3844/ajeassp.2016.520.529

Jarahi, H. and S. Seifilaleh, 2016. Rock fall hazard zonation in Haraz Highway. Am. J. Eng. Applied Sci., 9: 371-379.

DOI: 10.3844/ajeassp.2016.371.379 
Jauhari, K., A. Widodo and I. Haryanto, 2016. Identification of a machine tool spindle critical frequency through modal and imbalance response analysis. Am. J. Eng. Applied Sci., 9: 213-221.

DOI: 10.3844/ajeassp.2016.213.221

Jiang, J., Q. Chen and S. Nimbalkar, 2016. Field data based method for predicting long-term settlements. Am. J. Eng. Applied Sci., 9: 466-476.

DOI: 10.3844/ajeassp.2016.466.476

Jones, J.R. and J.E. Reeve, 1974. Dynamic Response of Cam Curves Based on Sinusoidal Segments. In: Cams and cam Mechanisms, Rees Jones, J. (Ed.), MEP, London and Birmingham, Alabama.

Kaewnai, S. and S. Wongwises, 2011. Improvement of the runner design of francis turbine using computational fluid dynamics. Am. J. Eng. Applied Sci., 4: 540-547.

DOI: 10.3844/ajeassp.2011.540.547

Khalifa, A.H.N., A.H. Jabbar and J.A. Muhsin, 2015. Effect of exhaust gas temperature on the performance of automobile adsorption airconditioner. Am. J. Eng. Applied Sci., 8: 575-581. DOI: 10.3844 /ajeassp.2015.575.581

Khalil, R., 2015. Credibility of 3D volume computation using GIS for pit excavation and roadway constructions. Am. J. Eng. Applied Sci., 8: 434-442. DOI: 10.3844/ajeassp.2015.434.442

Kamble, V.G. and N. Kumar, 2016. Fabrication and tensile property analysis of polymer matrix composites of graphite and silicon carbide as fillers. Am. J. Eng. Applied Sci., 9: 17-30.

DOI: 10.3844/ajeassp.2016.17.30

Kazakov, V.V., V.I. Yusupov, V.N. Bagratashvili, A.I. Pavlikov and V.A. Kamensky, 2016. Control of bubble formation at the optical fiber tip by analyzing ultrasound acoustic waves. Am. J. Eng. Applied Sci., 9: 921-927.

DOI: 10.3844/ajeassp.2016.921.927

Kechiche, O.B.H.B., H.B.A. Sethom, H. Sammoud and I.S. Belkhodja, 2011. Optimized high-frequency signal injection based permanent magnet synchronous motor rotor position estimation applied to washing machines. Am. J. Eng. Applied Sci., 4: 390-399. DOI: 10.3844/ajeassp.2011.390.399

Koster, M.P., 1974. The Effects of Backlash and Shaft Flexibility on the Dynamic Behavior of a Cam Mechanism. In: Cams and Cam Mechanisms, Rees Jones, J. (Ed.), MEP, London and Birmingham, Alabama.

Kuli, I., T.M. Abu-Lebdeh, E.H. Fini and S.A. Hamoush, 2016. The use of nano-silica for improving mechanical properties of hardened cement paste. Am. J. Eng. Applied Sci., 9: 146-154.

DOI: 10.3844 /ajeassp.2016.146.154
Kumar, N.D., R.D. Ravali and PR. Srirekha, 2015. Design and realization of pre-amplifier and filters for on-board radar system. Am. J. Eng. Applied Sci., 8: 689-701. DOI: 10.3844/ajeassp.2015.689.701

Kunanoppadon, J., 2010. Thermal efficiency of a combined turbocharger set with gasoline engine. Am. J. Eng. Applied Sci., 3: 342-349. DOI: 10.3844/ajeassp.2010.342.349

Kwon, S., Y. Tani, H. Okubo and T. Shimomura, 2010. Fixed-star tracking attitude control of spacecraft using single-gimbal control moment gyros. Am. J. Eng. Applied Sci., 3: 49-55.

DOI: 10.3844 /ajeassp.2010.49.55

Lamarre, A., E.H. Fini and T.M. Abu-Lebdeh, 2016. Investigating effects of water conditioning on the adhesion properties of crack sealant. Am. J. Eng. Applied Sci., 9: 178-186. DOI: 10.3844/ajeassp.2016.178.186

Lee, B.J., 2013. Geometrical derivation of differential kinematics to calibrate model parameters of flexible manipulator. Int. J. Adv. Robotic Syst. DOI: $10.5772 / 55592$

Li, G. and D.S. Liu, 2010. Dynamic behavior of the forging manipulator under large amplitude compliance motion. J. Mech. Eng., 46: 21-28.

Li, R., B. Zhang, S. Xiu, H. Wang and L. Wang et al., 2015. Characterization of solid residues obtained from supercritical ethanol liquefaction of swine manure. Am. J. Eng. Applied Sci., 8: 465-470. DOI: 10.3844/ajeassp.2015.465.470

Lin, W., B. Li, X. Yang and D. Zhang, 2013. Modelling and control of inverse dynamics for a 5-DOF parallel kinematic polishing machine. Int. J. Adv. Robotic Sys. DOI: 10.5772/54966

Liu, H., W. Zhou, X. Lai and S. Zhu, 2013. An efficient inverse kinematic algorithm for a PUMA560structured robot manipulator. IJARS. DOI: $10.5772 / 56403$

Lubis, Z., A.N. Abdalla, Mortaza and R. Ghon, 2009. Mathematical modeling of the three phase induction motor couple to DC motor in hybrid electric vehicle. Am. J. Eng. Applied Sci., 2: 708-712. DOI: 10.3844/ajeassp.2009.708.712

Madani, D.A. and A. Dababneh, 2016. Rapid entire body assessment: A literature review. Am. J. Eng. Applied Sci., 9: 107-118. DOI: 10.3844/ajeassp.2016.107.118

Malomar, G.E.B., A. Gueye, C. Mbow, V.B. Traore and A.C. Beye, 2016. Numerical study of natural convection in a square porous cavity thermally modulated on both side walls. Am. J. Eng. Applied Sci., 9: 591-598. DOI: 10.3844/ajeassp.2016.591.598

Mansour, M.A.A., 2016. Developing an anthropometric database for Saudi students and comparing Saudi dimensions relative to Turkish and Iranian peoples. Am. J. Eng. Applied Sci., 9: 547-557. DOI: 10.3844/ajeassp.2016.547.557 
Maraveas, C., Z.C. Fasoulakis and K.D. Tsavdaridis, 2015. A review of human induced vibrations on footbridges. Am. J. Eng. Applied Sci., 8: 422-433. DOI: 10.3844/ajeassp.2015.422.433

Marghany, M. and M. Hashim, 2009. Robust of doppler centroid for mapping sea surface current by using radar satellite data. Am. J. Eng. Applied Sci., 2: 781-788. DOI: 10.3844/ajeassp.2009.781.788

Martins, F.R., A.R. Gonçalves and E.B. Pereira, 2016. Observational study of wind shear in northeastern Brazil. Am. J. Eng. Applied Sci., 9: 484-504. DOI: 10.3844/ajeassp.2016.484.504

Marzuki, M.A.L.B., M.H. Abd Halim and A.R.N. Mohamed, 2015. Determination of natural frequencies through modal and harmonic analysis of space frame race car chassis based on ANSYS. Am. J. Eng. Applied Sci., 8: 538-548. DOI: $10.3844 /$ ajeassp. 2015.538 .548

Mavukkandy, M.O., S. Chakraborty, T. Abbasi and S.A. Abbasi, 2016. A clean-green synthesis of platinum nanoparticles utilizing a pernicious weed lantana (Lantana Camara). Am. J. Eng. Applied Sci., 9: 8490. DOI: 10.3844/ajeassp.2016.84.90

Minghini, F., N. Tullini and F. Ascione, 2016. Updating Italian design guide CNR DT-205/2007 in view of recent research findings: Requirements for pultruded FRP profiles. Am. J. Eng. Applied Sci., 9: 702-712. DOI: 10.3844/ajeassp.2016.702.712

Moezi, N., D. Dideban and A. Ketabi, 2008. A novel integrated SET based inverter for nano power electronic applications. Am. J. Eng. Applied Sci., 1: 219-222. DOI: 10.3844/ajeassp.2008.219.222

Mohamed, M.A., A.Y. Tuama, M. Makhtar, M.K. Awang and M. Mamat, 2016. The effect of RSA exponential key growth on the multi-core computational resource. Am. J. Eng. Applied Sci., 9: 1054-1061. DOI: 10.3844/ajeassp.2016.1054.1061

Mohan, K.S.R., P. Jayabalan and A. Rajaraman, 2012. Properties of fly ash based coconut fiber composite. Am. J. Eng. Applied Sci., 5: 29-34. DOI: 10.3844/ajeassp.2012.29.34

Mohseni, E. and K.D. Tsavdaridis, 2016. Effect of nanoalumina on pore structure and durability of class f fly ash self-compacting mortar. Am. J. Eng. Applied Sci., 9: 323-333. DOI: 10.3844/ajeassp.2016.323.333

Momani, M.A., T.A. Al Smadi, FM. Al Taweel and K.A. Ghaidan, 2011. GPS ionospheric total electron content and scintillation measurements during the October 2003 magnetic storm. Am. J. Eng. Applied Sci., 4: 301-306. DOI: 10.3844/ajeassp.2011.301.306

Momta, P.S., J.O. Omoboh and M.I. Odigi, 2015. Sedimentology and depositional environment of D2 sand in part of greater ughelli depobelt, onshore Niger Delta, Nigeria. Am. J. Eng. Applied Sci., 8: 556-566. DOI: 10.3844/ajeassp.2015.556.566
Mondal, R., S. Sahoo and C.S. Rout, 2016. Mixed nickel cobalt manganese oxide nanorods for supercapacitor application. Am. J. Eng. Applied Sci., 9: 540-546. DOI: 10.3844/ajeassp.2016.540.546

Montgomery, J., T.M. Abu-Lebdeh, S.A. Hamoush and M. Picornell, 2016. Effect of nano-silica on the compressive strength of harden cement paste at different stages of hydration. Am. J. Eng. Applied Sci., 9: 166-177.

DOI: 10.3844 ajeassp.2016.166.177

Moretti, M.L., 2015. Seismic design of masonry and reinforced concrete infilled frames: A comprehensive overview. Am. J. Eng. Applied Sci., 8: 748-766. DOI: 10.3844/ajeassp.2015.748.766

Morse, A., M.M. Mansfield, R.M. Alley, H.A. Kerr and R.B. Bucinell, 2016b. Traction enhancing products affect maximum torque at the shoe-floor interface: A potential increased risk of ACL injury. Am. J. Eng. Applied Sci., 9: 889-893.

DOI: 10.3844 /ajeassp.2016.889.893

Moubarek, T. and A. Gharsallah, 2016. A six-port reflectometer calibration using Wilkinson power divider. Am. J. Eng. Applied Sci., 9: 274-280. DOI: 10.3844 /ajeassp.2016.274.280

Nabilou, A., 2016a. Effect of parameters of selection and replacement drilling bits based on geo-mechanical factors: (Case study: Gas and oil reservoir in the Southwest of Iran). Am. J. Eng. Applied Sci., 9: 380-395. DOI: 10.3844/ajeassp.2016.380.395

Nabilou, A., 2016b. Study of the parameters of Steam Assisted Gravity Drainage (SAGD) method for enhanced oil recovery in a heavy oil fractured carbonate reservoir. Am. J. Eng. Applied Sci., 9: 647-658. DOI: 10.3844/ajeassp.2016.647.658

Nachiengtai, T., W. Chim-Oye, S. Teachavorasinskun and W. Sa-Ngiamvibool, 2008. Identification of shear band using elastic shear wave propagation. Am. J. Eng. Applied Sci., 1: 188-191. DOI: 10.3844/ajeassp.2008.188.191

Nahas, R. and S.P. Kozaitis, 2014. Metric for the fusion of synthetic and real imagery from multimodal sensors. Am. J. Eng. Applied Sci., 7: 355-362. DOI: 10.3844/ajeassp.2014.355.362

Nandhakumar, S., V. Selladurai and S. Sekar, 2009. Numerical investigation of an industrial robot arm control problem using haar wavelet series. Am. J. Eng. Applied Sci., 2: 584-589.

DOI: 10.3844 /ajeassp.2009.584.589

Ng, K.C., M.Z. Yusoff, K. Munisamy, H. Hasini and N.H. Shuaib, 2008. Time-marching method for computations of high-speed compressible flow on structured and unstructured grid. Am. J. Eng. Applied Sci., 1: 89-94.

DOI: 10.3844/ajeassp.2008.89.94 
Obaiys, S.J., Z. Abbas, N.M.A. Nik Long, A.F. Ahmad and A. Ahmedov et al., 2016. On the general solution of first-kind hypersingular integral equations. Am. J. Eng. Applied Sci., 9: 195-201. DOI: 10.3844/ajeassp.2016.195.201

Odeh, S., R. Faqeh, L. Abu Eid and N. Shamasneh, 2009. Vision-based obstacle avoidance of mobile robot using quantized spatial model. Am. J. Eng. Applied Sci., 2: 611-619. DOI: 10.3844/ajeassp.2009.611.619

Ong, A.T., A. Mustapha, Z.B. Ibrahim, S. Ramli and B.C. Eong, 2015. Real-time automatic inspection system for the classification of PCB flux defects. Am. J. Eng. Applied Sci., 8: 504-518. DOI: 10.3844 /ajeassp.2015.504.518

Opafunso, Z.O., I.I. Ozigis and I.A. Adetunde, 2009. Pneumatic and hydraulic systems in coal fluidized bed combustor. Am. J. Eng. Applied Sci., 2: 88-95. DOI: 10.3844/ajeassp.2009.88.95

Orlando, N. and E. Benvenuti, 2016. Advanced XFEM simulation of pull-out and debonding of steel bars and FRP-reinforcements in concrete beams. Am. J. Eng. Applied Sci., 9: 746-754.

DOI: 10.3844/ajeassp.2016.746.754

Pannirselvam, N., P.N. Raghunath and K. Suguna, 2008. Neural network for performance of glass fibre reinforced polymer plated RC beams. Am. J. Eng. Applied Sci., 1: 82-88.

DOI: 10.3844 /ajeassp.2008.82.88

Pattanasethanon, S., 2010. The solar tracking system by using digital solar position sensor. Am. J. Eng. Applied Sci., 3: 678-682. DOI: 10.3844/ajeassp.2010.678.682

Pérez-de León, G., V.E. Lamberti, R.D. Seals, T.M. Abu-Lebdeh and S.A. Hamoush, 2016. Gas atomization of molten metal: Part I. Numerical modeling conception. Am. J. Eng. Applied Sci., 9: 303-322. DOI: 10.3844/ajeassp.2016.303.322

Padula, F. and V. Perdereau, 2013. An on-line path planner for industrial manipulators. Int. J. Adv. Robotic Sys. DOI: 10.5772/55063

Perumaal, S. and N. Jawahar, 2013. Automated trajectory planner of industrial robot for pick-andplace task. IJARS. DOI: 10.5772/53940

Petrescu, F. and R. Petrescu, 1995a. Contributions to optimization of the polynomial motion laws of the stick from the internal combustion engine distribution mechanism. Bucharest, 1: 249-256.

Petrescu, F. and R. Petrescu, 1995b. Contributions to the synthesis of internal combustion engine distribution mechanisms. Bucharest, 1: 257-264.

Petrescu, F. and R. Petrescu, 1997a. Dynamics of cam mechanisms (exemplified on the classic distribution mechanism). Bucharest, 3: 353-358.

Petrescu, F. and R. Petrescu, 1997b. Contributions to the synthesis of the distribution mechanisms of internal combustion engines with a Cartesian coordinate method. Bucharest, 3: 359-364.
Petrescu, F. and R. Petrescu, 1997c. Contributions to maximizing polynomial laws for the active stroke of the distribution mechanism from internal combustion engines. Bucharest, 3: 365-370.

Petrescu, F. and R. Petrescu, 2000a. Synthesis of distribution mechanisms by the rectangular (Cartesian) coordinate method. Proceedings of the 8th National Conference on International Participation, (CIP' 00), Craiova, Romania, pp: 297-302.

Petrescu, F. and R. Petrescu, 2000b. The design (synthesis) of cams using the polar coordinate method (triangle method). Proceedings of the 8th National Conference on International Participation, (CIP' 00), Craiova, Romania, pp: 291-296.

Petrescu, F. and R. Petrescu, 2002a. Motion laws for cams. Proceedings of the International Computer Assisted Design, National Symposium with Participation, (SNP' 02), Braşov, pp: 321-326.

Petrescu, F. and R. Petrescu, 2002b. Camshaft dynamics elements. Proceedings of the International Computer Assisted Design, National Participation Symposium, (SNP' 02), Braşov, pp: 327-332.

Petrescu, F. and R. Petrescu, 2003. Some elements regarding the improvement of the engine design. Proceedings of the National Symposium, Descriptive Geometry, Technical Graphics and Design, (GTD' 03), Braşov, pp: 353-358.

Petrescu, F. and R. Petrescu, 2005a. The cam design for a better efficiency. Proceedings of the International Conference on Engineering Graphics and Design, (EGD' 05), Bucharest, pp: 245-248.

Petrescu, F. and R. Petrescu, 2005b. Contributions at the dynamics of cams. Proceedings of the 9th IFToMM International Symposium on Theory of Machines and Mechanisms, (TMM' 05), Bucharest, Romania, pp: 123-128.

Petrescu, F. and R. Petrescu, 2005c. Determining the dynamic efficiency of cams. Proceedings of the 9th IFToMM International Symposium on Theory of Machines and Mechanisms, (TMM' 05), Bucharest, Romania, pp: 129-134.

Petrescu, F. and R. Petrescu, 2005d. An original internal combustion engine. Proceedings of the 9th IFToMM International Symposium on Theory of Machines and Mechanisms, (TMM' 05), Bucharest, Romania, pp: 135-140.

Petrescu, F. and R. Petrescu, 2005e. Determining the mechanical efficiency of Otto engine's mechanism. Proceedings of the 9th IFToMM International Symposium on Theory of Machines and Mechanisms, (TMM 05), Bucharest, Romania, pp: 141-146.

Petrescu, F.I. and R.V. Petrescu, 2011a. Mechanical Systems, Serial and Parallel (Romanian). 1st Edn., LULU Publisher, London, UK, pp: 124.

Petrescu, FIT. and RV. Petrescu, 2011b. Trenuri Planetare. 1st Edn., Createspace Independent Pub., ISBN-13: 978-1468030419, pp: 104. 
Petrescu, F.I. and R.V. Petrescu, 2012a. Kinematics of the planar quadrilateral mechanism. ENGEVISTA, 14: 345-348.

Petrescu, F.I. and R.V. Petrescu, 2012b. MecatronicaSisteme Seriale si Paralele. 1st Edn., Create Space Publisher, USA, pp: 128.

Petrescu, F.I. and R.V. Petrescu, 2013a. Cinematics of the 3R dyad. ENGEVISTA, 15: 118-124.

Petrescu, F.I.T. and R.V. Petrescu, 2013b. Forces and efficiency of cams. Int. Rev. Mech. Eng., 7: 507-511.

Petrescu, F.I.T. and R.V. Petrescu, 2013c. Cams with high efficiency. Int. Rev. Mech. Eng., 7: 599-606.

Petrescu, F.I.T. and R.V. Petrescu, 2013d. An algorithm for setting the dynamic parameters of the classic distribution mechanism. Int. Rev. Modell. Simulat., 6: 1637-1641.

Petrescu, F.I.T. and R.V. Petrescu, 2013e. Dynamic synthesis of the rotary cam and translated tappet with roll. Int. Rev. Modell. Simulat., 6: 600-607.

Petrescu, F.I.T. and R.V. Petrescu, 2014a. Parallel moving mechanical systems. Independent J. Manage. Product., 5: 564-580.

Petrescu, F.I.T. and R.V. Petrescu, 2014b. Cam gears dynamics in the classic distribution. Independent $\mathrm{J}$. Manage. Product., 5: 166-185.

Petrescu, F.I.T. and R.V. Petrescu, 2014c. Highefficiency gears synthesis by avoid the interferences. Independent J. Manage. Product., 5: 275-298.

Petrescu, F.I.T. and R.V. Petrescu, 2014d. Gear design. J. ENGEVISTA, 16: 313-328.

Petrescu, F.I.T. and R.V. Petrescu, 2014e. Kinetostatic of the $3 \mathrm{R}$ dyad (or $2 \mathrm{R}$ module). J. ENGEVISTA, 16: 314-321.

Petrescu, F.I.T. and R.V. Petrescu, 2014f. Balancing Otto engines. Int. Rev. Mech. Eng., 8: 473-480.

Petrescu, F.I.T. and R.V. Petrescu, 2014g. Machine equations to the classical distribution. Int. Rev. Mech. Eng., 8: 309-316.

Petrescu, F.I.T. and R.V. Petrescu, 2014h. Forces of internal combustion heat engines. Int. Rev. Modell. Simulat., 7: 206-212.

Petrescu, F.I.T. and R.V. Petrescu, 2014i. Determination of the yield of internal combustion thermal engines. Int. Rev. Mech. Eng., 8: 62-67.

Petrescu, F.I.T. and R.V. Petrescu, 2015a. Forces at the main mechanism of a railbound forging manipulator. Independent J. Manage. Product., 6: 904-921.

Petrescu, F.I.T. and R.V. Petrescu, 2015b. Kinematics at the main mechanism of a railbound forging manipulator. Independent J. Manage. Product., 6: 711-729.

Petrescu, F.I.T. and R.V. Petrescu, 2015c. Machine motion equations. Independent J. Manage. Product., 6: 773-802.
Petrescu F.I.T. and R.V. Petrescu, 2015d. Presenting a railbound forging manipulator. Applied Mech. Mater., 762: 219-224.

Petrescu, F.I.T. and R.V. Petrescu, 2015e. About the anthropomorphic robots. J. ENGEVISTA, 17: 1-15.

Petrescu, F.I. and R.V. Petrescu, 2016a. Parallel moving mechanical systems kinematics. ENGEVISTA, 18: 455-491.

Petrescu, F.I. and R.V. Petrescu, 2016b. Direct and inverse kinematics to the anthropomorphic robots. ENGEVISTA, 18: 109-124.

Petrescu, F.I. and R.V. Petrescu, 2016c. Dynamic cinematic to a structure 2R. Revista Geintec-Gestao Inovacao E Tecnol., 6: 3143-3154.

Petrescu, FIT. and R.V. Petrescu, 2016d. An Otto engine dynamic model. Independent J. Manage. Product., 7: 038-048.

Petrescu, R.V., R. Aversa, A. Apicella and F.I. Petrescu, 2016. Future medicine services robotics. Am. J. Eng. Applied Sci., 9: 1062-1087. DOI: 10.3844/ajeassp.2016.1062.1087

Petrescu, F.I., B. Grecu, A. Comanescu and R.V. Petrescu, 2009. Some mechanical design elements. Proceeding of the International Conference on Computational Mechanics and Virtual Engineering, (MVE' 09), Braşov, pp: 520-525.

Petrescu, F.I.T., 2008. Theoretical and applied contributions about the dynamic of planar mechanisms with superior linkages. Ph.D. Thesis, Bucharest Polytechnic University.

Petrescu, F.I.T., 2011. Teoria Mecanismelor si a Masinilor: Curs Si Aplicatii. 1st Edn., CreateSpace Independent Publishing Platform. ISBN-10: 1468015826. pp: 432.

Petrescu, F.I.T., 2015a. Geometrical synthesis of the distribution mechanisms. Am. J. Eng. Applied Sci., 8: 63-81. DOI: 10.3844/ajeassp.2015.63.81

Petrescu, F.I.T., 2015b. Machine motion equations at the internal combustion heat engines. Am. J. Eng. Applied Sci., 8: 127-137. DOI: 10.3844 /ajeassp.2015.127.137

Petrescu, F.I.T., A. Apicella, A. Raffaella, RV. Petrescu and J.K. Calautit et al., 2016. Something about the mechanical moment of inertia. Am. J. Applied Sci., 13: $1085-1090$.

DOI: 10.3844/ajassp.2016.1085.1090

Petrescu, R.V., R. Aversa, B. Akash, R. Bucinell and J. Corchado et al., 2017a. Yield at thermal engines internal combustion. Am. J. Eng. Applied Sci., 10: 243-251. DOI: 10.3844/ajeassp.2017.243.251

Petrescu, R.V., R. Aversa, B. Akash, B. Ronald and J. Corchado et al., 2017b. Velocities and accelerations at the 3R mechatronic systems. Am. J. Eng. Applied Sci., 10: 252-263.

DOI: 10.3844/ajeassp.2017.252.263 
Petrescu, R.V., R. Aversa, B. Akash, R. Bucinell and J. Corchado et al., 2017c. Anthropomorphic solid structures n-r kinematics. Am. J. Eng. Applied Sci., 10: 279-291. DOI: 10.3844/ajeassp.2017.279.291

Petrescu, R.V., R. Aversa, B. Akash, R. Bucinell and J. Corchado et al., 2017d. Inverse kinematics at the anthropomorphic robots, by a trigonometric method. Am. J. Eng. Applied Sci., 10: 394-411.

DOI: 10.3844/ajeassp.2017.394.411

Petrescu, R.V., R. Aversa, B. Akash, R. Bucinell and J. Corchado et al., 2017e. Forces at internal combustion engines. Am. J. Eng. Applied Sci., 10: 382-393. DOI: 10.3844/ajeassp.2017.382.393

Petrescu, R.V., R. Aversa, B. Akash, R. Bucinell and J. Corchado et al., 2017f. Gears-Part I. Am. J. Eng. Applied Sci., 10: 457-472.

DOI: 10.3844/ajeassp.2017.457.472

Petrescu, R.V., R. Aversa, B. Akash, R. Bucinell and J. Corchado et al., 2017g. Gears-part II. Am. J. Eng. Applied Sci., 10: 473-483.

DOI: 10.3844/ajeassp.2017.473.483

Petrescu, R.V., R. Aversa, B. Akash, R. Bucinell and J. Corchado et al., 2017h. Cam-gears forces, velocities, powers and efficiency. Am. J. Eng. Applied Sci., 10: 491-505. DOI: 10.3844/ajeassp.2017.491.505

Petrescu, R.V., R. Aversa, B. Akash, R. Bucinell and J. Corchado et al., 2017i. Dynamics of mechanisms with cams illustrated in the classical distribution. Am. J. Eng. Applied Sci., 10: 551-567. DOI: 10.3844/ajeassp.2017.551.567

Petrescu, R.V., R. Aversa, B. Akash, R. Bucinell and J. Corchado et al., 2017j. Testing by non-destructive control. Am. J. Eng. Applied Sci., 10: 568-583. DOI: 10.3844 /ajeassp.2017.568.583

Petrescu, R.V., R. Aversa, A. Apicella and F.I.T. Petrescu, 2017k. Transportation engineering. Am. J. Eng. Applied Sci., 10: 685-702. DOI: 10.3844/ajeassp.2017.685.702

Petrescu, R.V., R. Aversa, S. Kozaitis, A. Apicella and F.I.T. Petrescu, 20171. The quality of transport and environmental protection, part I. Am. J. Eng. Applied Sci., 10: 738-755. DOI: 10.3844/ajeassp.2017.738.755

Petrescu, R.V., R. Aversa, B. Akash, R. Bucinell and J. Corchado et al., $2017 \mathrm{~m}$. Modern propulsions for aerospace-a review. J. Aircraft Spacecraft Technol., 1: 1-8. DOI: $10.3844 /$ jastsp.2017.1.8

Petrescu, R.V., R. Aversa, B. Akash, R. Bucinell and J. Corchado et al., 2017n. Modern propulsions for aerospace-part II. J. Aircraft Spacecraft Technol., 1: 9-17. DOI: 10.3844/jastsp.2017.9.17

Petrescu, R.V., R. Aversa, B. Akash, R. Bucinell and J. Corchado et al., 2017o. History of aviation-a short review. J. Aircraft Spacecraft Technol., 1: 30-49. DOI: 10.3844 jastsp.2017.30.49
Petrescu, R.V., R. Aversa, B. Akash, R. Bucinell and J. Corchado et al., 2017p. Lockheed martin-a short review. J. Aircraft Spacecraft Technol., 1: 50-68. DOI: $10.3844 /$ jastsp.2017.50.68

Petrescu, R.V., R. Aversa, B. Akash, J. Corchado and F. Berto et al., 2017q. Our universe. J. Aircraft Spacecraft Technol., 1: 69-79. DOI: 10.3844/jastsp.2017.69.79

Petrescu, R.V., R. Aversa, B. Akash, J. Corchado and F. Berto et al., 2017r. What is a UFO? J. Aircraft Spacecraft Technol., 1: 80-90. DOI: $10.3844 /$ jastsp.2017.80.90

Petrescu, R.V., R. Aversa, B. Akash, J. Corchado and F. Berto et al., 2017s. About bell helicopter FCX-001 concept aircraft-a short review. J. Aircraft Spacecraft Technol., 1: 91-96. DOI: 10.3844 jastsp.2017.91.96

Petrescu, R.V., R. Aversa, B. Akash, J. Corchado and F. Berto et al., 2017t. Home at airbus. J. Aircraft Spacecraft Technol., 1: 97-118. DOI: $10.3844 /$ jastsp.2017.97.118

Petrescu, R.V., R. Aversa, B. Akash, J. Corchado and F. Berto et al., 2017u. Airlander. J. Aircraft Spacecraft Technol., 1: 119-148. DOI: 10.3844/jastsp.2017.119.148

Petrescu, R.V., R. Aversa, B. Akash, J. Corchado and F. Berto et al., 2017v. When boeing is dreaming-a review. J. Aircraft Spacecraft Technol., 1: 149-161. DOI: $10.3844 /$ jastsp.2017.149.161

Petrescu, R.V., R. Aversa, B. Akash, J. Corchado and F. Berto et al., 2017w. About Northrop Grumman. J. Aircraft Spacecraft Technol., 1: 162-185. DOI: $10.3844 /$ jastsp.2017.162.185

Petrescu, R.V., R. Aversa, B. Akash, J. Corchado and F. Berto et al., 2017x. Some special aircraft. J. Aircraft Spacecraft Technol., 1: 186-203. DOI: 10.3844 /jastsp.2017.186.203

Petrescu, R.V., R. Aversa, B. Akash, J. Corchado and F. Berto et al., 2017y. About helicopters. J. Aircraft Spacecraft Technol., 1: 204-223. DOI: 10.3844 /jastsp.2017.204.223

Petrescu, R.V., R. Aversa, B. Akash, F. Berto and A. Apicella et al., 2017z. The modern flight. J. Aircraft Spacecraft Technol., 1: 224-233. DOI: 10.3844 /jastsp.2017.224.233

Petrescu, R.V., R. Aversa, B. Akash, F. Berto and A. Apicella et al., 2017aa. Sustainable energy for aerospace vessels. J. Aircraft Spacecraft Technol., 1: 234-240. DOI: 10.3844/jastsp.2017.234.240

Petrescu, R.V., R. Aversa, B. Akash, F. Berto and A. Apicella et al., 2017ab. Unmanned helicopters. J. Aircraft Spacecraft Technol., 1: 241-248. DOI: $10.3844 /$ jastsp.2017.241.248

Petrescu, R.V., R. Aversa, B. Akash, F. Berto and A. Apicella et al., 2017ac. Project HARP. J. Aircraft Spacecraft Technol., 1: 249-257. DOI: $10.3844 /$ jastsp.2017.249.257 
Petrescu, R.V., R. Aversa, B. Akash, F. Berto and A. Apicella et al., 2017ad. Presentation of Romanian engineers who contributed to the development of global aeronautics-part I. J. Aircraft Spacecraft Technol., 1: 258-271. DOI: 10.3844 /jastsp.2017.258.271

Petrescu, R.V., R. Aversa, B. Akash, F. Berto and A. Apicella et al., 2017ae. A first-class ticket to the planet mars, please. J. Aircraft Spacecraft Technol., 1: 272-281. DOI: $10.3844 /$ jastsp.2017.272.281

Petrescu, R.V., R. Aversa, A. Apicella, M.M. Mirsayar and S. Kozaitis et al., 2018a. NASA started a propeller set on board voyager 1 after 37 years of break. Am. J. Eng. Applied Sci., 11: 66-77.

DOI: 10.3844/ajeassp.2018.66.77

Petrescu, R.V., R. Aversa, A. Apicella, M.M. Mirsayar and S. Kozaitis et al., 2018b. There is life on mars? Am. J. Eng. Applied Sci., 11: 78-91.

DOI: 10.3844/ajeassp.2018.78.91

Petrescu, R.V., R. Aversa, A. Apicella and F.I.T. Petrescu, 2018c. Friendly environmental transport. Am. J. Eng. Applied Sci., 11: 154-165. DOI: 10.3844/ajeassp.2018.154.165

Petrescu, R.V., R. Aversa, B. Akash, T.M. Abu-Lebdeh and A. Apicella et al., 2018d. Buses running on gas. Am. J. Eng. Applied Sci., 11: 186-201.

DOI: 10.3844/ajeassp.2018.186.201

Petrescu, R.V., R. Aversa, B. Akash, T.M. Abu-Lebdeh and A. Apicella et al., 2018e. Some aspects of the structure of planar mechanisms. Am. J. Eng. Applied Sci., 11: 245-259.

DOI: 10.3844/ajeassp.2018.245.259

Petrescu, RV., R. Aversa, T.M. Abu-Lebdeh, A. Apicella and F.I.T. Petrescu, 2018f. The forces of a simple carrier manipulator. Am. J. Eng. Applied Sci., 11: 260-272.

DOI: 10.3844 ajeassp.2018.260.272

Petrescu, RV., R. Aversa, T.M. Abu-Lebdeh, A. Apicella and F.I.T. Petrescu, 2018g. The dynamics of the otto engine. Am. J. Eng. Applied Sci., 11: 273-287. DOI: 10.3844/ajeassp.2018.273.287

Petrescu, RV., R. Aversa, T.M. Abu-Lebdeh, A. Apicella and F.I.T. Petrescu, 2018h. NASA satellites help us to quickly detect forest fires. Am. J. Eng. Applied Sci., 11: 288-296.

DOI: 10.3844 /ajeassp.2018.288.296

Petrescu, RV., R. Aversa, T.M. Abu-Lebdeh, A. Apicella and F.I.T. Petrescu, 2018i. Kinematics of a mechanism with a triad. Am. J. Eng. Applied Sci., 11: 297-308. DOI: 10.3844/ajeassp.2018.297.308

Petrescu, R.V., R. Aversa, A. Apicella and F.I.T. Petrescu, 2018j. Romanian engineering "on the wings of the wind". J. Aircraft Spacecraft Technol., 2: 1-18. DOI: $10.3844 /$ jastsp.2018.1.18
Petrescu, R.V., R. Aversa, A. Apicella and F.I.T. Petrescu, 2018k. NASA Data used to discover eighth planet circling distant star. J. Aircraft Spacecraft Technol., 2: 19-30. DOI: 10.3844 jastsp.2018.19.30

Petrescu, R.V., R. Aversa, A. Apicella and F.I.T. Petrescu, 20181. NASA has found the most distant black hole. J. Aircraft Spacecraft Technol., 2: 31-39. DOI: 10.3844 jastsp.2018.31.39

Petrescu, R.V., R. Aversa, A. Apicella and F.I.T. Petrescu, 2018m. Nasa selects concepts for a new mission to titan, the moon of saturn. J. Aircraft Spacecraft Technol., 2: 40-52. DOI: 10.3844 jastsp. 2018.40 .52

Petrescu, R.V., R. Aversa, A. Apicella and F.I.T. Petrescu, 2018n. NASA sees first in 2018 the direct proof of ozone hole recovery. J. Aircraft Spacecraft Technol., 2: 53-64. DOI: 10.3844/jastsp.2018.53.64

Pisello, A.L., G. Pignatta, C. Piselli, V.L. Castaldo and F. Cotana, 2016. Investigating the dynamic thermal behavior of building envelope in summer conditions by means of in-field continuous monitoring. Am. J. Eng. Applied Sci., 9: 505-519.

DOI: 10.3844/ajeassp.2016.505.519

Pourmahmoud, N., 2008. Rarefied gas flow modeling inside rotating circular cylinder. Am. J. Eng. Applied Sci., 1: 62-65.

DOI: 10.3844/ajeassp.2008.62.65

Pravettoni, M., C.S.P. Lòpez and R.P. Kenny, 2016. Impact of the edges of a backside diffusive reflector on the external quantum efficiency of luminescent solar concentrators: Experimental and computational approach. Am. J. Eng. Applied Sci., 9: 53-63. DOI: 10.3844 /ajeassp.2016.53.63

Qutbodin, K., 2010. Merging autopilot/flight control and navigation-flight management systems. Am. J. Eng. Applied Sci., 3: 629-630. DOI: 10.3844 /ajeassp.2010.629.630

Rajbhandari, S., Z. Ghassemlooy and M. Angelova, 2011. The performance of a dual header pulse interval modulation in the presence of artificial light interferences in an indoor optical wireless communications channel with wavelet denoising. Am. J. Eng. Applied Sci., 4: 513-519. DOI: 10.3844/ajeassp.2011.513.519

Rajput, R.S., S. Pandey and S. Bhadauria, 2016. Correlation of biodiversity of algal genera with special reference to the waste water effluents from industries. Am. J. Eng. Applied Sci., 9: 1127-1133. DOI: 10.3844/ajeassp.2016.1127.1133

Rajupillai, K., S. Palaniammal and K. Bommuraju, 2015. Computational intelligence and application of frame theory in communication systems. Am. J. Eng. Applied Sci., 8: 633-637.

DOI: 10.3844 /ajeassp.2015.633.637 
Raptis, K.G., G.A. Papadopoulos, T.N. Costopoulos and A.D. Tsolakis, 2011. Experimental study of load sharing in roller-bearing contact by caustics and photoelasticity. Am. J. Eng. Applied Sci., 4: 294300. DOI: 10.3844 /ajeassp.2011.294.300

Rama, G., D. Marinkovic and M. Zehn, 2016. Efficient co-rotational 3-node shell element. Am. J. Eng. Applied Sci., 9: 420-431.

DOI: 10.3844/ajeassp.2016.420.431

Rea, P. and E. Ottaviano, 2016. Analysis and mechanical design solutions for sit-to-stand assisting devices. Am. J. Eng. Applied Sci., 9: 1134-1143. DOI: 10.3844/ajeassp.2016.1134.1143

Rhode-Barbarigos, L., V. Charpentier, S. Adriaenssens and O. Baverel, 2015. Dialectic form finding of structurally integrated adaptive structures. Am. J. Eng. Applied Sci., 8: 443-454. DOI: 10.3844/ajeassp.2015.443.454

Riccio, A., U. Caruso, A. Raimondo and A. Sellitto, 2016a. Robustness of XFEM method for the simulation of cracks propagation in fracture mechanics problems. Am. J. Eng. Applied Sci., 9: 599-610. DOI: 10.3844/ajeassp.2016.599.610

Riccio, A., R. Cristiano and S. Saputo, 2016b. A brief introduction to the bird strike numerical simulation. Am. J. Eng. Applied Sci., 9: 946-950. DOI: 10.3844 /ajeassp.2016.946.950

Rich, F. and M.A. Badar, 2016. Statistical analysis of auto dilution Vs manual dilution process in inductively coupled plasma spectrometer tests. Am. J. Eng. Applied Sci., 9: 611-624. DOI: 10.3844/ajeassp.2016.611.624

Rohit, K. and S. Dixit, 2016. Mechanical properties of waste Biaxially Oriented Polypropylene metallized films (BOPP), LLDPE: LDPE films with sisal fibres. Am. J. Eng. Applied Sci., 9: 913-920. DOI: 10.3844/ajeassp.2016.913.920

Rulkov, N.F., A.M. Hunt, P.N. Rulkov and A.G. Maksimov, 2016. Quantization of map-based neuronal model for embedded simulations of neurobiological networks in real-time. Am. J. Eng. Applied Sci., 9: 973-984. DOI: 10.3844/ajeassp.2016.973.984

Saikia, A. and N. Karak, 2016. Castor oil based epoxy/clay nanocomposite for advanced applications. Am. J. Eng. Applied Sci., 9: 31-40. DOI: 10.3844/ajeassp.2016.31.40

Sallami, A., N. Zanzouri and M. Ksouri, 2016. Robust diagnosis of a DC motor by bond graph approach. Am. J. Eng. Applied Sci., 9: 432-438. DOI: 10.3844/ajeassp.2016.432.438

Samantaray, K.S., S. Sahoo and C.S. Rout, 2016. Hydrothermal synthesis of CuWO4-reduced graphene oxide hybrids and supercapacitor application. Am. J. Eng. Applied Sci., 9: 584-590. DOI: 10.3844/ajeassp.2016.584.590
Santos, F.A. and C. Bedon, 2016. Preliminary experimental and finite-element numerical assessment of the structural performance of SMAreinforced GFRP systems. Am. J. Eng. Applied Sci., 9: 692-701. DOI: 10.3844/ajeassp.2016.692.701

Sava, I., 1970. Contributions to dynamics and optimization of income mechanism synthesis. Ph.D. Thesis, I.P.B.

Semin, A.R. Ismail and R.A. Bakar, 2009a. Combustion temperature effect of diesel engine convert to compressed natural gas engine. Am. J. Eng. Applied Sci., 2: 212-216. DOI: 10.3844 ajeassp.2009.212.216

Semin, A.R. Ismail and R.A. Bakar, 2009b. Effect of diesel engine converted to sequential port injection compressed natural gas engine on the cylinder pressure Vs crank angle in variation engine speeds. Am. J. Eng. Applied Sci., 2: 154-159.

DOI: 10.3844/ajeassp.2009.154.159

Semin S., A.R. Ismail and R.A. Bakar, 2009c. Diesel engine convert to port injection $\mathrm{CNG}$ engine using gaseous injector nozzle multi holes geometries improvement: A review. Am. J. Eng. Applied Sci., 2: 268-278. DOI: 10.3844/ajeassp.2009.268.278

Semin and R.A. Bakar, 2008. A technical review of compressed natural gas as an alternative fuel for internal combustion engines. Am. J. Eng. Applied Sci., 1: 302-311.

DOI: 10.3844 /ajeassp.2008.302.311

Sepúlveda, J.A.M., 2016. Outlook of municipal solid waste in Bogota (Colombia). Am. J. Eng. Applied Sci., 9: 477-483.

DOI: 10.3844/ajeassp.2016.477.483

Serebrennikov, A., D. Serebrennikov and Z. Hakimov, 2016. Polyethylene pipeline bending stresses at an installation. Am. J. Eng. Applied Sci., 9: 350-355. DOI: 10.3844 /ajeassp.2016.350.355

Shanmugam, K., 2016. Flow dynamic behavior of fish oil/silver nitrate solution in mini-channel, effect of alkane addition on flow pattern and interfacial tension. Am. J. Eng. Applied Sci., 9: 236-250. DOI: 10.3844/ajeassp.2016.236.250

Shruti, 2016. Comparison in cover media under stegnography: Digital media by hide and seek approach. Am. J. Eng. Applied Sci., 9: 297-302. DOI: 10.3844/ajeassp.2016.297.302

Stavridou, N., E. Efthymiou and C.C. Baniotopoulos, 2015a. Welded connections of wind turbine towers under fatigue loading: Finite element analysis and comparative study. Am. J. Eng. Applied Sci., 8: 489-503. DOI: 10.3844/ajeassp.2015.489.503

Stavridou, N., E. Efthymiou and C.C. Baniotopoulos, $2015 \mathrm{~b}$. Verification of anchoring in foundations of wind turbine towers. Am. J. Eng. Applied Sci., 8: 717-729. DOI: 10.3844/ajeassp.2015.717.729 
Suarez, L., T.M. Abu-Lebdeh, M. Picornell and S.A. Hamoush, 2016. Investigating the role of fly ash and silica fume in the cement hydration process. Am. J. Eng. Applied Sci., 9: 134-145.

DOI: 10.3844/ajeassp.2016.134.145

Syahrullah, O.I. and N. Sinaga, 2016. Optimization and prediction of motorcycle injection system performance with feed-forward back-propagation method Artificial Neural Network (ANN). Am. J. Eng. Applied Sci., 9: 222-235. DOI: 10.3844/ajeassp.2016.222.235

Sylvester, O., I. Bibobra and O.N. Ogbon, 2015a. Well test and PTA for reservoir characterization of key properties. Am. J. Eng. Applied Sci., 8: 638-647. DOI: 10.3844/ajeassp.2015.638.647

Sylvester, O., I. Bibobra and O. Augustina, 2015b. Report on the evaluation of Ugua J2 and J3 reservoir performance. Am. J. Eng. Applied Sci., 8: 678-688. DOI: 10.3844/ajeassp.2015.678.688

Taher, S.A., R. Hematti and M. Nemati, 2008. Comparison of different control strategies in GAbased optimized UPFC controller in electric power systems. Am. J. Eng. Applied Sci., 1: 45-52. DOI: 10.3844/ajeassp.2008.45.52

Takeuchi, T., Y. Kinouchi, R. Matsui and T. Ogawa, 2015. Optimal arrangement of energy-dissipating members for seismic retrofitting of truss structures. Am. J. Eng. Applied Sci., 8: 455-464. DOI: 10.3844/ajeassp.2015.455.464

Taraza, D., N.A. Henein and W. Bryzik, 2001. The frequency analysis of the crankshaft's speed variation: A reliable tool for diesel engine diagnosis. J. Eng. Gas Turbines Power, 123: 428-432. DOI: $10.1115 / 1.1359479$

Tesar, D. and G.K. Matthew, 1974. The Design of Modeled Cam Systems. In: Cams and Cam Mechanisms, Rees Jones, J. (Ed.), MEP, London and Birmingham, Alabama.

Theansuwan, W. and K. Triratanasirichai, 2011. The biodiesel production from roast Thai sausage oil by transesterification reaction. Am. J. Eng. Applied Sci., 4: 130-132.

DOI: 10.3844/ajeassp.2011.130.132

Thongwan, T., A. Kangrang and S. Homwuttiwong, 2011. An estimation of rainfall using fuzzy setgenetic algorithms model. Am. J. Eng. Applied Sci., 4: 77-81. DOI: 10.3844/ajeassp.2011.77.81

Tourab, W., A. Babouri and M. Nemamcha, 2011. Experimental study of electromagnetic environment in the vicinity of high voltage lines. Am. J. Eng. Applied Sci., 4: 209-213. DOI: 10.3844/ajeassp.2011.209.213

Tsolakis, A.D. and K.G. Raptis, 2011. Comparison of maximum gear-tooth operating bending stresses derived from niemann's analytical procedure and the finite element method. Am. J. Eng. Applied Sci., 4: 350-354. DOI: 10.3844/ajeassp.2011.350.354
Vernardos, S.M. and C.J. Gantes, 2015. Cross-section optimization of sandwich-type cylindrical wind turbine towers. Am. J. Eng. Applied Sci., 8: 471480. DOI: 10.3844/ajeassp.2015.471.480

Wang, L., T. Liu, Y. Zhang and X. Yuan, 2016. A methodology for continuous evaluation of cloud resiliency. Am. J. Eng. Applied Sci., 9: 264-273. DOI: 10.3844/ajeassp.2016.264.273

Wang, L., G. Wang and C.A. Alexander, 2015. Confluences among big data, finite element analysis and high-performance computing. Am. J. Eng. Applied Sci., 8: 767-774. DOI: 10.3844/ajeassp.2015.767.774

Wang, J. and Y. Yagi, 2016. Fragment-based visual tracking with multiple representations. Am. J. Eng. Applied Sci., 9: 187-194.

DOI: 10.3844/ajeassp.2016.187.194

Waters, C., S. Ajinola and M. Salih, 2016. Dissolution sintering technique to create porous copper with sodium chloride using polyvinyl alcohol solution through powder metallurgy. Am. J. Eng. Applied Sci. 9: 155-165. DOI: 10.3844/ajeassp.2016.155.165

Wessels, L. and H. Raad, 2016. Recent advances in point of care diagnostic tools: A review. Am. J. Eng. Applied Sci., 9: 1088-1095. DOI: 10.3844/ajeassp.2016.1088.1095

Wiederrich, J.L. and B. Roth, 1974. Design of Low Vibration Cam Profiles. In: Cams and Cam Mechanisms, Rees Jones, J. (Ed.), MEP, London and Birmingham, Alabama.

Yan, C., F. Gao and W. Guo, 2009. Coordinated kinematic modeling for motion planning of heavyduty manipulators in an integrated open-die forging center. J. Eng. Manufacture, 223: 1299-1313.

Yang, M.F. and Y. Lin, 2015. Process is unreliable and quantity discounts supply chain integration inventory model. Am. J. Eng. Applied Sci., 8: 602610. DOI: 10.3844/ajeassp.2015.602.610

Yeargin, R., R. Ramey and C. Waters, 2016. Porosity analysis in porous brass using dual approaches. Am. J. Eng. Applied Sci., 9: 91-97. DOI: 10.3844/ajeassp.2016.91.97

You, M., X. Huang, M. Lin, Q. Tong and X. Li et al., 2016. Preparation of $\mathrm{LiCoMnO}_{4}$ assisted by hydrothermal approach and its electrochemical performance. Am. J. Eng. Applied Sci., 9: 396-405. DOI: 10.3844/ajeassp.2016.396.405

Zeferino, R.S., J.A.R. Ramón, E. de Anda Reyes, R.S. González and U. Pal, 2016. Large scale synthesis of $\mathrm{ZnO}$ nanostructures of different morphologies through solvent-free mechanochemical synthesis and their application in photocatalytic dye degradation. Am. J. Eng. Applied Sci., 9: 41-52. DOI: 10.3844 /ajeassp.2016.41.52

Zhao, K., H. Wang, G.L. Chen, Z.Q. Lin and Y.B. He, 2010. Compliance process analysis for forging manipulator. J. Mech. Eng., 46: 27-34. 
Zhao, B., 2013. Identification of multi-cracks in the gate rotor shaft based on the wavelet finite element method. Am. J. Eng. Applied Sci., 6: 309-319.

DOI: 10.3844/ajeassp.2013.309.319

Zheng, H. and S. Li, 2016. Fast and robust maximum power point tracking for solar photovoltaic systems. Am. J. Eng. Applied Sci., 9: 755-769.

DOI: 10.3844/ajeassp.2016.755.769

Zotos, I.S. and T.N. Costopoulos, 2009. On the use of rolling element bearings' models in Precision maintenance. Am. J. Eng. Applied Sci., 2: 344-352. DOI: 10.3844/ajeassp.2009.344.352

Zulkifli, R., K. Sopian, S. Abdullah and M.S. Takriff, 2008. Effect of pulsating circular hot air jet frequencies on local and average nusselt number. Am. J. Eng. Applied Sci., 1: 57-61. DOI: 10.3844/ajeassp.2008.57.61

Zulkifli, R., K. Sopian, S. Abdullah and M.S. Takriff, 2009. Experimental study of flow structures of circular pulsating air jet. Am. J. Eng. Applied Sci., 2: 171-175. DOI: 10.3844/ajeassp.2009.171.175

Zurfi, A. and J. Zhang, 2016a. Model identification and wall-plug efficiency measurement of white LED modules. Am. J. Eng. Applied Sci., 9: 412-419. DOI: 10.3844/ajeassp.2016.412.419

Zurfi, A. and J. Zhang, 2016b. Exploitation of battery energy storage in load frequency control-a literature survey. Am. J. Eng. Applied Sci., 9: 1173-1188. DOI: 10.3844 /ajeassp.2016.1173.1188

\section{Source of Figures}

Figure

1:

https://upload.wikimedia.org/wikipedia/commons/thumb /7/70/Viking_Lander_Model.jpg/1024px-

Viking_Lander_Model.jpg

Figure

https://upload.wikimedia.org/wikipedia/commons/b/bc/ Mariner 3 and 4.jpg

Figure

3:

https://en.wikipedia.org/wiki/New_Horizons\#/media/File :New_Horizons_Transparent.png

Figure

4:

https://voyager.jpl.nasa.gov/mission/spacecraft/instrume nts/

Figure

5: https://upload.wikimedia.org/wikipedia/commons/thumb /b/b2/Cassini_Saturn_Orbit_Insertion.jpg/1024px-

Cassini_Saturn_Orbit_Insertion.jpg

Figure

6: https://upload.wikimedia.org/wikipedia/commons/thumb /1/1f/Saturn\%27s_rings_in_visible_light_and_radio.jpg/ 1920px-

Saturn\%27s_rings_in_visible_light_and_radio.jpg 